\title{
Current State and Perspectives on Transesterification of Triglycerides for Biodiesel Production
}

\author{
Mohammed Salaheldeen ${ }^{1}$, Abdalbasit Adam Mariod 2,3 ${ }^{(D}$, Mohamed Kheireddine Aroua ${ }^{4,5}$, \\ S. M. Ashrafur Rahman ${ }^{6}$, Manzoore Elahi M. Soudagar ${ }^{7}$ (D) and I. M. Rizwanul Fattah ${ }^{8, *(D)}$
}

1 Department of Chemistry, Faculty of Education, Nile Valley University, Atbara 46611, Sudan; salahch73@gmail.com

2 College of Science and Art, University of Jeddah, Alkamil 21931, Saudi Arabia; aalnadif@uj.edu.sa

3 Indigenous Knowledge and Heritage Center, Ghibaish College of Science and Technology, Ghibaish, Sudan

4 Research Center for Carbon Dioxide Capture and Utilisation (CCDCU), School of Engineering and Technology, Sunway University, No. 5 Jalan Universiti, Bandar, Sunway, Petaling Jaya 47500, Malaysia; kheireddinea@sunway.edu.my

5 Department of Engineering, Lancaster University, Lancaster LA1 4YW, UK

6 Biofuel Engine Research Facility, Queensland University of Technology, Brisbane, QLD 4000, Australia; rahman.ashrafur.um@gmail.com

7 Department of Mechanical Engineering, School of Technology, Glocal University, Delhi-Yamunotri Marg, SH-57, Mirzapur Pole, Saharanpur 247121, India; me.soudagar@gmail.com

8 Centre for Technology in Water and Wastewater (CTWW), Faculty of Engineering and IT, University of Technology Sydney, Ultimo, NSW 2007, Australia

* Correspondence: IslamMdRizwanul.Fattah@uts.edu.au

Citation: Salaheldeen, M.; Mariod, A.A.; Aroua, M.K.; Rahman, S.M.A.; Soudagar, M.E.M.; Fattah, I.M.R. Current State and Perspectives on Transesterification of Triglycerides for Biodiesel Production. Catalysts 2021, 11, 1121. https://doi.org/10.3390/ catal11091121

Academic Editor: Claudia Carlucci

Received: 9 August 2021

Accepted: 15 September 2021

Published: 18 September 2021

Publisher's Note: MDPI stays neutral with regard to jurisdictional claims in published maps and institutional affiliations.

Copyright: (C) 2021 by the authors. Licensee MDPI, Basel, Switzerland. This article is an open access article distributed under the terms and conditions of the Creative Commons Attribution (CC BY) license (https:/ / creativecommons.org/licenses/by/ $4.0 /)$.
Abstract: Triglycerides are the main constituents of lipids, which are the fatty acids of glycerol Natural organic triglycerides (viz. virgin vegetable oils, recycled cooking oils, and animal fats) are the main sources for biodiesel production. Biodiesel (mono alkyl esters) is the most attractive alternative fuel to diesel, with numerous environmental advantages over petroleum-based fuel. The most practicable method for converting triglycerides to biodiesel with viscosities comparable to diesel fuel is transesterification. Previous research has proven that biodiesel-diesel blends can operate the compression ignition engine without the need for significant modifications. However, the commercialization of biodiesel is still limited due to the high cost of production. In this sense, the transesterification route is a crucial factor in determining the total cost of biodiesel production. Homogenous base-catalyzed transesterification, industrially, is the conventional method to produce biodiesel. However, this method suffers from limitations both environmentally and economically. Although there are review articles on transesterification, most of them focus on a specific type of transesterification process and hence do not provide a comprehensive picture. This paper reviews the latest progress in research on all facets of transesterification technology from reports published by highly-rated scientific journals in the last two decades. The review focuses on the suggested modifications to the conventional method and the most promising innovative technologies. The potentiality of each technology to produce biodiesel from low-quality feedstock is also discussed.

Keywords: triglycerides; biodiesel; esterification; transesterification; biodiesel feedstock

\section{Introduction}

The conversion of renewable energy sources to alternative fuels has been at the forefront of sustainable energy research due to the increased environmental awareness and worries from the expected depletion of fossil fuel resources [1-3]. Biodiesel is among the most promising alternative fuels produced from virgin and waste cooking vegetable oils or animal fats $[4,5]$. Due to its renewability, biodegradability, low emission profile, nontoxicity, and high flash point, biodiesel has a number of advantages over petroleum-based diesel [6-10]. In addition, biodiesel increases the operational lifetime of the compression 
engine and reduces the consumption of the engine spare parts due to the high lubricity of biodiesel $[11,12]$. Therefore, biodiesel is an alternative fuel with the high potentiality to compete with petroleum fuel from environmental and economic points of view $[7,13-15]$. Using vegetable oil as a fuel dates back to the 1900s when Adolf Diesel used peanut oil as fuel in a diesel engine [16,17]. The main problem regarding vegetable oil as fuel is its greater viscosity besides its low volatility and bad cold flow properties, which affect the proper operation of the diesel engine $[18,19]$. The properties of vegetable oils can be improved in different ways, such as pyrolysis, dilution with liquid hydrocarbon (blending), micro emulsification, and transesterification process [20-23]. Transesterification is the most practicable process, among these four ways, for reducing the viscosities of vegetable oils and producing alkyl esters with characteristics comparable to diesel. This is the reason why transesterified vegetable oils are popularized as "biodiesel" [24,25]. Table 1 shows the difference in viscosity between oils and transesterified oils compared to diesel.

Table 1. The effect of transesterification on vegetable oils viscosities [26,27].

\begin{tabular}{ccc}
\hline \multirow{2}{*}{ Fuel Type } & \multicolumn{2}{c}{ Viscosity $\left(\mathbf{m m}^{\mathbf{2}} / \mathbf{s}\right)$ at 311 K } \\
\cline { 2 - 3 } & Raw Oil & Transesterified Oil \\
\hline Sunflower oil & 34.4 & 3.2 \\
Cottonseed oil & 33.0 & 3.1 \\
Rapeseed oil & 37.3 & 3.3 \\
Karanja oil & 38.7 & 4.5 \\
Manilkara zapota oil & 33.8 & 4.7 \\
Diesel fuel no. 2 & & \\
\hline
\end{tabular}

The transesterification reaction modifies one ester to another by changing its alkoxy part [28-30]. This is similar to hydrolysis; however, alcohol is used in this process instead of water and is thus known as alcoholysis [31]. Biodiesel is produced through transesterification by the reaction of lipids with alcohol. The major components of lipids (oil/fats) are triglycerides. Triglycerides are esters of three fatty acids and one glycerol. Thus, the alcoholysis of lipids produces monoalkyl esters, commonly named biodiesel, and glycerol as a by-product. The overall process of transesterification is a sequence of three consecutive and reversible reactions in which di and monoglycerides are formed as intermediates. The stoichiometric reaction requires one mol of triglyceride and three moles of alcohol. However, to maximize the yield of the alkyl ester, alcohol should be used in an excess amount. However, an excessive amount of alcohol makes the separation of the yields difficult. Therefore, the alcohol/oil molar ratio, besides the type of catalyst, temperature, and purity of the reactant, are the factors that affect the process of transesterification [32]. The purity of the reactants, mainly water content and free fatty acids, is the crucial factor that determines the convenient route of transesterification [33,34].

Commonly, the transesterification of lipids is applied by using a short-chain alcohol ( $\mathrm{C} 1$ to $\mathrm{C} 4$ ). However, methanol is the most common alcohol because it is cheaper, and it is easier to recover unreacted methanol. On the other hand, ethyl esters are more renewable because ethanol is produced from agricultural resources [35]. In addition, ethyl esters were proved to have lower emissions of green gases and more biodegradability in the aquatic environment [36,37]. However, there are practical difficulties associated with the production of ethyl esters, as it suffers due to the fast saponification and solubility of ethyl esters in glycerol, which increases at a high oil/ethanol molar ratio [38].

The cost of biodiesel production is high because more than $75 \%$ of its total cost is related to conventional raw materials, such as edible oils and animal fat [39]. On the other hand, using edible vegetable oils for biodiesel production leads to a food crisis [16]. A practical, sustainable transesterification route should produce biodiesel from low-cost feedstocks such as non-edible oils, waste cooking oils, or animal fats, increasing the cost-effectiveness of biodiesel production. Generally, the transesterification process is classified into catalytic and non-catalytic methods. Catalytic methods are categorized into 
homogenous and heterogeneous processes [40]. The transesterification reaction's route determines the biodiesel industry's feasibility, considering economic and environmental constraints. Therefore, this paper aimed to review the progress in research, based on a bench scale, concerning the latest technologies of transesterification. The modifications to the conventional homogenous methods and the most promising innovative catalytic or non-catalytic technologies were critically reviewed.

\section{Homogeneous Catalysis}

\subsection{Homogenous Base-Catalyzed Transesterification}

Basic metal alkoxide, hydroxide, and sodium and potassium carbonates are utilized in the homogeneous base-catalyzed transesterification process [26,41-43]. With virgin vegetable oil, base catalysts typically show high performance with oils containing more free fatty acids than the critical amount to produce soap that inhibits glycerol production and restrains the division of fatty acids to biodiesel and glycerin [44-46]. From an economic point of view, hydroxides are cheap and easy to handle during storage [16]. For continuous biodiesel production, methoxides in methanol are recommended [47]. In both cases, the active species is the methoxide ions resulting from the dissociation of the methoxide salt (Equation (1)) or when methanol reacts with the hydroxide alkaline metal (Equation (2)). The methoxide ions are strong nucleophiles and attack the carbonyl moiety in glyceride molecules to produce alkyl ester [48].

$$
\begin{aligned}
\mathrm{CH}_{3} \mathrm{ONa} & \rightarrow \mathrm{CH}_{3} \mathrm{O}^{-}+\mathrm{Na}^{+} \\
\mathrm{NaOH}+\mathrm{CH}_{3} \mathrm{OH} & \leftrightarrow \mathrm{CH}_{3} \mathrm{O}^{-}+\mathrm{H}_{2} \mathrm{O}+\mathrm{Na}^{+}
\end{aligned}
$$

The comparison of different fundamental catalysts (sodium hydroxide, potassium hydroxide, sodium methoxide, and potassium methoxide) was carried out for methanolysis of sunflower oil by Vicente et al. [49]. The results showed that the biodiesel purity was found to be $100 \mathrm{wt} \%$ for all catalysts. However, $100 \mathrm{wt} \%$ of biodiesel yields were only obtained with the methoxide catalysts. Singh et al. [50] studied the production of biodiesel from canola oil using different homogenous alkaline catalysts and revealed that potassiumbased catalysts give a better yield than sodium-based catalysts, and methoxide catalysts give higher yields than corresponding hydroxide catalysts as follows: $\mathrm{KOCH}_{3}>\mathrm{NaOCH}_{3}>$ $\mathrm{KOH}>\mathrm{NaOH}$. Biodiesel purities (i.e., methyl ester concentration in the biodiesel) reported for $\mathrm{NaOH}, \mathrm{KOH}, \mathrm{NaOCH}_{3}$, and $\mathrm{KOCH}_{3}$ were $99.70 \pm 0.04(\%), 99.76 \pm 0.05(\%), 99.73 \pm$ $0.03(\%)$, and $99.52 \pm 0.1(\%)$, respectively. Biodiesel yield (i.e., the relative amount of the methyl ester to the oil) reported for $\mathrm{NaOH}, \mathrm{KOH}, \mathrm{NaOCH}_{3}$, and $\mathrm{KOCH}_{3}$ were $86.71 \pm 0.28$ (\%), $91.67 \pm 0.27(\%), 99.33 \pm 0.36(\%)$, and $98.46 \pm 0.16(\%)$, respectively.

Industrial processes favor base catalysts for biodiesel production because they are less corrosive and produce biodiesel with high purity and yields in a short time compared to acid catalysts $[51,52]$. However, homogenous base catalysts are not tolerant to the free fatty acids (FFAs) in the feedstock with high concentrations. Feedstock has to comply with strict specifications. In particular, the total (FFAs) content must not exceed $0.5 \mathrm{wt} \%$ of oil. Otherwise, the catalyst is consumed due to the formation of soaps, as indicated in (Equation (3)). The base method is not suitable for feedstocks with high FFAs content, such as some non-edible vegetable oils, waste cooking vegetable oils, or animal fats. Further, alcohol and the catalyst must be essentially anhydrous because the water in the feedstocks promotes hydrolysis of alkyl esters to FFAs (Equation (4)) and, consequently, soap formation. Soap formation makes the separation of glycerol from alkyl ester complex [53]. From an environmental point of view, homogenous catalysis by alkali-hydroxides produces a large amount of wastewater discharged from the process to wash the dissolved catalyst off the produced biodiesel [54,55].

$$
\begin{gathered}
\mathrm{RCOOH}+\mathrm{NaOH} \text { or }\left(\mathrm{CH}_{3} \mathrm{ONa}\right) \rightarrow \mathrm{RCOONa}+\mathrm{H}_{2} \mathrm{O} \text { or }\left(\mathrm{CH}_{3} \mathrm{OH}\right) \\
\mathrm{RCOOCH}_{3}+\mathrm{H}_{2} \mathrm{O} \leftrightarrow \mathrm{RCOOH}+\mathrm{CH}_{3} \mathrm{OH}
\end{gathered}
$$


The fast saponification accompanying the production of ethyl esters by alkali base catalysts could be avoided by developing a process consisting of two reactions steps with glycerin separation and the addition of ethanol/alkali in each of them. A $99 \%$ conversion of sunflower oil to fatty acid ethyl ester by Mendow et al. [38] was achieved with low total consumption of ethanol during the whole process. The optimal reaction temperature was $55^{\circ} \mathrm{C}$ at an ethanol/oil total molar ratio of 4.25:1. Sodium methoxide catalyst total concentration was $1.06 \mathrm{~g}$ catalyst $/ 100 \mathrm{~g}$ oil; $50 \%$ of the catalyst was added in each reaction step. This two-stage alkali-catalyzed transesterification deserves to be industrially considered since biodiesel with required standard total glycerin content and low consumption of alcohol and catalyst, besides a higher biodiesel yield compared to one-stage transesterification, could be achieved.

\subsection{Homogenous Acid-Catalyzed Transesterification}

This method of production is the second conventional route to produce biodiesel. Sulfuric acid and sulphonic acids are most commonly used [56-58]. This type of catalyst gives very high yields in alkyl esters. However, it is industrially ignored, despite the advantage of its insensitivity to the presence of FFAs in the feedstock, because of its low reaction rate and requiring large quantities of alcohol $[59,60]$. The reaction kinetics of acidcatalyzed transesterification of waste frying oil was investigated by Zheng et al. [61]. They proved that the fatty acid methyl ester yield depended significantly on the temperature and the molar ratios between oil, methanol, and the acid catalyst. The transesterification reaction was a pseudo-first-order reaction because the maximum yield $(99 \pm 1 \%)$ was obtained using extensive methanol access.

The effect of the methanol:oil molar ratios on the acid-catalyzed transesterification of soybean oil was studied by Fredman et al. [62] by using ( $1 \mathrm{wt} \%)$ concentrated sulfuric acid based on the oil weight at a temperature near the boiling point of methanol. They had conducted preliminary experiments with 6:1 and 20:1 molar ratios at 3 and $18 \mathrm{~h}$, respectively. The conversion to esters was not satisfactory. However, a molar ratio of 30:1 resulted in a higher conversion to methyl ester after $69 \mathrm{~h}$. The effect of the temperature on the methylation of crude palm oil was investigated by Crabbe et al. [63] at 75, 80, and $95^{\circ} \mathrm{C}$ using $5 \%$ sulfuric acid and a 40:1 molar ratio methanol to the oil over $24 \mathrm{~h}$. Biodiesel yield $\left(99.7 \mathrm{wt} \%\right.$ ) was obtained at $95^{\circ} \mathrm{C}$ after $9 \mathrm{~h}$, while a similar yield was obtained at $80^{\circ} \mathrm{C}$ after $24 \mathrm{~h}$. Methylation at $75^{\circ} \mathrm{C}$ was slow and incomplete, even after $24 \mathrm{~h}$. Considering temperature, acid-catalyzed transesterification is energy-intensive.

Acids can catalyze both esterification and transesterification reactions by protonation of the fatty acids and triglycerides [59]. Hence, because acids can simultaneously catalyze both esterification and transesterification reactions, the acid-catalyzed method is suitable for producing biodiesel from low-cost feedstock with high FFAs content. From this point, acid-catalyzed production of biodiesel can compete economically with the base-catalyzed process [53]. According to a techno-economical assessment [64,65], an acid-catalyzed process using waste cooking oil was proved feasible with less complexity in equipment and more economical than the alkali-catalyzed process using waste cooking oil. This is because the alkali-catalyzed process requires an additional pretreatment unit for the FFAs removal.

\subsection{Acid-Base Catalyzed Two-Step Process}

This process is suitable for the production of biodiesel from feedstocks with high (FFAs). The first step is acid-catalyzed pretreatment to esterify FFAs to reduce their content to less than $1 \mathrm{wt} \%$. The second step is transesterifying the triglycerides with an alkaline catalyst to complete the reaction [66-69]. Charoenchaitrakool and Thienmethangkoon [70] applied the two-step catalyzed pretreatment process to convert waste frying vegetable oil to biodiesel. The methyl ester content in the product was $90.56 \pm 28 \%$. The optimum conditions in the first step to reducing the FFAs to less than $0.5 \mathrm{wt} \%$ were $6.1: 1$ methanol/oil 
ratio, $0.68 \mathrm{wt} \%$ of $\mathrm{H}_{2} \mathrm{SO}_{4}$, at $51{ }^{\circ} \mathrm{C}$ and $60 \mathrm{~min}$ of reaction time. The second step consumed $1 \mathrm{wt} \% \mathrm{KOH}$ with a methanol/oil ratio $9.1: 1$ at $55^{\circ} \mathrm{C}$ and $60 \mathrm{~min}$.

Ghadge and Raheman [71] reduced the FFAs content of mahua oil (Madhuca indica) from $19 \%$ to less than $1 \%$ through a two-step pretreatment process prior to alkaline catalyzed transesterification. They proved that FFAs content is influenced by both quantities of methanol and reaction time. It was apparent that a high amount of methanol was consumed during the two steps of pretreatment. To make this process feasible in a commercial application, part of methanol should be recovered from the water mix that is separated from the top after each step.

A novel homogenous catalysis route is present to produce biodiesel from feedstock with high FFAs in one step by using acidic ionic liquids (ILs) [72,73]. Although ionic liquids are costlier than regular catalysts, such as $\mathrm{NaOH}, \mathrm{KOH}$, and $\mathrm{H}_{2} \mathrm{SO}_{4}$, they offer advantages of reusability and biodegradability. Metal chlorides (MCln) were found to significantly increase the catalytic activity of acidic ILs to catalyze the esterification and transesterification reactions simultaneously. A maximum biodiesel yield of $99.7 \%$ was achieved from un-pretreated Jatropha with high FFAs (13.8 mgKOH/g) by adding a mixture of $\mathrm{FeCl}_{3}$ and 1-butyl-3 methyl imidazolium-tosylate ([BMIm] $\left[\mathrm{CH}_{3} \mathrm{SO}_{3}\right]$ ); a Brønsted acidic ILs. However, from an economic point of view, ILs with metal chlorides need advancement in the techniques to compete for the conventional solvents and catalysts in the large-scale production of biodiesel [74]. Choline hydroxide $(\mathrm{ChOH})$ was employed as a green ionic liquid catalyst by Phromphithak et al. [75] to produce biodiesel from palm oil. A maximum biodiesel yield of $89.72 \%$ methyl ester content was obtained at 1:13.24 oil to methanol molar ratio, a flow rate of $20 \mathrm{~mL} / \mathrm{min}$, microwave power of $800 \mathrm{~W}$, and catalyst loading of $6 \%(w / w)$.

\subsection{Transesterification Double Step Process (TDSP)}

This method is found to be very effective in the separation of the biodiesel/glycerin phase. The first step is basic catalyzed transesterification, followed by the addition of an acidic catalyst. The addition of the acid in the second step breaks the soaps and catalyzes the reaction simultaneously. The overall process is swift and yields high purity due to the high conversion degree [53,76,77]. Samios et al. [77] produced biodiesel with high quality and purity, as indicated by ${ }^{1} \mathrm{H}-\mathrm{NMR}$, from sunflower and linseed oils using the TDSP. The evaluation of the ${ }^{1} \mathrm{H}$-NMR data suggested that the oil conversion degree to fatty acid methyl ester was higher than $97 \%$. Hydroxyl vegetable oil, such as castor oil, has a high solubility in ethanol and glycerin. Therefore, the ethanolysis of such vegetable oils by the conventional basic catalyst is not feasible. MontesD'Oca et al. [76] demonstrated that using the TDSP was necessary to improve the separation of glycerin and fatty acid ethyl ester produced from the transesterification of castor oil. They achieved high ethyl esters yields, glycerin with high purity $(95.76 \%)$, and free and bound glycerol was less than the specified value. A modified TDSP was used to ethanolyze some vegetable oils and waste vegetable oils by Gazatto et al. [78]. The triglyceride conversion to biodiesel was higher than $97 \%$ for all oil used, and the yields were considerably high compared to single basic catalysis yields. TDSP is evaluated as a new method for biodiesel production with higher conversion than the basic one and sufficiently smaller operational time than acid catalysis. However, this method needs more investigations to be industrially competitive [77].

\section{Heterogeneous Catalysis}

The heterogeneous catalytic process seems to be an appropriate solution to overcome all problems associated with homogenous catalysts. The use of heterogeneous catalysts is currently preferred due to the main advantages of: (1) quickly separation and purification of final products, (2) it can be regenerated and recycled, and (3) it could be operated in continuous processes with no need for acid or water treatment in the separation step, so it is environmentally benign $[79,80]$. For all these advantages, heterogeneous catalysis has strongly drawn the attention of researchers. Heterogeneous catalysts can be solid base or solid acid [80]. The main mechanism of heterogeneous catalysis follows the principle 
of homogeneous catalysis of either base or acid systems similarly [81]. In most cases, the solid catalyst is prepared by the impregnation of active compounds into the surface of porous material [82]. This method increases the catalytic activity and decreases the catalyst required during the transesterification process [83].

\subsection{Heterogeneous Base-Catalyzed Process}

Table 2 shows the conversion rate of some vegetable oils to biodiesel and optimized conditions using a solid base catalyst. Transesterification of soybean oil with a $\mathrm{CaO} /$ mesoporous silica catalyst was achieved by Samart et al. [83]. The optimized condition for the highest yield (95.2\%), found to be $15 \mathrm{wt} \%$ of Ca loading on the mesoporous silica catalyst, was a $5 \%(w / w)$ catalyst to oil level, and reaction temperature of $60{ }^{\circ} \mathrm{C}$ for $8 \mathrm{~h}$. Zeolites, such as MCM-41 and SBA-15, are considered promising support for various metals due to their catalytic surface properties and thermal stability. However, this support has a weak acidity due to the localized non-polar silanol groups on the pore walls. Liang et al. [84] impregnated Na precursor salts into SBA-15 and increased the surface acidity of the resultant catalyst (Na/SBA-15) by incorporating heteroatom Al. They used the modified catalyst (Na/Al SBA-15) to transestrify canola oil, 99\% conversion to biodiesel was achieved at the optimum condition of $6: 1$ methanol to oil molar ratio, $65{ }^{\circ} \mathrm{C}$ temperature, and $6 \mathrm{~h}$ reaction time. The metal loading weight was 5\%. Chen et al. [85] incorporated $\mathrm{Zr}$ atoms into the SBA-15 structure, facilitating the formation of Brönsted acid sites and decreasing the particle size of $\mathrm{Na}$ species. Catalysts with a higher $\mathrm{Zr}$ content enhanced the fatty acid methyl ester (FAME) yield as 99\% were obtained at a 6:1 methanol/oil molar ratio, $12 \%$ catalyst content ( $\mathrm{wt} \%$ oil) with $15 \mathrm{wt} \% \mathrm{Na}$ loaded into the support, reaction temperature of $70{ }^{\circ} \mathrm{C}$, and a reaction time of $6 \mathrm{~h}$.

Table 2. Solid basic catalysts for biodiesel production.

\begin{tabular}{|c|c|c|c|c|c|c|c|}
\hline \multirow[b]{2}{*}{ Catalyst } & \multirow{2}{*}{$\begin{array}{l}\text { Catalyst to Oil } \\
\quad \%(w / w)\end{array}$} & \multirow[b]{2}{*}{ Feedstock } & \multirow[b]{2}{*}{ Conversion $\%$} & \multicolumn{3}{|c|}{ Reaction Parameters } & \multirow[b]{2}{*}{ Reference } \\
\hline & & & & $\begin{array}{l}\text { Methanol to Oil } \\
\text { Molar Ratio }\end{array}$ & $\begin{array}{c}\text { Reaction Time } \\
\mathrm{h}\end{array}$ & $\begin{array}{c}\text { Temperature } \\
{ }^{\circ} \mathrm{C}\end{array}$ & \\
\hline $\begin{array}{l}\mathrm{CaO} / \text { Mesoporous } \\
\text { silica }\end{array}$ & 5 & Soybean oil & 95.2 & $16: 1$ & 8 & 60 & [83] \\
\hline $\mathrm{CaSn}(\mathrm{OH})_{6}$ & 3 & $\begin{array}{l}\text { Oils with high } \\
\text { free fatty acids }\end{array}$ & $92-96$ & 10:1 & $3-14$ & 65 & [86] \\
\hline $\mathrm{Na} / \mathrm{Al}-\mathrm{SBA}-15$ & 3 & Canola oil & 99 & $6: 1$ & 6 & 65 & [84] \\
\hline $\mathrm{Na} / \mathrm{Zr}-\mathrm{SBA}-15$ & NA & Canola oil & 99 & $6: 1$ & 6 & 70 & [85] \\
\hline$\left(\mathrm{BaAl}_{2} \mathrm{O}_{4}\right)$ & 12 & $\begin{array}{l}\text { Used cooking } \\
\text { oil }\end{array}$ & 93.28 & $21: 1$ & 2.5 & 65 & [87] \\
\hline$(\mathrm{f}-\mathrm{MgO})$ & NA & Canola oil & 93.4 & $16: 1$ & 2.5 & 190 & [88] \\
\hline
\end{tabular}

Sandesh et al. [86] studied the transesterification of both edible and non-edible oils, such as sunflower, waste cooking oil, Jatropha, honge, and simarouba oils, using calcium hydroxy stannate $\left(\mathrm{CaSn}(\mathrm{OH})_{6}\right)$ as a strong heterogeneous solid base catalyst. Esterification of oils with an acid value greater than two was carried out first. The results showed that $\mathrm{CaSn}(\mathrm{OH})_{6}$ showed varying performance for different studied oils with $>90 \%$ biodiesel yield with $3 \mathrm{wt} \%$ catalysts. The oil to methanol ratio was 1:10, and the reaction temperature was kept at $65^{\circ} \mathrm{C}$. Yadav and Sharma [87] studied the transesterification of used vegetable oil using a heterogeneous base catalyst, barium aluminate $\left(\mathrm{BaAl}_{2} \mathrm{O}_{4}\right)$, which was synthesized by the co-precipitation route. A 93.28\% conversion of methyl ester was obtained at a methanol to oil molar ratio of $21: 1$, catalyst amount $4 \mathrm{wt} \%$, reaction temperature of $65 \pm 0.5^{\circ} \mathrm{C}$, for a $150 \mathrm{~min}$ reaction duration. Lee et al. [88] studied the canola oil biodiesel conversion using hierarchical flower-shaped hollow $\mathrm{MgO}$ (f-MgO) spheres as heterogeneous catalysts. Flower-like $\mathrm{MgO}$ nanostructures based on ultrathin petal-like nanosheets led to superior catalytic activity over commercial $\mathrm{MgO}$. The experimental results for the 
fatty acid methyl ester revealed that the maximum biodiesel conversion efficiency of f-MgO from canola oil is $93.4 \%$.

\subsection{Heterogeneous Acid-Catalyzed Process}

Heterogeneous acid catalysts have a less corrosive and toxic effect and give rise to fewer environmental problems compared to homogeneous acid catalysts [52]. Singleprocess simultaneous esterification and transesterification of non-edible oils with high FFAs using solid acid catalysts have emerged as an alternative method to the more complex homogenous two-step (acid-base) process [81]. Transesterification of refined and crude vegetable oils was carried out with a sulphonic acid-modified meso-structural catalyst. Regardless of the presence of free fatty acid, this catalyst showed high activity towards simultaneous esterification and transesterification reactions [89]. Malins et al. [90] compared the esterification reactions of rapeseed oil fatty acids (RFA) and RFA/rapeseed oil (RO) mixture (weight ratio 1/2) using 4-sulfophenyl activated carbon-based solid acid catalyst $\left(\mathrm{ACPhSO}_{3} \mathrm{H}\right)$ and Amberlyst-15 (an industrial-grade solid acid catalyst). Esterification was carried out under the molar ratio of RFA to methanol $(1 / 20)$, reaction time $(0-7 \mathrm{~h})$ at $65^{\circ} \mathrm{C}$. $\mathrm{ACPhSO}_{3} \mathrm{H}$ catalyzed the conversion of RFA to RME using pure RFA, and the RFA/RO mixture was $\sim 95 \%$ and $\sim 92 \%$ after $7 \mathrm{~h}$ of reaction, respectively. For pure RFA using Amberlyst-15, the final conversion was similar, with a higher initial conversion of $\sim 6-9 \%$ in the first $\sim 4 \mathrm{~h}$. However, for RFA/RO mixture, a conversion of $\sim 96 \%$ was obtained in the presence of Amberlyst-15, which was $4.5 \%$ higher than that obtained with $\mathrm{ACPhSO}_{3} \mathrm{H}$ as the catalyst. They attributed the higher conversion of Amberlyst- 15 to the higher $\mathrm{PhSO}_{3} \mathrm{H}$ density in comparison with $\mathrm{ACPhSO}_{3} \mathrm{H}$. Bhatia et al. [91] studied the transesterification of waste canola oil-based cooking oil using heterogeneous acidic biochar catalyst prepared by pyrolysis of waste cork (Quercus suber). The maximum fatty acids methyl esters (FAMEs) conversion of $98 \%$ was obtained for the catalyst (pyrolyzed cork at $600{ }^{\circ} \mathrm{C}$ ) with alcohol:oil (25:1), catalyst loading $(1.5 \% \mathrm{w} / \mathrm{v})$, and a temperature of $65^{\circ} \mathrm{C}$. Table 3 presents some novel heterogeneous solid acid catalysts for the production of biodiesel from the low-quality feedstock.

Lately, the single-step solid acid process has mainly been ignored mainly because of its relatively slower reaction rate [64,92]. Wang et al. [93] have developed a two-step catalyzed process (solid acid/alkaline base) to produce biodiesel from waste cooking oil. This process was presented as an industrial technique that is more feasible compared to the traditional homogenous acid-catalyzed process. The first step was the esterification of the FFAs with ferric sulfate. The second step was transesterification of the oil with potassium hydroxide. This new two-step catalyzed process has the advantages of no wastewater, reusable catalyst, and low cost of reaction tank. They reported that with a 20:1 molar ratio of $\mathrm{H}_{2} \mathrm{SO}_{4}$ and $10 \mathrm{~h}$ reaction time, the biodiesel yield was $90 \mathrm{wt} \%$, whereas, for $\mathrm{Fe}_{2} \mathrm{O}_{3} / \mathrm{KOH}, 97.22 \mathrm{wt} \%$ biodiesel yield was obtained with 10:1 molar ratio of catalyst and $4 \mathrm{~h}$ reaction time. Zhang et al. [94] have proven that biodiesel can be produced successfully from Zanthoxylum bungeanum seed oil with high FFAs through ferric sulfate-catalyzed esterification followed by transesterification using $\mathrm{CaO}$ as the alkaline catalyst. The acid value of the oil was reduced to less than $2 \mathrm{mg} \mathrm{KOH} / \mathrm{g}$ from $41.02 \mathrm{mg} \mathrm{KOH} / \mathrm{g}$ by the esterification process under the conditions of methanol-to-FFA molar ratio 40.91:1, ferric sulfate $9.75 \mathrm{wt} \%$ (of FFA), reaction temperature $95^{\circ} \mathrm{C}$, and reaction time $2 \mathrm{~h}$. Transesterification of esterified oil was later carried out using $\mathrm{CaO}$ as a catalyst at optimized conditions with a methanol-to-oil molar ratio 11.69:1, catalyst amount $2.52 \mathrm{wt} \%$, and reaction time $2.45 \mathrm{~h}$, which resulted in a conversion to biodiesel above $96 \%$.

Recently, new types of solid catalysts that have both acidic and basic sites on their surface have been investigated intensively. This type of catalyst, called acid-base bifunctional catalysts, can utilize the low feedstock with high FFAs for biodiesel production due to their efficient catalytic activity to esterify FFAs and transesterification of the triglycerides in the oil, simultaneously in one step. Moreover, these catalysts are insensitive to water present in the feedstock or produced during the reaction of esterification [95]. A novel and robust 
calcium-boron solid bifunctional catalyst was prepared by sol-gel methods and calcined at $700{ }^{\circ} \mathrm{C}$. The developed catalyst showed a smooth rod-like structure, proper surface area, identical pore size, and concentrated acid-base sites. A $4 \mathrm{wt} \%$ of this catalyst at $105^{\circ} \mathrm{C}$ and 20:1 methanol to oil molar ration successfully converted Jatropha oil with high FFAs (9.2 $\mathrm{mg} \mathrm{KOH} / \mathrm{g}$ ) to biodiesel with a yield of $96 \%$ after only $2 \mathrm{~h}$ of reaction time. Ca-B exhibited high stability and reusability up to five cycles [96]. A bifunctional solid acid-base catalyst composed of $\mathrm{CaO}$ and $\mathrm{La}_{2} \mathrm{O}_{3}$, prepared by co-precipitation methods, was used to produce biodiesel from Jatropha oil with high FFAs. A high biodiesel yield $(98.76 \%)$ was achieved under transesterification conditions of $160{ }^{\circ} \mathrm{C}, 3 \mathrm{~h}, 25$ methanol/oil molar ratio, and 3 $\mathrm{wt} \%$ catalyst. A Ca-La catalyst was used without much deterioration for four consecutive cycles [97]. Graphene Oxide-Alumina composite has been synthesized by a self-limiting hydrogel procedure and used for simultaneous esterification of FFAs and triglycerides in sunflower oil. The developed bifunctional catalysts exhibited superior acidic-basic properties. The composite with $5 \mathrm{wt} \% \mathrm{GO}$ loading gave, after $10 \mathrm{~h}$, oil conversion of $85.2 \%$ by using only $1.0 \mathrm{wt} \%$ catalyst to oil at $60{ }^{\circ} \mathrm{C}$ and $30: 1$ methanol to oil molar ratio, in a traditional batch reactor. Moreover, the same composite (GO (5 wt\%)-alumina) gave higher oil conversion $(97 \%)$ to methyl esters in an autoclave reactor at $120{ }^{\circ} \mathrm{C}$. In addition, the same catalyst exhibited tolerance to water content up to $3 \mathrm{wt} \%$ and reusability six times [98].

Table 3. Some novel heterogeneous solid acid catalysts for the production of biodiesel from the low-quality feedstocks.

\begin{tabular}{|c|c|c|c|c|c|c|}
\hline \multirow{2}{*}{ Catalyst } & \multirow{2}{*}{ Feedstock } & \multicolumn{2}{|c|}{ Acid Value (mgKOH/g) } & \multirow{2}{*}{ Reaction Time } & \multirow{2}{*}{$\begin{array}{c}\text { Biodiesel Yield } \\
\text { wt } \%\end{array}$} & \multirow{2}{*}{ Reference } \\
\hline & & Initial Value & Final Value & & & \\
\hline $\mathrm{Fe}_{2} \mathrm{O}_{3} / \mathrm{KOH}$ & Waste cooking oil & 75.92 & - & - & 97.22 & [93] \\
\hline $\mathrm{Fe}_{2} \mathrm{O}_{3} / \mathrm{CaO}$ & $\begin{array}{c}\text { Zanthoxylum } \\
\text { bungeanum }\end{array}$ & 41.02 & 2 & 4.45 & 96 & [94] \\
\hline Ca-B & Jatropha oil & 9.2 & 0.5 & 2 & 96 & [96] \\
\hline $\mathrm{Ca}-\mathrm{La}$ & Jatropha oil & $16.03-22.85$ & 0.5 & 3 & 98.76 & [97] \\
\hline $\begin{array}{c}\text { Graphene } \\
\text { Oxide- }(5 \mathrm{wt} \%) \\
\text { Alumina }\end{array}$ & $\begin{array}{l}\text { Waste sunflower } \\
\quad \text { oil }\end{array}$ & NA & NA & 10 & 97 & [98] \\
\hline $\begin{array}{c}\text { Fly ash } \\
\left(\mathrm{CaO} / \mathrm{SO}_{3}\right)\end{array}$ & Waste frying oil & 6.35 & NA & 9 & 81.96 & [99] \\
\hline
\end{tabular}

Fly ash that had a high content of $\mathrm{CaO}(47 \mathrm{wt} \%)$ and $\mathrm{SO}_{3}(27 \mathrm{wt} \%)$ was used to produce biodiesel from waste frying oil in one step. A high yield of biodiesel $(81.96 \%)$ was obtained after a $9 \mathrm{~h}$ reaction time by using $5 \mathrm{wt} \%$ fly ash and a $6: 1$ molar ratio methanol to oil at $45{ }^{\circ} \mathrm{C}$ reaction temperature. $\mathrm{SO}_{3} \mathrm{H}$ group catalyzes the esterification of the FFAs, and $\mathrm{CaO}$ catalyzes the transesterification of the triglycerides in the raw material, and the two processes occur simultaneously [99].

\subsubsection{The Role of Co-Solvent in Heterogeneous Catalyst}

One of the significant problems associated with heterogeneous catalysis is the slow reaction rate due to forming a three-phase system, which inhibits the reaction [100]. Using a certain amount of a co-solvent, such as tetrahydrofuran (THF), dimethylsulfoxide (DMSO), and n-hexane, is found to be a practical solution to increase the miscibility of oil and methanol and accordingly accelerate the reaction rate [101,102]. Using n-hexane as a co-solvent in the transesterification of soybean oil by $\mathrm{Na} / \mathrm{NaOH} / \gamma \mathrm{Al}_{2} \mathrm{O}_{3}$ base heterogeneous catalyst was adopted with a 5:1 oil n-hexane molar ratio [103]. Lam and Lee [104] demonstrated that biodiesel could be an effective co-solvent to accelerate the transesterification reaction catalyzed by a solid acid catalyst $\left(\mathrm{SO}_{4}^{2-} / \mathrm{SnO}_{2}-\mathrm{SiO}_{2}\right)$. Fatty acid methyl ester yield was 30\% higher than without using a co-solvent in short reaction times. Biodiesel, according to this study, is considered to be a better co-solvent than THF or n-hexane because it is not required to be separated from the product mixture. Gargari 
and Sadrameli [105] studied the continuous transesterification of linseed oil in a packed bed reactor using $\mathrm{CaO}$ as a heterogeneous catalyst and diethyl ether (DEE) as a co-solvent. DEE plays a crucial role in the high yield of FAMEs as a continuous method is restricted by the absence of an appropriate agitator to disperse the oil and methanol during the reaction. Under optimal conditions of a molar ratio of DEE to methanol of 1.19:1, a molar ratio of methanol to oil of $9.48: 1$, and a flow rate of $1.37 \mathrm{~mL} / \mathrm{min}$, a FAMEs yield of $98.08 \%$ was achieved compared to $75.83 \%$ in the absence of DEE. Hájek et al. [106] studied the use of methanol together with butanol in the transesterification of rapeseed oil under heterogeneous catalysis. Mg-Fe mixed oxide with a molar ratio $\mathrm{Mg} / \mathrm{Fe}$ of 3:1 was used as a heterogeneous catalyst. Transesterification was carried out at a constant 24:1 molar ratio of total alcohols to oil with various molar ratios between methanol and butanol, $1 \mathrm{wt} \%$ of catalyst to input rapeseed oil and $120^{\circ} \mathrm{C}$ reaction temperature. The content of esters in the ester phase reached $97.5 \mathrm{wt} \%$ after $4 \mathrm{~h}$. They showed that the addition of butanol caused a higher yield than for methanol or butanol only.

\subsubsection{Nano-Heterogeneous Catalysis}

Nanotechnology enables scientists to manipulate and produce new materials with specific physicochemical characteristics [107-109]. Hence, a new promising method to overcome the challenge of mass transfer depends on nanotechnology. The tremendous surface area on nanomaterials increases the reaction area and the active center extraordinarily and leads to catalytic reactions, a highly efficient and time-saving process. $\mathrm{KF} / \mathrm{CaO}$ nano-catalyst (particle size $30-100 \mathrm{~nm}$ and average pore size $97 \mathrm{~nm}$ ) was prepared by the impregnation method and used to convert Chinese tallow oil to biodiesel, a 96.8\% yield was obtained at the optimized condition molar ratio 12:1 of alcohol to oil, the catalyst was $4 \% w / w$ of the oil, the reaction temperature was $65^{\circ} \mathrm{C}$, and reaction time was $2.5 \mathrm{~h}$. The high catalytic ability was attributed to the formation of the new crystal $\mathrm{KCaF}_{3}$, as indicated by $X$-ray diffractometer (XRD) analysis. The active anion $\mathrm{CH}_{3} \mathrm{O}^{-}$is more easily released in the reaction media by $\mathrm{KCaF}_{3}$ than $\mathrm{CaO}$ is due to the stronger Lewis $\mathrm{F}^{-}$and stronger Lewis $\mathrm{Ca}^{2+}$. These two species work simultaneously to deprotonate $\mathrm{CH}_{3} \mathrm{OH}$ and attract the released $\mathrm{CH}_{3} \mathrm{O}^{-}$. In addition, the resultant crystal phase renders the $\mathrm{KF} / \mathrm{CaO}$ nano-catalyst more stable than the $\mathrm{CaO}$ catalyst, considering the leaching effect and reusability. The biodiesel yield was over $91 \%$ even after 16 cycles. Moreover, the solid base nano-catalyst KF/CaO showed good anti-acid ability and more acidic tolerance than $\mathrm{Ca} / \mathrm{Mg}$ catalysts [110]. In an attempt to increase the basicity and the catalytic activity of $\mathrm{CaO}$, Degirmenbasi et al. [111] impregnated nanoparticles of $\mathrm{CaO}$ on $\mathrm{K}_{2} \mathrm{CO}_{3}$ at $773 \mathrm{~K}$ calcination temperature. A $3 \mathrm{wt} \%$ to canola oil of the resultant catalyst $\left(\mathrm{K}_{2} \mathrm{CO}_{3}(7 \%) /\right.$ nano $\left.\mathrm{CaO}\right)$ efficiently enhanced the transesterification of the triglycerides in canola oil, and the biodiesel yield reached $97.67 \% \pm 1.7$ in $8 \mathrm{~h}$ of reaction time in a liquid batch reactor, at $338 \mathrm{~K}$ and a 9:1 methanol to oil molar ratio. The yield of methyl ester was only $60.33 \% \pm 2.9$ for pure $\mathrm{CaO}$. The basic degree of the functionalized Nano $\mathrm{CaO}$ catalyst did not decrease significantly and maintained its catalytic activity for five consecutive cycles.

Calcium aluminate nano-catalyst was prepared by using the novel method of microwave combustion. Impregnation of $23 \mathrm{wt} \% \mathrm{KOH}$ to $\mathrm{CaO}-\mathrm{Al}_{2} \mathrm{O}_{3}$ tremendously increased the catalytic activity of this catalyst towards the transesterification of canola oil. A high yield of biodiesel $(96.7 \%)$ was obtained at the optimal condition of $65^{\circ} \mathrm{C}, 3.5 \mathrm{wt} \%$ catalyst, 12:1 molar ratio of methanol-to-oil, and $4 \mathrm{~h}$ reaction time. $\mathrm{KOH} /$ calcium aluminate nano-catalyst was efficient for catalyzing the transesterification reaction at least three times.

Nano-magnetic catalysts have high catalytic activity and have the advantages of easy separation and recovery [112]. $\mathrm{CaO}$ was encapsulated on a magnetic core of $\gamma \mathrm{Fe}_{2} \mathrm{O}_{3}$ based on the sol-gel method using $\mathrm{KNO}_{3}$. The obtained magnetic catalyst $\mathrm{CaO} @ \gamma \mathrm{Fe}_{2} \mathrm{O}_{3}$ performed high catalytic activity in the transesterification of soybean oil and produced $98.8 \%$ biodiesel yield at optimal parameters of catalyst dosage $2.0 \mathrm{wt} \%$, the ratio of methanol and soybean oil 15:1, reaction temperature $70^{\circ} \mathrm{C}$, and reaction time $3 \mathrm{~h}$. Moreover, magnetic catalyst $\mathrm{CaO} @ \gamma \mathrm{Fe}_{2} \mathrm{O}_{3}$ showed high resistance to FFAs compared to pure $\mathrm{CaO}$ and high 
reusability (4 times) [113]. A nano-magnetic solid base catalyst $\mathrm{KF} / \mathrm{CaO}-\mathrm{Fe}_{3} \mathrm{O}_{4}$ was synthesized by a facile impregnation method and used in the transesterification of Chinese tallow oil with over $95 \%$ biodiesel yield. Due to the magnetic separation, the catalyst recovery was more than $90 \%$, and the catalyst was able to be reused up to 14 times without much deterioration in its activity [114]. Table 4 summarizes some novel nano-heterogeneous-based catalysts for biodiesel production.

Table 4. Some novel nano-heterogeneous-based catalysts for biodiesel production.

\begin{tabular}{|c|c|c|c|c|c|c|c|c|c|}
\hline \multirow[b]{2}{*}{ Catalyst } & \multirow[b]{2}{*}{$\begin{array}{l}\text { Method of } \\
\text { Preparation }\end{array}$} & \multirow[b]{2}{*}{$\begin{array}{l}\text { FeedStock } \\
\quad \text { (oil) }\end{array}$} & \multicolumn{4}{|c|}{ Reaction Parameters } & \multirow[b]{2}{*}{$\begin{array}{c}\text { Conversion } \\
\text { or Yield } \\
\text { wt } \%\end{array}$} & \multirow[b]{2}{*}{ Reusability } & \multirow[b]{2}{*}{ Ref. } \\
\hline & & & $\begin{array}{l}\text { Catalyst } \\
\text { Loading } \\
\text { wt } \%\end{array}$ & $\begin{array}{l}\text { Methanol to Oil } \\
\text { Molar Ratio }\end{array}$ & $\begin{array}{l}\text { Temperature } \\
{ }^{\circ} \mathrm{C}\end{array}$ & $\underset{\mathrm{h}}{\mathrm{Time}}$ & & & \\
\hline $\mathrm{KF} / \mathrm{CaO}$ & Impregnation & $\begin{array}{l}\text { tallow seed } \\
\quad \text { oil }\end{array}$ & 4 & $12: 1$ & 65 & 2.5 & 96.8 & 16 & [110] \\
\hline $\begin{array}{c}\left(\mathrm{K}_{2} \mathrm{CO}_{3}(7 \%) / \text { nano }\right. \\
\mathrm{CaO}\end{array}$ & Impregnation & canola oil & 3 & $9: 1$ & 115 & 8 & $97.67 \% \pm 1.7$ & 5 & [111] \\
\hline $\begin{array}{c}\mathrm{KOH}(23 \\
\text { wt } \%) / \text { Calcium } \\
\text { aluminate } \\
\text { nano-catalyst }\end{array}$ & $\begin{array}{l}\text { Microwave combus- } \\
\text { tion/impregnation }\end{array}$ & $96.7 \%$ & 3.5 & $12: 1$ & 65 & 4 & $96.7 \%$ & 3 & [112] \\
\hline $\mathrm{CaO} @ \gamma-\mathrm{Fe}_{2} \mathrm{O}_{3}$ & $\begin{array}{c}\mathrm{CaO} @ \gamma- \\
\mathrm{Fe}_{2} \mathrm{O}_{3} / \text { encapsulation }\end{array}$ & Soybean oil & 2 & $15: 1$ & 70 & 3 & 98.8 & 4 & [113] \\
\hline $\mathrm{KF} / \mathrm{CaO}-\mathrm{Fe}_{3} \mathrm{O}_{4}$ & $\begin{array}{l}\text { facile impregnation } \\
\mathrm{m}\end{array}$ & Stillingia oil & 4 & $12: 1$ & 65 & 3 & 95 & 14 & [114] \\
\hline $\begin{array}{c}\mathrm{Fe}_{3} \mathrm{O}_{4} @ \mathrm{SiO}_{2-} \\
\mathrm{SO}_{3} \mathrm{H}\end{array}$ & $\begin{array}{c}\text { Step-wise } \\
\text { co-precipitation }\end{array}$ & $\begin{array}{c}\text { Crude } \\
\text { Jatropha oil }\end{array}$ & 8 & $9: 1$ & 80 & 3.5 & 98 & 10 & [115] \\
\hline $\mathrm{IL}-\mathrm{Fe}_{3} \mathrm{O}_{4} @ \mathrm{SiO}_{2}$ & $\begin{array}{l}\text { Solvothermal } \\
\text { method/Stöber } \\
\text { method }\end{array}$ & Oleic acid & 10.8 & $6: 1$ & 110 & 4 & 92.9 & 8 & [116] \\
\hline $\begin{array}{l}\text { Polymeric acidic } \\
\mathrm{ILs} / \mathrm{Fe}_{3} \mathrm{O}_{4} @ \mathrm{SiO}_{2}\end{array}$ & $\begin{array}{l}\text { Solgel/acile } \\
\text { chemical } \\
\text { co-precipitation }\end{array}$ & $\begin{array}{l}\text { Soybean wth } \\
\text { high FFAs }\end{array}$ & 8 & $30: 1$ & 130 & 8 & 94.2 & 5 & [117] \\
\hline
\end{tabular}

The catalytic activity and reusability of the solid acid catalyst can be increased substantially by loading it onto a magnetized support. Silica was coated on a magnetite $\mathrm{Fe}_{3} \mathrm{O}_{4}$ nanoparticle and factionalized by sulfonic acid using the step-wise co-precipitation method. The obtained $\mathrm{Fe}_{3} \mathrm{O}_{4} @ \mathrm{SiO}_{2}-\mathrm{SO}_{3} \mathrm{H}$ nanoparticle catalyst was used for simultaneous esterification of free FFAs and transesterification of triglycerides in crude Jatropha oil that has a high initial acid value (AV) of $13.2 \mathrm{mg} \mathrm{KOH} \mathrm{g}^{-1}$. The catalyst showed $98 \pm 1 \%$ conversion using the optimized reaction conditions of methanol:oil molar ratio of 9:1, $8 \mathrm{wt} \%$ catalyst loading, $80{ }^{\circ} \mathrm{C}$, and $3.5 \mathrm{~h}$. Magnetization of the catalyst facilitated the recovery and the reusability of the catalyst up to 10 cycles [115].

Ionic liquid (IL), which is emerging as a green catalyst for biodiesel production, can be significantly enhanced by loading it on magnetic nanoparticles [72]. A nano-magnetic particle $\mathrm{Fe}_{3} \mathrm{O}_{4}$ was prepared and coated by silica by $\mathrm{Wu}$ et al. [116]. The developed product, $\mathrm{Fe}_{3} \mathrm{O}_{4} @ \mathrm{SiO}_{2}$, was further functionalized using the dual Brønsted acidic ionic liquid $\left[\mathrm{SO}_{3} \mathrm{H}-\left(\mathrm{CH}_{2}\right)_{3}-\mathrm{HIM}\right]\left[\mathrm{HSO}_{4}\right]$. 3-chloropropyltrimethoxysilane was used as a linker. The performance of IL-Fe $\mathrm{O}_{4} @ \mathrm{SiO}_{2}$ in the ethanolysis of oleic acid was investigated. High conversion $(92.9 \%)$ of oleic acid to biodiesel was reached under suitable reaction conditions reaction time $(4 \mathrm{~h})$, reaction temperature $\left(110{ }^{\circ} \mathrm{C}\right)$, catalyst dosage $(10.8 \mathrm{wt} \%)$, and the molar ratio of ethanol to oleic acid (6:1). The catalyst was easily recovered and reused several times and retained its activity for eight cycles [116]. In a recent study, Xie et al. [117] developed a novel catalyst by functionalizing $\mathrm{Fe}_{3} \mathrm{O}_{4} @ \mathrm{SiO}_{2}$ magnetic nanoparticle using Polymeric IL to impart the composite support strong-acidic surface. They used, for this purpose, 1-vinyl-3-(3-sulfopropyl) imidazolium hydrogen sulfate as a monomer and 1.4-butanediyl3,3'-bis-1-vinylimidazoliu hydrogen sulfate as a cross-linker agent. They studied the efficiency of this solid acidic catalyst for simultaneous esterification and transesterification reactions of low-quality feedstock. This study proved that the combination of polymeric ILs and a magnetic porous support is very effective for utilization of low feedstock with 
high free fatty acid for biodiesel production in one step as the developed polymeric acidic $\mathrm{ILs} / \mathrm{Fe}_{3} \mathrm{O}_{4} @ \mathrm{SiO}_{2}$ showed high tolerance to both FFAs and water. A $94.2 \%$ conversion of simulated low-quality soybean was achieved at optimized conditions (methanol/oil molar ratio, 30:1; reaction time, $8 \mathrm{~h}$; reaction temperature, $130^{\circ} \mathrm{C}$; catalyst dosage, $8 \mathrm{wt} \%$ ). Moreover, the solid catalyst was simply reused five times without much loss of its catalytic activity.

\subsection{Natural/Waste Based Heterogeneous Catalysis}

Although various heterogeneous catalysts have been reported in the literature for biodiesel production, most of them are expensive or complicated to prepare. Thus, their industrial application is limited. Waste from industrial operations and the environment can help create a low-cost solid base catalyst that can encourage a sustainable and environmentally friendly approach to biodiesel synthesis $[118,119]$. In this field, many researchers are trying to develop low-cost and more natural heterogeneous catalysts. The utilization of industrial wastes for catalyst synthesis is considered adequate disposal and simultaneously reduces the costs of catalyst production [120]. Waste material with a wide source, low price, favorable biodegradability, and is environmentally friendly is suitable for preparing the catalyst [121].

\subsubsection{Solid Basic Catalysis}

Many researchers have proved industrial waste shells to be a cheap natural source of $\mathrm{CaO}$ for application as a solid base catalyst with high effective cost instead of highcost analytical reagent-grade chemicals [122]. Table 5 shows the optimized condition for biodiesel production by solid-base catalysts derived from industrial waste shells. The derived catalysts were prepared by calcination at temperatures in the range of 700 to $1000{ }^{\circ} \mathrm{C}$ for a period range from 2 to $4 \mathrm{~h}$. A combination of fly ash and the waste eggshell is considered as a novel route to produce low-cost supported-base catalysts with superior catalytic activity and reusability [122]. Waste shells with a low content of $\mathrm{CaO}$ activity could be increased by loading them on an active base. The KI impregnated shrimp shell-derived catalyst [121] was prepared by a novel tri-step synthetic strategy first, carbonization at $450{ }^{\circ} \mathrm{C}$, loading $\mathrm{KI}$ of $25 \mathrm{wt} \%$, and activation at $250{ }^{\circ} \mathrm{C}$. The resultant active sites on the surface of the derived catalyst came from incompletely carbonized shrimp shells with KI during the activation process.

Table 5. Biodiesel production by solid base catalysts derived from industrial wastes.

\begin{tabular}{|c|c|c|c|c|c|c|c|c|c|}
\hline Feedstock & Derived Catalyst & Active Phase & $\begin{array}{c}\text { Loading } \\
\text { Catalyst } \\
\text { wt } \% \text { of Oil }\end{array}$ & $\begin{array}{l}\text { Methanol to } \\
\text { Oil Molar } \\
\text { Ratio }\end{array}$ & $\begin{array}{c}\text { Temperature } \\
{ }^{\circ} \mathrm{C}\end{array}$ & $\begin{array}{l}\text { Reaction } \\
\text { Time h }\end{array}$ & $\begin{array}{l}\text { Biodiesel } \\
\text { Yield wt } \%\end{array}$ & $\begin{array}{c}\text { Catalyst } \\
\text { Reusability }\end{array}$ & Ref. \\
\hline Soybean oil & $\begin{array}{l}\text { Clcined waste } \\
\text { eggshell }\end{array}$ & $\mathrm{CaO}$ & 3 & $9: 1$ & 65 & 3 & 95 & 17 & [123] \\
\hline Soybean oil & $\begin{array}{c}\text { Calcined waste } \\
\text { Rohu fish (Labeo } \\
\text { rohita) }\end{array}$ & $\begin{array}{l}\beta \text {-tri-calcium } \\
\text { phosphate }\end{array}$ & 1.01 & $6.27: 1$ & 70 & 5 & 97.73 & 6 & [124] \\
\hline Rapeseed oil & $\begin{array}{l}\text { KI impregnated } \\
\text { shrimp shell }\end{array}$ & $\mathrm{Ca}_{3}\left(\mathrm{PO}_{4}\right)_{2}, \mathrm{KI}$ & 2.5 & $9: 1$ & 65 & 3 & 89.1 & 3 & [121] \\
\hline Soybean oil & $\begin{array}{l}\text { Fly ash supported } \\
\mathrm{CaO} \text { (waste } \\
\text { eggshell-derived) }\end{array}$ & $\mathrm{CaO}$ & 1.0 & $6.9: 1$ & 70 & 5 & 96.97 & 18 & [122] \\
\hline Palm oil & $\begin{array}{l}\text { Calcined waste } \\
\text { animal bones }\end{array}$ & hydroxyapatite & 20 & $18: 1$ & 65 & 4 & 96.78 & 5 & [125] \\
\hline Soybean & $\begin{array}{l}\text { Calcined waste } \\
\text { mussel shell }\end{array}$ & $\mathrm{CaO}$ & 5 & $12: 1$ & 70 & 1.5 & $>90$ & 7 & [126] \\
\hline $\begin{array}{l}\text { Waste frying } \\
\text { soybean oil }\end{array}$ & Calcined snail shell & $\mathrm{CaO}$ & $3.0-3.5$ & $8.45: 1$ & 60 & 7 & 87.28 & - & [127] \\
\hline
\end{tabular}


Table 5. Cont.

\begin{tabular}{|c|c|c|c|c|c|c|c|c|c|}
\hline Feedstock & Derived Catalyst & Active Phase & $\begin{array}{c}\text { Loading } \\
\text { Catalyst } \\
\mathbf{w t} \% \text { of Oil } \\
\end{array}$ & $\begin{array}{l}\text { Methanol to } \\
\text { Oil Molar } \\
\text { Ratio }\end{array}$ & $\begin{array}{c}\text { Temperature } \\
{ }^{\circ} \mathrm{C}\end{array}$ & $\begin{array}{l}\text { Reaction } \\
\text { Time h }\end{array}$ & $\begin{array}{l}\text { Biodiesel } \\
\text { Yield wt } \%\end{array}$ & $\begin{array}{c}\text { Catalyst } \\
\text { Reusability }\end{array}$ & Ref. \\
\hline Palm oil & $\begin{array}{l}\text { Calcined waste } \\
\text { capiz (Amusium } \\
\text { cristatum) shell }\end{array}$ & $\mathrm{CaO}$ & 3 & $8: 1$ & 60 & 6 & 93 & 3 & [128] \\
\hline Soybean oil & Waste scale & $\begin{array}{c}\mathrm{CaO}-\mathrm{MgO}-\mathrm{Fe}_{2} \mathrm{O}_{3}- \\
\mathrm{Al}_{2} \mathrm{O}_{3}-\mathrm{SiO}_{2}\end{array}$ & 1 & $12: 1$ & 70 & 5 & 93 & - & [129] \\
\hline $\begin{array}{l}\text { Waste } \\
\text { cooking oil }\end{array}$ & $\begin{array}{l}\text { Waste chicken } \\
\text { eggshells }\end{array}$ & $\begin{array}{c}\text { Eggshell-CaOC-H-D } \\
\text { (calcination- } \\
\text { hydration- } \\
\text { dehydration) } \\
\text { Eggshell-CaDG } \\
\text { (calcium } \\
\text { diglyceroxide) }\end{array}$ & $1.5-3$ & $10: 1-12: 1$ & $60-65$ & $50-90 \mathrm{~min}$ & $93.10-96.07$ & - & [130] \\
\hline Soybean oil & $\begin{array}{l}\text { Calcined oyster } \\
\text { shell }\end{array}$ & $\mathrm{CaO}$ & 25 & $6: 1$ & 60 & 5 & 73.8 & - & [131] \\
\hline Jatropha oil & $\begin{array}{c}\text { Musa paradisiaca } \\
\text { trunk }\end{array}$ & $\begin{array}{l}\text { Carbonates and } \\
\text { oxides of alkali and } \\
\text { alkaline earth } \\
\text { metals }\end{array}$ & 5 & $9: 1$ & 65 & $9 \mathrm{~min}$ & 97.65 & 3 & [132] \\
\hline $\begin{array}{l}\text { Leather } \\
\text { tanning } \\
\text { waste }\end{array}$ & Crab shell & $\mathrm{CaO}$ & 3.87 & $\begin{array}{c}12: 1 \\
\text { (ethanol:oil) }\end{array}$ & 60 & 3.58 & 98.7 & 4 & [133] \\
\hline
\end{tabular}

\subsubsection{Solid Acidic Catalysis}

Inorganic-oxide acids catalysts, such as zeolite, Niobic acid, silica-supported zirconium sulfate, along with acidic acid exchange resins, such as Amberlyst-15 and Nafion-NR50, suffer from some common problems: low acid site concentration, micro-porosity and hydrophilic character of catalysts surface sites, leaching, and high cost. These problems can be avoided by sulfonating incompletely carbonized natural organic materials, such as sugar, starch, cellulose, and biomass wastes. Incomplete carbonization converts these materials to irregular aromatic carbon structures with large pores that trap the acidic groups $\left(-\mathrm{SO}_{3} \mathrm{H}\right)$ by sulfonation. The resultant solid acid catalyst is highly stable due to the electron drawing effect caused by the aromatic groups. In addition, this derived catalyst is tolerant to the presence of water in the feeds stock due to its hydrophobic characteristics [123-125]. Thus, this method is considered to be a novel method to prepare high-performance carbon-based solid acid catalysts cheaply from naturally occurring molecules. Many researchers proved that carbon-based solid acid catalysts derived from industrial waste biomass are economical, eco-friendly, and promising sustainable catalysts to produce biodiesel from low-cost feeds stock with high FFAs or water. Deeba et al. [134] studied the transesterification of non-edible waste cooking oil using yeast residue-based solid acid (YSA) catalyst. YSA was produced from waste yeast residue via sulfonation. They showed that at $4 \mathrm{wt} \%$ catalyst concentration and 10:1 methanol to oil molar ratio, the fatty acid methyl ester (FAME) yield of waste cooking oil was $96.2 \mathrm{wt} \%$ at $60^{\circ} \mathrm{C}$ and $94.8 \mathrm{wt} \%$ for yeast oil at $70{ }^{\circ} \mathrm{C}$. Bagasse (waste biomass from a sugar refinery) was found by Lou et al. [127] to be a novel carbon-based solid acid catalyst. The optimized catalyst was produced under optimum carbonization at $648 \mathrm{~K}$ for $0.5 \mathrm{~h}$ and sulfonation at $423 \mathrm{~K}$. The produced catalyst efficiently converted waste cooking oil with $38.6 \mathrm{wt} \%$ FFAs into biodiesel and afforded a high yield of about $93.8 \%$ within $12 \mathrm{~h}$. The derived catalyst could be reusable for at least eight cycles without much deterioration in its catalytic activity. Glycerol, a by-product from biodiesel refineries, was used by Song et al. [135] to prepare carbon-based solid catalysts through in situ partial carbonization and sulfonation at $180{ }^{\circ} \mathrm{C}$ for $0.5 \mathrm{~h}$. The derived catalyst showed high catalytic activity and recycling performance in the esterification of oleic acid and transesterification of triolein compared to commonly used Ambrlyest-15. Therefore, according to this study, it is suggested that carbon-based solid acid catalyst is a sustainable route for the utilization of glycerol and the production of biodiesel. Shu et al. [124] had prepared a carbon-based solid acid catalyst by sulfonation of incompletely carbonized vegetable oil asphalt (a solid residue from biodiesel refinery) 
and used it to catalyze the transesterification of cotton seed oil. Depending on the TGA analysis, the catalyst showed high thermal stability at $270{ }^{\circ} \mathrm{C}$. Therefore, it was possible to obtain high biodiesel yield from the cotton seed oil (89.93\%) at a shorter reaction time $(3 \mathrm{~h})$ and low methanol to oil mass ratio (18:1) when the reaction was processed at $260{ }^{\circ} \mathrm{C}$. Such results, practically, could not be achieved with conventional homogenous sulfuric acid. Pau et al. [126] had successfully prepared carbon-based solid acid from kraft lignin (waste biomass from paper mills) via chemical activation by phosphoric acid, pyrolysis, and sulfuric acid. The resultant novel catalyst was used for biodiesel production from nonpretreated Jatropha oil with a high acid value $(12.7 \mathrm{mg} \mathrm{KOH} / \mathrm{g})$ in a single-step process, $96.3 \%$ biodiesel yield was obtained. The catalyst could be used three times with little deactivation under optimized conditions.

Farabi et al. [136] presented a novel approach to cut down the cost of biodiesel production based on utilizing biomass wastes for both catalyst synthesis and biodiesel production. They used a palm kernel shell to prepare a carbon-based catalyst. The active sites of $\mathrm{SO}_{3} \mathrm{H}$ were trapped on the surface of the carbonaceous catalyst by using chlorosulfonic acid $\left(\mathrm{ClSO}_{3} \mathrm{H}\right)$ at $70{ }^{\circ} \mathrm{C}$ for 4 . The produced sulfonated palm kernel shell catalyst $\left(\mathrm{PKS}^{-} \mathrm{SO}_{3} \mathrm{H}\right)$ exhibited high catalytic activity to convert palm fatty acid distillate (a by-product in palm oil refining) to biodiesel. High biodiesel yield (95\%) and FFAs conversion (97\%) were achieved under optimized parameters, catalyst loading of $4 \mathrm{wt} \%$, methanol-to-palm fatty acid distillate molar ratio of $15: 1$, reaction temperature of $65^{\circ} \mathrm{C}$, and the reaction time was $1 \mathrm{~h}$. The prepared catalyst maintained its catalytic activity for up to four consecutive cycles. To facilitate the separation of PKS $\left(\mathrm{PKS}_{-} \mathrm{SO}_{3} \mathrm{H}\right)$ catalyst from the reaction media, Quah et al. [137] used a magnetized form of PKS-SO3H by sulfonating a composite of biochar derived from $\mathrm{PKS}$ and ferrite $\mathrm{Fe}_{3} \mathrm{O}_{4}$. The maximum biodiesel yield of $90.2 \%$ was obtained under these optimized temperature values at $65.07^{\circ} \mathrm{C}, 102 \mathrm{~min}, 3.66 \mathrm{wt} \%$ of the catalyst loading, and the methanol/oil ratio of 13:1. The catalyst performance was acceptable during the first four cycles. The authors proposed coating the catalyst with an extra layer to reduce the leaching of Fe. Table 6 summarizes the studies on carbon-based solid acid catalysts for biodiesel production.

Table 6. Carbon-based solid acid catalysts for biodiesel production.

\begin{tabular}{|c|c|c|c|c|c|c|c|c|}
\hline \multirow{2}{*}{$\begin{array}{l}\text { Carbonaceous } \\
\text { Substrate }\end{array}$} & \multirow[b]{2}{*}{ Feedstock } & \multicolumn{4}{|c|}{ Reaction Parameter } & \multirow{2}{*}{$\begin{array}{c}\text { Biodiesel Yield } \\
\text { wt } \%\end{array}$} & \multirow[b]{2}{*}{ Reusability } & \multirow[b]{2}{*}{ Ref. } \\
\hline & & $\begin{array}{c}\text { Catalyst } \\
\text { Loading } \mathbf{w t} \%\end{array}$ & $\begin{array}{l}\text { Methanol to Oil } \\
\text { Molar Ratio }\end{array}$ & $\begin{array}{c}\text { Temperature } \\
{ }^{\circ} \mathrm{C}\end{array}$ & $\underset{\mathrm{h}}{\operatorname{Time}}$ & & & \\
\hline Yeast residue & Waste cooking oil & 4 & $10: 1$ & 60 & 8 & 96.2 & 4 & [134] \\
\hline Bagasse & $\begin{array}{l}\text { Waste cooking oil } \\
38.6 \mathrm{wt} \% \text { FFAs }\end{array}$ & 4 & - & - & 12 & 93.8 & 8 & [127] \\
\hline Glycerol & Oleic acid/triolein & 10 & $60: 1$ & 80 & 10 & 99 & 5 & [135] \\
\hline Asphalt & cotton seed oil & 0.2 & $18: 1$ & 260 & 3 & 89.93 & 3 & [124] \\
\hline Kraft lignin & Jatropha oil & 5 & $12: 1$ & 80 & 5 & 96.3 & 3 & [126] \\
\hline Palm kernel shell & $\begin{array}{l}\text { palm fatty acid } \\
\text { distillate }\end{array}$ & 4 & $15: 1$ & 65 & 1 & 95 & 4 & [136] \\
\hline $\begin{array}{l}\text { Magnetized sulfonated } \\
\text { Palm kernel shell }\end{array}$ & Waste cooking oil & 3.66 & $13: 1$ & 65 & 1.42 & 90.2 & 4 & [137] \\
\hline
\end{tabular}

\section{Enzymatic Catalysis}

The chemical catalysis process for producing biodiesel consumes energy and creates undesirable by-products, such as soaps and polymeric pigments, which impede product separation from glycerol and di- and monoacylglycerols, which can be eliminated using enzymatic catalysis [138]. Biodiesel production by enzymatic catalysis has emerged as the most promising new technology [139-141]. This is evidenced by the intensive publications on enzymatic transesterification of lipids (oils/fats) in the last two decades [142-146]. Lipases, which are glycerol ester hydrolases (EC 3.1. 1. 3.) [131], catalyze the hydrolysis of different esters. However, their synthetic activity is enhanced in low water mediums by catalyzing the reversible esterification and transesterification reactions. Microorganisms 
present as a versatile source of lipases in nature [147]. Lipases can simultaneously catalyze the esterification and transesterification of FFAs and triglycerides present in the lowquality feedstock with no or less downstream operation, fewer processes, lower alcohol to oil ratio, easy separation of products with high purity at mild reaction conditions (low temperature and pressure). Hence, besides low energy consumption, enzymatic catalysis has numerous advantages over conventional chemical catalysis [148-151]. Moreover, the formation of undesired products is eliminated due to lipase's high specificity and selectivity towards the ester bond. The additional advantages of lipases are owed to their high thermo-stability at a wide range of $\mathrm{pHs}$, easy handling, and the possibility of reusing and operating them on a continuous bed reactor when they are immobilized on suitable solid support [152,153]. The efficiency of lipase as a biocatalyst can be improved by protein engineering [154]. From an environmental point of view, lipases are considered to have major importance in natural ecosystems since they are involved in carbon storage in soil or litter. Therefore, enzymatic transesterification offers an environmentally more attractive option to conventional processes [149,155].

Although enzymatic catalysis seems to be an excellent alternative to conventional homogeneous-alkali catalysis, it is not industrially implemented. Only a small pilot plant of 20,000 tons/year is being tested in China [149]. The high cost of an enzyme, due to the complicated purification, recovery, and immobilization steps required, is the main barrier to its industrial application. In addition, the low rate of reaction, due to the deactivation of lipase, caused by the short-chain alcohol (co-substrate) and glycerol (byproduct), these systems, economically, are not attractive for industrial-scale production of biodiesel [156,157].

In the enzymatic catalyzed-transesterification presence of FFAs and water in the feedstock effect the conversion of triglycerides to biodiesel products positively. Water assists in maintaining enzyme activity. While FFAs reduce the inhibition of lipase $[158,159]$. However, the excess of water resulting from the esterification reaction would reduce the biodiesel yield due to the hydrolysis reaction. Therefore, the effect of water should be maintained experimentally to aid biodiesel production at a large scale $[160,161]$. Moreover, the lipase activity is inhibited by the presence of phospholipids in the feedstock. Hence, the type of impurities of the feedstock is of great importance in lipase-catalyzedtransesterification [162].

\subsection{Screening of Lipases}

Lipases are classified into two broad categories: extracellular lipases and intercellular lipases. Extracellular lipases are extracted from the live-producing microorganism broth and then purified. The major microorganism producers for extracellular lipases are Mucor miehei, Rhizopus oryzae, Candidaantarctica, and Pseudomonas cepacia. Intercellular lipase remains either inside the cell or in the cell-producing wall. In both cases, extracellular lipases and intercellular lipases are immobilized because pure lipase has shallow catalytic activity. However, free lipases are used to investigate their sensitivity towards the alcoholysis reaction [138]. Soumanou and Bornscheuer [163], in their study on the effects of different variables on the enzymatic alcoholysis reaction of sunflower oil, had screened six different crude microbial lipases (Table 7). They used triolein for methanolysis in n-hexane as an organic solvent. From the initial rate of alcoholysis reaction, only three enzymes showed considerable catalytic activity. P. fluorescen lipase was chosen for further investigation depending on the highest conversion after $24 \mathrm{~h}$. 
Table 7. Screening commercial crude lipases for alcoholysis of pure triolein with methanol in n-hexane (3:1 triolein to methanol ratio in $2 \mathrm{~mL}$-hexane, $10 \%$ lipase ( $w / w$ triolein), and $40{ }^{\circ} \mathrm{C}$ ).

\begin{tabular}{|c|c|c|c|c|}
\hline \multirow{2}{*}{ Lipase } & \multirow{2}{*}{$\begin{array}{l}\text { Commercial } \\
\text { Code }\end{array}$} & \multirow{2}{*}{$\begin{array}{c}\text { Initial Rate } \\
(\mu \mathrm{mol} / \mathrm{mg} / \mathrm{min})\end{array}$} & \multicolumn{2}{|c|}{ Conversion (\%) } \\
\hline & & & $5 \mathrm{~h}$ & $24 \mathrm{~h}$ \\
\hline A. niger & A 6 & 0 & $<0.01$ & $<0.1$ \\
\hline C. rugosa & AY 30 & 0 & $<0.4$ & $<1.1$ \\
\hline P. cepacia & PS & 0.4 & 4.5 & 23.2 \\
\hline P. fluorescens & AK & 1.3 & 17.0 & 48.0 \\
\hline P. camembertii & G 50 & 0.2 & 0.3 & 4.9 \\
\hline R. oryzae & F-AP 15 & 0 & 0.2 & 0.8 \\
\hline
\end{tabular}

\subsection{Treatments of Lipase Deactivation}

The effect of methanol on lipase activity was investigated thoroughly by Shimada et al. [164]. They found that, by using immobilized C.antarctica, methanolysis of vegetable oil decreased significantly with the addition of methanol $>1 / 2$ molar equivalent of methanol for the stoichiometric amount. To overcome the poisonous effect of methanol, they tried adding methanol step-wise in three successive additions of $1 / 3$ molar equivalents of methanol. They achieved $98.4 \%$ oil conversion to its corresponding methyl esters after a total reaction time of $48 \mathrm{~h}$. The catalyst was able to be reused with ester conversion of more than $95 \%$, even after 50 cycles (100 days). Thus, step-wise addition of methanol could reduce the cost, especially if it is employed in a continuous fixed bed reactor. Chen and $\mathrm{Wu}$ [165] studied the deactivation of the enzyme by linear and branched alcohols. They used immobilized C. antarctica for the transesterification of soybean oil. They revealed that the enzyme was inhibited by linear alcohols more than the branched alcohols, which were more soluble in the triglyceride. Moreover, the degree of deactivation was inversely proportional to the length of the carbon chain of the linear alcohol. It was concluded that the deactivation of the enzyme was caused by the immiscibility of the short alcohol (methanol or ethanol) in the triglycerides, besides the adsorption of the alcohol droplet on the immobilized enzyme. Isopropanol, soybean oil, 2-propanol, and tert-butanol were used for washing the deactivated enzyme. The completely deactivated immobilized C. antractia had restored $56 \%$ and $75 \%$ of its original activity when washed with 2 - butanol and tertbutanol, respectively. Meanwhile, immersion pretreatment by these alcohols could increase the activity of the enzyme tenfold compared to an un-pretreated enzyme. Such alcohols have the ability to dissolve the adsorbed methanol droplets around the enzyme. Therefore, Chen and Wu proposed the regeneration of lipase by washing it with C 3 or C4 alcohol. This method was considered to be more practical compared to the step-wise addition of methanol, which needs high precision to maintain methanol at a low concentration, also the low rate of the reaction. Lu et al. [166] found a dissimilar result when Candida sp99-125 immobilized on a textile membrane was treated by short-chain alcohol from n-propyl alcohol to isobutyl alcohol. It seems that the pretreatment method depends on the origins of the lipase and the type of its immobilizing material.

The liberated glycerol, in a free solvent medium, inhibits the biocatalyst by blocking its entry pores [167]. The inhibitory effect of glycerol is significant, particularly in continuous operation $[168,169]$. In a systemic study, Xu et al. [170] investigated glycerol's inhibitory mechanism in ethanolysis of rapeseed oil. They concluded that the type of immobilizing support is the factor that influences the adsorption of the glycerol on the surface of the enzyme carrier. Supports for lipase immobilizing should not adsorb glycerol. They proved that supports, such as silica and polystyrene, which have a great affinity to glycerol, are not appropriate for immobilizing lipase. While supports with no affinity to adsorb glycerol, such as polymethyl methacrylate or polypropylene, are more convenient. Silica gel was found, among other solid materials, to be the most effective adsorbent to remove glycerol from the reaction media. Over $90 \%$ biodiesel yield was achieved in transesterification 
reaction catalyzed by immobilized Mucor Meiheiin in the presence of 1.25 silica weight equivalents to glycerol produced, regardless of the type of the oil or alcohol [171]. Adsorptive purification in a continuous process using ion exchange resin was satisfactory to maintain the content glycerol at a low concentration for more than 140-bed volumes and repeated after regeneration of the resin by using methanol [168].

Lately, there has been a trend to carry out enzymatic alcoholysis of triglycerides in an organic solvent. The reaction medium (oil, methanol, and glycerol) is partially soluble in hydrophilic solvents (e.g., acetone, acetonitrile) or in hydrophobic solvents (hexane, isooctane, and heptane). However, tert-butanol, a moderately hydrophilic solvent, can dissolve oil, methanol, and glycerol. Therefore, tert-butanol was considered a novel organic solvent to simultaneously eliminate the inhibitory effect of glycerol and methanol. In addition, lipases do not act on tertiary alcohol [172,173]. Among different organic solvents (hydrophilic, hydrophobic), tert-butanol was found to be the most suitable solvent in the methanolysis of cooking-waste palm oil. An $88 \%$ FAME yield was achieved under optimal conditions (methanol/oil molar ratio 4:1, $4 \%$ Novozyme 435 based on oil weight, $40{ }^{\circ} \mathrm{C}$ reaction temperature, $200 \mathrm{rpm}$, and $12 \mathrm{~h}$ reaction time) [172]. Li et al. [174] reported that a combined mixture of Lipozyme TL IM and Novozyme 435 maintained its catalytic activity, even after 200 cycles, in the methanolysis of rapeseed oil in the presence of tert-butanol as a reaction medium. A 95\% biodiesel yield was achieved under the optimum conditions (tert-butanol/oil volume ratio 1:1, methanol/oil molar ratio 4:1,3\% Lipozyme TL IM, 1\% Novozyme 435 based on the oil weight, $35{ }^{\circ} \mathrm{C}$ reaction temperature, $130 \mathrm{rpm}$, and $12 \mathrm{~h}$ reaction time).

However, flammable and volatile organic solvents diminish the green characteristics of bio-catalysis. ILs are emerging as a novel replacement for volatile organic solvents. ILs are organic salts remaining as a liquid at an ambient temperature. They are green solvents due to their undetectable vapor pressure. Their use can enhance the activity, selectivity, and stability of the enzyme. Moreover, it is possible to recycle both the biocatalyst and IL [163,175-177]. Many works demonstrate that ILs are superior solvents for lipase transesterification of triglycerides [178-180]. The high cost of ILs is the main barrier to their use in biodiesel production commercially [175]. Exploring friendly, inexpensive solvents for lipase-catalyzed biodiesel production is in progress. Solvent systems, such as a combination of supercritical fluids and ILs [181,182], choline-based eutectic solvents [183,184], and diether glycol (Glymes) [175], are being tried.

The negative effect of both methanol and glycerol could be avoided in free solvent systems by developing alternative acyl acceptors. In this field, methyl acetate presents as a novel acyl acceptor in lipase-catalyzed biodiesel production. Du et al. [185] investigated transesterification of soybean oil in the presence of Novozyme 435 by using different acyl acceptors. Repeatedly significant (100 cycles) lipase was found with methyl acetate. High biodiesel yields, $92 \%$, could be obtained, from refined oil, under optimum conditions (methyl acetate/oil molar ratio 12:1, 30\% Novozyme 435 based on oil weight, $40{ }^{\circ} \mathrm{C}$, $150 \mathrm{rpm}$, and $14 \mathrm{~h}$ ). The high enzyme consumption was attributed to the low reaction rate of methyl acetate. However, the high reusability of the lipase could minimize the impact of this negative effect. In addition, the dilution effect caused by the high methyl acetate/oil molar ratio could reduce the inhibitory effect of lipids, as indicated by an equal biodiesel yield produced from crude and refined soybean oils. Moreover, the production cost could be reduced by using acetyl acyl glycerol, a by-product, which has a higher value than glycerol. Ognjanovic et al. [186] demonstrated that methyl acetate is a promising acyl acceptor to improve the stability of the immobilized lipase on an industrial production scale. Eight consecutive, $8-10$ h uses, with residual activity $93.6 \pm 3.75 \%$ was achieved in a packed reactor [186].

Talukder et al. [187] tried to minimize the methanol deactivation of lipase by developing a two-step process, free of glycerol, to convert crude palm oil (CPO) to biodiesel. In the first step, $\mathrm{CPO}$ was hydrolyzed entirely to fatty acids by Candida rugosa under optimal conditions (buffer to CPO 1:1 (v/v), buffer $\mathrm{pH} 7.0$, lipase $0.1 \mathrm{wt} \%$ to $\mathrm{CPO}$, isooctane to 
CPO $1: 1(v / v)$, temperature $30^{\circ} \mathrm{C}$, reaction time $4 \mathrm{~h}$, and shaking speed $\left.250 \mathrm{rpm}\right)$. The second step was the esterification of the resultant fatty acids catalyzed by Novozyme 435 lipase in an excess amount of methanol. The high biodiesel yield of $98 \%$ was obtained when the reactions conditions were maintained at methanol/fatty acids molar ratio 1.2:1, $0.04 \mathrm{~g}$ Novozyme 435 , temperature $40^{\circ} \mathrm{C}$, reaction time $2 \mathrm{~h}$, and shaking speed $250 \mathrm{rpm}$. C. rugosa and Novozyme 435 lipases showed considerable repeated usage, 10 and 50 cycles, respectively. The significance of the developed two-step process is its ability to produce biodiesel from low feedstock with high FFAs or water, compared to single-step Novozyme 435 catalyzed methanolysis in t-butanol or step-wise addition of methanol in free solvent systems. Meng et al. [188] aimed to make the enzymatic two-step production of biodiesel more cost-effective and independent from petroleum sources. They used a comparatively cheap kind of lipase (Yarrowia lipolytica) and ethanol as the substrate to convert soybean oil to biodiesel. The hydrolysis of the acid oil was firstly carried out by the Yarrowia lipolytica crude brothe lipase. In the second step, the fatty acids are esterified by ethanol in the presence of the immobilized Yarrowia lipolytica on fabric membrane. The degree of esterification was maintained over $82 \%$ with 25 reuses, each with a 3 h reaction time.

\subsection{Immobilization of Lipases}

The cost of the lipase enzyme is the main obstacle for the commercial production of biodiesel by enzymatic alcoholysis of triglycerides. The cost-effectiveness of immobilized lipases depends on support materials and immobilization methods. Support materials should be low cost and provide an adequate large surface and the least diffusion limitation in the transport of substance and product for the enzymatic reaction [189]. There are several methods for lipase immobilization, including physical adsorption onto a macro porous support [189-192], covalent bonding to a solid support [189,193-195], physical entrapment with a polymer matrix support [196-199], encapsulation [200,201], and crosslinking [160,202-204].

Lipase-catalyzed biodiesel production could be more cost-effective and environmentally friendly by using natural biopolymer as a matrix in the immobilization of lipase [200]. A novel method was developed by Shu et al. [205] to immobilize Candida rugosa lipase onto cotton cloth with the aid of polyethyleneimine and glutaraldehyde cross-linking processes. The enzymatic performance of the obtained immobilized lipase was examined in the ethanolysis of butyric acid. A conversion yield of $91.2 \%$ to ethyl butyrate was obtained at $25{ }^{\circ} \mathrm{C}$. The immobilized lipase retained half of its initial activity after 12 repeated cycles, with a half-life of about $300 \mathrm{~h}$. Microbial lipase from Thermmyces launginosus was immobilized on olive pomace, the industrial by-product of olive oil production, by Yücel [206]. The obtained immobilized lipase was influential in the production of biodiesel from olive oil by a three-step addition of methanol. A maximum biodiesel yield of $93 \%$ was achieved, under optimized conditions, at $25{ }^{\circ} \mathrm{C}$ in a $24 \mathrm{~h}$ reaction. The immobilized lipase retained its activity during ten repeated batch reactions. Plant fiber from Cyperus papyrus L. was used by Chauchinda et al. [207] to immobilize Candida rugosa for biodiesel synthesis from palm oil. Immobilization of the lipase by physical adsorption in heptanes gave satisfactory results in both transesterification and hydrolysis-esterification routes for methanolysis and ethanolysis of palm oil.

Compared to a free and immobilized enzyme, microbial whole-cells containing intracellular lipases immobilized onto biomass support particles (BSPs) are more effective in improving cost-efficiency. Immobilization can be achieved spontaneously during batch cultivation, and no purification of lipase is necessary [208]. A comparative study of immobilized-whole cell and commercial lipases was carried out by Tamalampui et al. [209] in the alcoholysis of Jatropha oil. They reported that Rhizopus oryzea immobilized onto BSPs made of reticulated polyurethane foams could catalyze the methanolysis of Jatropha oil more effectively than Novozyme 435. The maximum methyl ester content in the reaction mixture was $80 \mathrm{wt} \%$ and $76 \mathrm{wt} \%$ after $60 \mathrm{~h}$ and $90 \mathrm{~h}$, respectively. 


\section{Transesterification by Ultrasonic and Microwave Irradiation}

\subsection{Ultrasonic Irradiation Assisted Catalysis}

Molecules acquire unique physical and chemical properties when exposed to ultrasonic radiation. Ultrasonic cavitation has emerged as a new technique for mass transfer in chemical processes. The production of biodiesel by the ultrasonic irradiation method is found to have the advantages of reducing processing time, amount of catalyst and alcohol required, separation time, and reaction temperature [210-213]. Investigations on the effect of ultrasound radiation on the transesterification of triglycerides to develop sonochemical reactors for biodiesel production are in progress. Teixeira et al. [214] investigated both conventional mechanical stirring and ultrasonic irradiation of the alkali-catalyzed transesterification of beef tallow. Under similar reaction conditions, ultrasonic treatment $(400 \mathrm{~W}$ and $20 \mathrm{kHz}$ ) could achieve similar FAME in a shorter reaction time $(70 \mathrm{~s})$ compared to $1 \mathrm{~h}$ in the conventional process. In the ethanolysis of coconut oil assisted by ultrasonication [215], $98.3 \mathrm{wt} \%$ FAEE yield was obtained under optimal reaction conditions (oil / ethanol molar ratio 1:6, $0.75 \mathrm{wt} \% \mathrm{KOH}$ to oil, and a reaction time of $7 \mathrm{~min}$ ), while $94 \mathrm{wt} \%$ FAME yield was achieved by conventional stirring at an oil/methanol molar ratio of $1: 8,1 \mathrm{wt} \% \mathrm{KOH}$ to oil, $60{ }^{\circ} \mathrm{C}$ and a reaction time of $120 \mathrm{~min}$ ). It is evident that ultrasonic irradiation could reduce, considerably, consumption of alcohol, amount of catalyst, and time. Hingue et al. [216] illustrated that transesterification of waste cooking oil in sonochemical reactors is a promising new route for biodiesel synthesis. Ultrasound power $200 \mathrm{~W}$ treatment for $40 \mathrm{~min}$ led to an $89.5 \%$ conversion to FAME at 1:6 oil/methanol molar ratio, $1 \mathrm{wt} \% \mathrm{KOH}$ to oil, and a $45{ }^{\circ} \mathrm{C}$ reaction temperature. Compared to conventional stirring (54 blade turbine with diameter $1.5 \mathrm{~cm}$ operating at $1000 \mathrm{rpm}$ ), only $57 \%$ conversion was achieved under optimal conditions. Deng et al. [217] demonstrated that the two-step process, acid esterification and base-transesterification, coupled with ultrasonic irradiation, is an efficient route for biodiesel production with high yields and stability from crude oils with high FFA. A 96.4\% biodiesel yield with only $0.32 \mathrm{mg} \mathrm{KOH} / \mathrm{mg}$ acid value was achieved for Jatropha curcas seed oil with $10.45 \mathrm{mg} \mathrm{KOH} / \mathrm{mg}$, by the new two-step process, in an ultrasonic reactor at $210 \mathrm{~W}$ and $60{ }^{\circ} \mathrm{C}$. The reaction time required for the ultrasonic-assisted two-step process was half of the time required for the conventional two-step process.

Ultrasonic radiation is effective in heterogeneous catalysis as well as in homogenous catalysis. Investigations on transesterification of Jatropha curcas oil by mesoporous solid base catalyst $\left(\mathrm{Na} / \mathrm{SiO}_{2}\right)$ were carried out by Kumar et al. [215]. Maximum biodiesel yield, more than $98 \%$, was obtained under optimal reaction conditions (1:9 oil to methanol molar ratio, catalyst percentage $3 \mathrm{wt} \%$ to oil, ultrasonic wave amplitude $50 \%$, ultrasonic irradiation pulse 0.7 cycle each second, and processing time $15 \mathrm{~min}$ compared to $3-6 \mathrm{~h}$ in conventional methods). The solid catalyst could be reused successfully for three cycles after appropriate thermal treatment. These results indicate that ultrasonic treatment could increase the efficiency of the heterogeneous catalyst. Moreover, optimum conversion can be attained at a lower amount of the catalyst.

Ultrasound-assisted lipase-catalyzed transesterification of triglycerides has also emerged as one of the latest trends in the research efforts concerning the application of ultrasound irradiation for biodiesel production. Batistella et al. [218] studied the influence of ultrasound irradiation on lipase-catalyzed ethanolysis of soybean oil, without agitation, in the presence of hexane as a solvent. They were able to obtain high biodiesel yield $(\approx 90 \mathrm{wt} \%)$ at reaction temperature $60{ }^{\circ} \mathrm{C}$ in a relatively short reaction time, $4 \mathrm{~h}$, by using Lipozyme RM IM as a catalyst. The catalyst was reused successfully for two cycles without significant decay in its activity. The effect of ultrasound irradiation on lipase-catalyzed transesterification in the presence of different solvents and in the absence of solvent, as well as the behavior of the lipase in the ultrasound systems, are hot topics to be investigated by researchers. 


\subsection{Microwave Irradiation Assisted Catalysis}

Microwave radiation can change the magnetic field of weak polar molecules, such as alcohols. As a result, the rotational movement of the molecules is accelerated, and heat is generated. In chemical reactions, microwave irradiation leads to more effective heat transfer than conventional heating in a much shorter reaction time. The major disadvantage or restriction of microwave heating is its shallow penetration depth. The microwave has a few millimeters of penetration depth, indicating a fast reduction in microwave intensity in a reaction setting. The non-thermal effect associated with microwave heating is also debatable. Another difficult issue is choosing suitable building materials because microwave susceptibility in some materials, sparks in metal, and high-temperature zones at welded or sharp edges may all be lethal.

Microwave irradiation is one of the most effective methods to obtain high biodiesel yields in a concise reaction time [219-221]. Azcan and Danisman [222] studied the alkalicatalyzed transesterification of cotton seed oil to compare microwave heating to conventional heating techniques. Three parametric conditions were varied (catalyst amount, temperature, and reaction time). The optimum reaction parameters were found to be $1.5 \%(w / w)$ catalyst to oil, $333 \mathrm{~K}$ temperature, and a seven-minute reaction time to obtain biodiesel with high yield and purity. Similar results were achieved by conventional heating but in a $30 \mathrm{~min}$ reaction time. Perin et al. [223] demonstrated that microwave heating effectively increases the rate of heat transfer in the reaction medium between alcohol and oil in the presence of a solid basic or acidic catalyst and in homogenous catalysis. They used acidic silica gel $\left(\mathrm{SiO}_{2} / 50 \% \mathrm{H}_{2} \mathrm{SO}_{4}\right)$ and basic alumina $\left(\mathrm{Al}_{2} \mathrm{O}_{3} / 50 \% \mathrm{KOH}\right)$ to transesterify castor oil in the presence of methanol or ethanol. The reaction conditions were adjusted to a 1:6 oil to alcohol molar ratio, $10 \mathrm{wt} \%$ catalysts to oil, and a $60^{\circ} \mathrm{C}$ reaction temperature. Conventional heating resulted in high yields after 1 and $3 \mathrm{~h}$ for acidic and basic catalysis, respectively, while microwave heating afforded similar biodiesel yields after 30 and $5 \mathrm{~min}$ for acidic catalysis and basic catalysis.

Combining ultrasound mixing with microwave heating in transesterification of triglycerides increases the mass transfer and heat transfer in the reaction media simultaneously. Therefore, a discrete two-step process was proposed by Hiaso et al. [224] to attain high biodiesel yield and conversion from soybean oil in the presence of methanol and alkaline catalyst. The authors aimed to obtain the optimal ultrasonic mixing and closed microwave irradiation. In the first step, the reaction of reagents was assisted by ultrasound mixing. In the second step, the reaction of reagents was assisted by closed microwave irradiation. A high rate of conversion (97.7\%) was achieved by 1 min ultrasound mixing followed by 2 min closed microwave irradiation at optimal conditions: methanol to oil molar ratio, 6:1; the amount of catalyst, $1.0 \mathrm{wt} \%$; and reaction temperature of $333 \mathrm{~K}$. It is worth mentioning that assisting the reaction in one step within a short time, by ultrasound mixing without microwave irradiation or by microwave irradiation without ultrasound mixing, led to very poor methyl ester conversion. A comparative study of the sequential effect of microwave and ultrasound compared to individual approaches of microwave and ultrasound was carried out by Gole and Gogate [225] to produce biodiesel from high acid value Nagchampa oil. By an individual approach of ultrasound, the initial acid value of the oil was reduced from 18.9 to $1.7 \mathrm{mg} \mathrm{KOH} / \mathrm{g}$ of oil by the optimized condition: methanol to oil molar ratio $1: 4,3 \mathrm{wt} \% \mathrm{H}_{2} \mathrm{SO}_{4}$ to oil, and $60 \mathrm{~min}$ reaction time.

In contrast, the individual microwave approach required a 1:3 methanol to oil molar ratio, $\mathrm{t} 3 \mathrm{wt} \% \mathrm{H}_{2} \mathrm{SO}_{4}$ to oil, and a $25 \mathrm{~min}$ reaction time to achieve the same result. However, the sequential approach of microwave followed by ultrasound, to reduce the acid value in the range, required a considerably smaller methanol to oil ratio, amount of catalyst, and reaction time (1:2 M, $2 \mathrm{wt} \%$, and $15 \mathrm{~min})$, respectively. For the transesterification reaction, ultrasound, microwave, and the sequential approach required (1:6, methanol to oil molar ratio, $1 \mathrm{wt} \% \mathrm{NaOH}$ to oil, and a reaction time of $20 \mathrm{~min}$ at $50{ }^{\circ} \mathrm{C}$ reaction temperature), (1:6 methanol to oil molar ratio, $1 \mathrm{wt} \% \mathrm{NaOH}$ to oil, $350 \mathrm{rpm}$, and $15 \mathrm{~min}$ ), (1:4 methanol to oil molar ratio, $1 \mathrm{wt} \% \mathrm{NaOH}$ to oil, and $6 \mathrm{~min}$ reaction time), respectively. The sequential 
process should start with the microwave since the heat released by the microwave effect accelerates the ultrasonic mixing. In their study, Gole and Gogate [225] illustrated that a sequential combination of microwave and ultrasound is economically more feasible in producing biodiesel because it reduces the amount of the catalyst and the reaction time. Moreover, the requirement of less amount of methanol reduces the consumption of energy in methanol recovery.

\section{Non-Catalytic Biodiesel Production}

The transesterification reaction between supercritical alcohol and triglycerides occurs in the absence of any catalysts. Once the alcohol molecules reach the supercritical region, hydrogen bonding in the alcohol dramatically decreases, allowing alcohol molecules to behave similar to an acid catalyst [226-228]. At particularly high pressure and temperature, for instance, $240{ }^{\circ} \mathrm{C}$ and 78.60 bar, methanol behaves similarly to a supercritical fluid, and the nature is similar to a compressible fluid with an intermediate density between a liquid and a gaseous fluid that allows excellent mass transfer characteristics due to the low surface tension and viscosity. The increase in temperature decreases the ionic product of different polar solvents, such as alcohols, $\mathrm{CO}_{2}$, and water, converting them into a non-polar solvent. Supercritical alcohol technology can eliminate the drawbacks of homogenous and heterogeneous conventional catalytic processes as it does not use any catalyst. At supercritical conditions, alcohol has unique properties, such as gas-like high kinetic energy and liquid-like high density. Furthermore, supercritical alcohol has a low dielectric constant compared to alcohol liquid. This results in a reduced negative effect of alcohol polarity when reacting with the non-polar triglycerides. The process forms an entirely miscible 1-phase system of triglycerides and alcohol, and full conversion to fatty acids alkyl ester is accomplished in a concise time without a catalyst. The process involves heating alcohol until its critical temperature and pressure are reached [229-232]. Table 8 illustrates the critical temperature and pressure of some alcohols and solvents.

Table 8. Critical properties of various alcohols and other solvents [233-236].

\begin{tabular}{ccc}
\hline Alcohol/Solvent & Critical Temperature $\left({ }^{\circ} \mathbf{C}\right)$ & Critical Pressure (MPa) \\
\hline Methanol & 239 & 8.09 \\
Ethanol & 243 & 6.38 \\
1-propanol & 264 & 5.06 \\
1-butanol & 287 & 4.9 \\
1-octanol & 385 & 2.86 \\
Water & 373.95 & 22.12 \\
Methyl acetate & 234 & 4.69 \\
Dimethyl carbonate & 283 & 4.63 \\
Acetic acid & 317 & 5.80 \\
\hline
\end{tabular}

\subsection{One-Step Catalyst-Free Supercritical Alcohol Transesterification}

Saka and Kusdaina [237] studied the production of methyl esters from rapeseed oil using supercritical methanol instead of sodium hydroxide as a catalyst. The authors reported that methyl esters produced in supercritical methanol have similar fatty acid composition comparable to that of the conventional method. Moreover, they reported higher biodiesel yield for the supercritical method compared to biodiesel yield derived using an alkaline catalyst; this can be attributed to simultaneous transesterification and esterification of FFAs. As supercritical alcohol transesterification required a more straightforward purification process, the authors claimed the process to be more environmentally friendly. Alcohol to oil molar ratio, temperature, and alcohol type are the factors that affect this process. Saka and Kusdaina [238] carried out a detailed kinetic study in free catalyst transesterification of rapeseed oil using supercritical methanol. The authors varied the controlling factors, such as temperature and reaction time and methanol to oil molar ratio. The authors reported maximum biodiesel yield at $350^{\circ} \mathrm{C}, 43 \mathrm{MPa}$, and 1:42 methanol to oil molar ratio. Warabi 
et al. [239] reported that, by using supercritical conditions, short-alkyl chain alcohols could achieve 100\% conversion of triglycerides to biodiesel. They also reported a higher FFAs esterification reaction rate compared to triglycerides transesterification rate.

Madras et al. [240] investigated the biodiesel synthesis process under supercritical methanol and ethanol from refined sunflower oil. They observed a nearly complete conversion rate around $80-100 \%$ when the reaction occurred in the presence of supercritical ethanol and methanol, and they reported the transesterification at temperature $200-400{ }^{\circ} \mathrm{C}$, pressure $20 \mathrm{MPa}$ for a molar ratio of 40:1 alcohol to oil molar with a reaction time of $30 \mathrm{~min}$. Moreover, they determined the reaction kinetics and reaction relevant activation energy from temperature relied on the rate coefficients. He et al. [241] examined the continuous biodiesel synthesizing process from soybean oil utilizing supercritical methanolysis by a tube reactor and reported catalyst-free optimum reaction achieved under a constant reaction temperature with an alcohol to oil molar ratio of $40: 1$, under $310^{\circ} \mathrm{C}$, and $35 \mathrm{MPa}$ for 25 min residence time. Their maximum production yield is $77 \%$, and they proposed a gradual heating method and obtained more than $96 \%$ methyl ester conversion.

Hawash et al. [242] reported biodiesel preparation from the transesterification of Jatropha oil, and they used a supercritical methanol catalyst-free process under various test conditions. They maintained a temperature from 512 to $613 \mathrm{~K}$, pressure 5.7 to $8.6 \mathrm{MPa}$, and 10:43 molar ratio of alcohol to fuel. They reported biodiesel from Jatropha oil via supercritical methanol transesterification and reported a $100 \%$ yield in under $4 \mathrm{~min}$ at 320 and 8.4 MPa with a 43:1 molar ratio of methanol to oil. Demirbas et al. [243] examined that 250 and 41:1 molar ratios of methanol to hazelnut kernel oil are suitable to produce biodiesel with a yield of $95 \%$ in $5 \mathrm{~min}$. The free catalyst method necessitates high energy consumption for reaching high reaction pressure-temperature conditions and recovering unreacted alcohol. Santana et al. [244] studied continuous biodiesel production using supercritical ethanol on an ion exchanging resin catalyst with an additional co-solvent carbon-di-oxide for pressure $15-25 \mathrm{MPa}, 150$ to $200^{\circ} \mathrm{C}$, and oil to ethanol molar ratio 1:20 to 1:45 by varying residence time. Micic et al. [245] studied continuous biodiesel production using supercritical ethanol on an ion exchanging resin catalyst with an additional co-solvent carbon-di-oxide for pressures $15-25 \mathrm{MPa}, 150$ to $200{ }^{\circ} \mathrm{C}$, and oil to ethanol molar ratio 1:20 to $1: 45$ by varying residence time.

Water affects the formation of biodiesel in the catalyst-free supercritical methanol process positively. Vegetable oils that contain water, transesterification, hydrolysis of triglycerides, and methyl esterification of fatty acids proceed simultaneously during the treatment and result in high yields [246]. Thus, supercritical methanol transesterification technology is deemed economically more feasible due to higher biodiesel yield in a short reaction time with lower methanol consumption from low feedstock with high FFAs or water contents. Palm fatty acids distillate (PFAD), which is a by-product from palm oil refineries, consists of $93 \%$ FFAs and is esterified by Yujaroen et al. [234] in supercritical methanol conditions. A high biodiesel yield was obtained $(95 \%)$ at $300{ }^{\circ} \mathrm{C}$ with 1:6 PFAD to methanol molar ratio and a $30 \mathrm{~min}$ reaction time. Compared to the transesterification of pure palm oil (PPO) in supercritical methanol, a relatively low biodiesel yield $(80 \%)$ was reached at $300{ }^{\circ} \mathrm{C}$ with higher methanol requirements (1:45 PPO to methanol) and $50 \mathrm{~min}$ reaction time. Acid-catalyzed-esterification of the PFAD produced only $75 \%$ biodiesel yield in a $5 \mathrm{~h}$ reaction time. Wet algae biomass containing $90 \%$ water was converted to biodiesel at much milder reaction conditions, a wet algae to methanol (wt./vol) ratio of 1:9, with a reaction temperature and reaction time of $255^{\circ} \mathrm{C}$ and $25 \mathrm{~min}$, respectively [235]. Hegel et al. [247] used free-catalyst supercritical ethanol transesterification of the bio-oil to obtain biodiesel. The authors reported higher lipid extraction yields using ethanol with respect to n-hexane. The authors further reported that the transesterification of crude lipids extracted with ethanol as the solvent at $305^{\circ} \mathrm{C}$ and $40 \mathrm{~min}$ produced up to $15.9 \mathrm{wt} \%$ of biodiesel with respect to dried biomass processed. 


\subsection{Acyl Acceptors as an Alternative to Alcohol}

Saka and Isayama [248] developed a new method for the transesterification of triglycerides in order to avoid the formation of glycerol as a by-product in biodiesel production. In its supercritical condition, they used methyl acetate to convert triglycerides of rapeseed oil to biodiesel in one step without catalyst. The new by-product was triacetin, which is a valuable biodiesel additive. Triacetin has the ability to improve cloud points and oxidative stability of biodiesel. Patil et al. [249] studied the effect of lipid to methyl acetate molar ratio, reaction temperature, and reaction time on the FAME yield and algal biodiesel fuel yield. The authors concluded that this glycerin-free and non-catalytic transesterification process is more economical and environmentally friendly due to the simplification of the downstream separation and purification process. Tan et al. [250] studied FFAs and water's effect on the supercritical methyl acetate (SCMA) process. PO was treated with a predetermined amount of FFAs and water. Their results conclude that the SCMA process is insensitive to the presence of FFAs or water. FFAs react with methyl acetate to produce FAME and, a by-product, acetic acid, which catalyze the reaction and convert glycerol, as a result of the hydrolysis of the triglycerides to triacetin, simultaneously. Glycerol carbonate and citramalic acid were produced as two other valuable by-products of the non-catalytic one-step transesterification of rapeseed oil by supercritical dimethyl carbonate by Ilaham and Saka [251].

Li et al. [252] first studied ethanol and obtained it as an acyl acceptor during the deacidification of high-acid rice bran oil (RBO) esterification catalysis process through immobilized partial glycerides selective lipase SMG1-F278N from Malassezia globose. The strong specificity of immobilized SMG1-F278N toward MAG and diacylglycerol (DAG) assures the intactness of triacylglycerol (TAG) while converting FAs to FA ethyl esters [252,253]. Sun et al. [254] studied phoenix tree seed oil (PTSO) as the novel feedstock to prepare fatty acid ethyl ester (FAEE), where ethanol as a fatty acyl acceptor and $\mathrm{NaOH}$ as a catalyst and the impact of transesterification conditions are observed in the order of $\mathrm{NaOH}$ concentration $>$ substrate ratio > transesterification temperature. In Li et al. [255], methanol, ethanol, and glycerol were utilized as a novel acyl acceptor by deacidification of high-acid rice bran oil (RBO), and methanol showed a higher deacidification efficiency of RBO compared with glycerol and ethanol due to the distance of glycerol being more distant from catalytic serine (Ser-171) of SMG1-F278N, having a critical distance of approximately $4.6 \AA$. Methanol and ethanol potentially react with fatty acids, and a close distance was observed between them, and they approximately maintained a binding distance of 3.6 and $3.7 \AA$ from the catalytic serine. As a final product, the acid value was $0.09 \mathrm{~g} \mathrm{KOH} / \mathrm{g}$.

\subsection{Production of Biodiesel by Supercritical Technology at Mild Conditions}

Conventional free catalyst supercritical methanol treatment of triglycerides (lipids/oils) is economically not feasible, although they achieve high conversion to FAME, because of the harsh conditions, of high temperature and pressure required, besides the thermal degradation of FAME, especially those with a high unsaturation degree and isomerization of fatty acids to trans-type at high temperatures. Imahara et al. [256] investigated the effect of high temperature and pressure $\left(270{ }^{\circ} \mathrm{C} / 17 \mathrm{MPa}\right.$ to $\left.380^{\circ} \mathrm{C} / 56 \mathrm{MPa}\right)$ on the thermal stability of biodiesel derived from supercritical methanol conditions for various plant oils. Temperatures lower than $300{ }^{\circ} \mathrm{C}$, preferably $270{ }^{\circ} \mathrm{C}$, with a minimum pressure of $8.09 \mathrm{MPa}$, were proven to be appropriate to maintain the maximum yields and thermal stabilization of biodiesel. Therefore, researchers were motivated to develop new supercritical fluid technology to produce biodiesel at mild reaction conditions.

\subsubsection{Supercritical Methanol and Co-Solvent}

According to Yin et al. [257], the presence of propane in the reaction mixture, as a co-solvent, simultaneously reduces the temperature and pressure required for the methanolysis of vegetable oils in supercritical conditions. Propane is a good solvent for vegetable oils. Hence, a single-phase (methanol/oil) can be achieved at a lower temperature and methanol 
to oil molar ratio. The reduction of methanol in the reaction mixture, consequently, reduces the pressure required for a supercritical state. Yin et al. [257], in their study of supercritical methanol reactions with soybean oil, obtained a $98 \%$ biodiesel yield at optimal conditions propane/methanol molar ratio 0.05 , methanol/oil molar ratio 24 , reaction temperature $280{ }^{\circ} \mathrm{C}$, reaction pressure $12.8 \mathrm{MPa}$, and a $10 \mathrm{~min}$ reaction time. Furthermore, propane has the advantage of being reused after some pretreatments.

\subsubsection{Subcritical Methanol and Co-Catalyst}

Some heterogeneous catalysts are capable of transesterifying triglycerides at much milder reaction conditions at subcritical conditions of methanol. A maximum conversion of sunflower oil to biodiesel was achieved at $\left(252{ }^{\circ} \mathrm{C}, 3 \% \mathrm{CaO}\right.$ to the oil weight, $41: 1$ methanol to oil molar ratio, and $6 \mathrm{~min}$ reaction time) [258]. Combining heterogeneous catalysts with subcritical methanol conditions gives more convenient temperature and pressure requirements compared to supercritical methanol-free catalysts. A minimal amount of tri-potassium phosphate in subcritical methanol exhibited high catalytic activity in the transesterification of soybean oil. A maximum biodiesel yield (95.6\%) was obtained at optimal conditions $\left(1 \% \mathrm{~K}_{3} \mathrm{PO}_{4}\right.$ to oil weight, $22{ }^{\circ} \mathrm{C}$, methanol/oil molar ratio $24: 1$ and 30 min reaction time. The catalyst retained $90 \%$ of its initial activity after two cycles [257]. This method was limited by the maximum presence of water and FFA 5\% and 3\%, respectively [257]. More satisfactory results were obtained when soybean oil was treated by subcritical methanol in the presence of a minimal amount of potassium hydroxide $(\mathrm{KOH} /$ oil $=0.1 \mathrm{wt} \%)$ as a catalyst, $98 \%$ biodiesel yield was obtained afte10 $\mathrm{min}$ at $160{ }^{\circ} \mathrm{C}$ and molar ratio (methanol/oil) 24:1 [259].

\subsubsection{Two-Step Supercritical Methanol Transesterification}

Kusdiana and Saka [260] have developed a new two-step process for the methanolysis of triglycerides. The first step involves the hydrolysis of triglycerides at a subcritical state of water. The second step is supercritical methanol treatment of fatty acids (FA) results from the hydrolysis, together with the FFAs, initially exist in the reaction mixture to achieve FAME conversion. The two-step process was applied to convert rapeseed oil to FAME in a considerably shorter reaction time and milder condition $\left(270{ }^{\circ} \mathrm{C} / 7-20 \mathrm{MPa}\right)$ than direct supercritical methanol condition treatment. Furthermore, biodiesel produced by the twostep process has shallow glycerol content due to the continuous reaction removal of glycerol in the first step before the methyl esterification. Detailed kinetic study curried by Minami and Saka [261] revealed that the hydrolysis of triglycerides in a subcritical state of water is an autocatalytic reaction due to the considerable role of the resultant FAs. According to their proposed mechanism, the reaction propagates by the dissociation of the FAs to eliminate proton, which causes the protonation of the carbonyl oxygen of the triglycerides (TG), providing nucleophilic site to be attacked by the water. This theoretical approach coincides very well with experimental results since the FAs yield was observed to be low at the earlier stage of the reaction and increase gradually when the rate of FAs formation increase in the course of time. Ilham and Saka [262] investigated transesterification of Jatropha curcas oil in dimethyl- carbonate supercritical condition, applying the two-step process. More than $97 \%$ biodiesel yield was achieved by subcritical water treatment $\left(270{ }^{\circ} \mathrm{C} / 27 \mathrm{MPa}\right)$ for $25 \mathrm{~min}$ followed by subsequent supercritical dimethyl carbonate treatment $\left(300^{\circ} \mathrm{C} / 9 \mathrm{MPa}\right)$ for $15 \mathrm{~min}$. There was no thermal decomposition of unsaturated fatty acid methyl ester derived from Jatropha curcas, observed.

A novel two-step process to convert triglycerides to biodiesel at mild reaction conditions without glycerol production was developed by Saka et al. [236]. It includes treatment of triglycerides with subcritical acetic acids followed by supercritical methanol treatment. Rapeseed oil was converted in the first step to FA and triacetin by subcritical acetic acid under optimal conditions $\left(300{ }^{\circ} \mathrm{C} / 20 \mathrm{MPa}, 30 \mathrm{~min}\right.$ reaction time, and 1:54 oil to acetic acid molar ratio equivalent to 1:3.2 volumetric ratio). After removal of triacetin from the reaction mixture, supercritical methanol treatment required $270{ }^{\circ} \mathrm{C} / 17 \mathrm{MPa}$ for $15 \mathrm{~min}$ at a 
molar ratio of FAs to methanol 1:14 (1:1.6 volumetric ratio) the yield of FAME was $97 \mathrm{wt} \%$ and that for triacetin was $20 \mathrm{wt} \%$ totally being $117 \mathrm{wt} \%$ out of theoretical value $125 \mathrm{wt} \%$.

\section{In Situ Transesterification}

Conventional biodiesel production involves, prior to esterification/transesterification, extraction and purification of oils from triglycerides-bearing materials. Refined feedstock constitutes $70 \%$ of the total cost of biodiesel because of the required multi-processing stages technologies. In situ transesterification is a route of biodiesel production, which was developed to cut down the cost of biodiesel production. In situ transesterification involves one step of direct extraction and transesterification, in which alcohol acts as solvent extraction and transesterification reagent. In situ transesterification, commonly termed reactive extraction has the advantages of reducing the processing time and the amount of solvent [263-265]. In addition, it is environmentally benign since hazardous air pollutants, such as hexane, can be avoided [266].

Production of biodiesel by direct alkali-catalyzed transesterification of soybeans was examined by Haas et al. [266]. With the aid of thin-layer chromatography, it was apparent that even the brief incubation $(2.5 \mathrm{~h})$ of soy flakes $(5 \mathrm{~g})$ in $15 \mathrm{~mL}$ of alkaline solution $(0.33 \mathrm{~N}$ $\mathrm{NaOH}$ ) and simple alcohol (methanol, ethanol, isopropanol) at $60{ }^{\circ} \mathrm{C}$ resulted in fatty acid alkyl ester, suggesting that this phenomenon is a general one. Quain et al. [267] investigated the in situ transesterification of cottonseed oil by sodium hydroxide. Their study revealed that extraction and conversion of cottonseed oil increased significantly by increasing the amount of the catalyst, methanol loading, reaction time, and decreasing the moisture content and the size of the seed particles. The effect of temperature on biodiesel yield was not significant. A total of $99 \%$ and $98 \%$ of cottonseed oil extraction and conversion, respectively, were achieved by the optimal condition: less than $2 \%$ moisture content in cottonseed flour, $0.3-0.335 \mathrm{~mm}$ particle solid size, 0.1 mole/L methanolic sodium hydroxide solution, 135:1 methanol/oil molar ratio, $40{ }^{\circ} \mathrm{C}$ reaction temperature, and a $3 \mathrm{~h}$ reaction time. The presence of petroleum ether as a co-solvent substantially increased the extraction and conversion of the oil, with the optimal volume ratio of 1:3 ether/methanol. Moreover, the cottonseed oil extraction and conversion remained constant by using a mixture of fresh methanol and recycled methanol with 0.2 ratios (of recycled methanol/total reaction methanol, $v / v)$.

The acidic in situ transesterification process presents as a novel route for direct extraction, esterification, and transesterification of low feedstock with high FFA, instead of the conventional acid-base two-step process. Shuit et al. [268] investigated the feasibility of acidic in situ transesterification of Jatropha curcas L. seeds to biodiesel. Oil extraction efficiency (91.2\%) and FAME yield (99.8\%) was achieved by using seeds with a size less than $0.335 \mathrm{~mm}$ and $\mathrm{n}$-hexane as the co-solvent with the following reaction conditions; reaction temperature $60{ }^{\circ} \mathrm{C}$, reaction period of $24 \mathrm{~h}$, methanol to seed ratio $7.5 \mathrm{~mL} / \mathrm{g}$, and $15 \mathrm{wt} \%$ of $\mathrm{H}_{2} \mathrm{SO}_{4}$. The in-situ transesterification process was used by Ehimen et al. [269] as a cost-reducing scheme for microalgae biodiesel production. They aimed to provide information on the optimal condition required for high biodiesel yield with the least material and energy requirements. The conversion process was monitored by the specific gravity of the biodiesel product, as the specific gravity decreased by increasing the concentration of a lighter FAME. The results revealed that the lowest FAME specific gravity was achieved with increasing methanol to oil molar ratios, temperature, and stirring the reaction vessel. Regarding the effect of moisture, it was found that the oil conversion to biodiesel was completely inhibited by water content beyond 115\% (w/w).

Su et al. [270] examined the feasibility of biological in situ reactive extraction of oilseed with short-chain alkyl acetate for alkyl ester production. Firstly, they demonstrated that methyl acetate and ethyl acetate were capable of extracting oil from Pistacia chinensis Bunge seed and Jatropha curcas L, as well as n-hexane. Crude oil extracted by alkyl acetates had, remarkably, a lower phospholipids content compared to extract of hexane. Afterward, they compared the in situ transesterification versus conventional two-step 
extraction/transesterification in the presence of Novozyme 435 in both cases. The yields of methyl esters and ethyl esters in reactive extraction were considerably higher than those obtained by methanolysis and ethanolysis of the hexane extracted oil. The losses in yields may be attributed to the multi-step operations in the conventional extraction and transesterification, or the possible inhibition of lipase by methanol or ethanol and phospholipids. Furthermore, the effects of solvent, seeds, and seed water content on in situ reactive extraction were investigated. Methyl/ethyl esters' yields decreased by incomplete oil extraction due to the too low ratio of solvent/seed or the excessive dilution caused by higher ratios. Regardless of the kind of seeds or alkyl acetates used, the optimum solvent/seed ratio for high yields was $7.5 \mathrm{~mL} / \mathrm{g}$ at the fixed condition of $5 \mathrm{~g}$ oilseed, $50{ }^{\circ} \mathrm{C}$, $30 \%(w / w)$ Nophozyme 435 to theoretical oil content, $10 \mathrm{~h}$, and $180 \mathrm{rpm}$.

The presence of water in the reaction medium enhances biological activity. However, the excess of water leads to hydrolytic reaction and, consequently, decreases the esters' yields. The highest ester yields were achieved at $4.26 \%$ and $4.62 \%$ water contents for Pistacia chinensis and Jatropha curcas L. seeds, respectively, regardless of the kind of alkyl acetate used, at the established solvent/seed ratio. Su et al. [271], in their further investigations on in situ reactive extraction of Pistacia chinensis and Jatropha curcas L. seeds, demonstrated that short-chain dialkyl carbonates act as not only an extraction solvent but also as a transesterification agent. The optimum solvent/seed ratio for the highest biodiesel yields was $10 \mathrm{~mL} / \mathrm{g}$, at fixed conditions: $5 \mathrm{~g}$ oilseed, $50{ }^{\circ} \mathrm{C}, 10 \%(w / w)$ Novozyme 435 to oil content, $10 \mathrm{~h}$, and $180 \mathrm{rpm}$, regardless of the kinds of seeds and dialkyl carbonates used. Regarding the effect of water content at the optimized solvent/seed ratio, for Pistacia chinensis Bunge seed by using dimethyl carbonate, the highest methyl ester yields were attained at $3.14 \%$ water content. In comparison, the highest ethyl ester yields were attained at $2.34 \%$ by using diethyl carbonate. However, the highest ester yields were achieved at $3.02 \%$ of water content for Jatropha curcas L. seeds regardless of the kind of dialkyl carbonates used. At these optimized conditions, for both seeds, the yields of methyl esters and ethyl esters were almost constant after $24 \mathrm{~h}$, with a rapid increase in the first $16 \mathrm{~h}$.

A combination of supercritical methanol technology with reactive extraction was present as a novel method for producing biodiesel by Lim et al. [272]. They aimed to investigate the feasibility of non-catalytic reactive extraction of Jatropha curcas L. seeds in a high-pressure batch reactor in the presence of n-hexane as a co-solvent. The effects of temperature and the size of the solid particles of Jatropha curcas L. seeds on the FAME yields and the oil extraction efficiency were investigated extensively. The particle size of the seeds varied in the range of $0.5-2.0 \mathrm{~mm}$, and the temperature varied in the range of $200-300^{\circ} \mathrm{C}$. Their study revealed that $\leq 1.0 \mathrm{~mm}$ particle solid size, the reaction temperature of $300^{\circ} \mathrm{C}$, and $240 \mathrm{MPa}$ operational pressure are optimal conditions to achieve maximum extraction efficiency and FAME yield at $10 \mathrm{~mL} / \mathrm{g}$ solvent to seed ratio, $2.5 \mathrm{~mL} / \mathrm{g}$ co-solvent to seed ratio, and relatively short reaction time (45 to $80 \mathrm{~min}$ ). The maximum FAME yield (103.5\%) beyond the theoretical value $(100 \%)$ was due to the excess oil being extracted based on n-hexane soxhlet extraction of Jatropha oilseeds due to the significant effect of the co-solvent at the low temperature.

\section{Perspectives and Challenges}

Homogeneous acid/base catalysis is the most preferred method used to produce biodiesel as they are simple to use and require less time to achieve a complete reaction. In addition, metal ions in ILs are novel methods for the esterification and transesterification of low feedstock with high FFAs. Moreover, TDSP is a suitable route for the utilization of the renewable acyl acceptor, ethanol. Heterogeneous catalysis is the most promising alternative technology to homogenous catalysis. Research is going on to minimize mass transfer problems by using co-solvents or developing superior nano-solid acidic or basic catalysts. Waste-based catalysts are a promising solution to cut down the high cost of analytical-grade chemical catalysts. The industrial waste shells are the sources for $\mathrm{CaO}$ as a base catalyst, whereas cellulosic waste biomass materials are carbon-based solid 
acid catalysts. A bio-heterogeneous catalyst was proven to be efficient in converting the low-quality feedstock to biodiesel. Intensive research is being carried out to avoid lipase inhibition by methanol or glycerol. More research is required to reduce the cost of enzymes and immobilization methods besides the research into the types of the carriers. Further investigation into industrial enzymatic biodiesel production for ensuring viable future options is necessary.

The application of ultrasound irradiation and microwave radiation enhances mass and heat transfer and reduces the time required for the transesterification process compared to conventional stirring and heating systems. More in-depth studies should be performed dealing with the reaction pathway of triglycerides on solid acid catalysts. In addition, more parametric studies are also required for two-step heterogeneous ultrasound-assisted transesterification of non-edible feedstocks with different types of catalyst (enzymatic and nano-catalysts). The influence of different parameters, such as catalyst loading, reactor volume, reactor design, and flow rate, on the behavior of microbubbles in ultrasound synthesis at the pilot or industrial scale also has to be investigated further. The selection of appropriate materials of construction for the reaction vessel, microwave leakage and its harmful effect on the human body, and selection of an appropriate catalyst are some of the challenges in implementing microwave-assisted transesterification that needs addressing.

Supercritical alcohol transesterification represents a neat route for biodiesel production since there is no catalyst used. However, this method is energetically intensive, and it affects the thermal stability of the FAME due to the high temperature and pressure required. Co-solvent, co-catalyst, and subcritical water are being investigated for biodiesel production by supercritical technology at mild reaction conditions. Valuable by-products more than glycerol, such as triacetin, were produced by using supercritical methyl acetate and dimethyl carbonate. Developing an alternative acyl acceptor is a promising aspect of a solvent-free system. For solvent systems, the environmental, friendly, and inexpensive solvent should be sought.

In situ transesterification of the seed oil is expected to substantially reduce biodiesel production's cost since the extraction, degumming, and refining processes could be eliminated, and the methanol can be recycled. However, the solid particle size, the solvent/seed ratio, and water content in the raw materials should be maintained to achieve high biodiesel yields. Recent studies demonstrated that a combination of in situ transesterification and supercritical methanol in the presence of co-solvent produces biodiesel yields beyond the expected theoretical yields.

\section{Conclusions}

Fatty acid methyl ester (FAME), known as biodiesel, is a fuel generated from renewable sources used in traditional compression ignition engines. In response to the need to create sustainable energy supplies and combat climate change, the interest in and development of biofuels has increased dramatically in recent years. The commercial and environmental sustainability of the biodiesel industry is still under debate. There is rapid progress in research to make biodiesel production more cost-effective and environmentally benign. Special attention needs to be given to developing new routes of transesterification that render the utilization of low-quality feedstock feasible for biodiesel production, with fewer downstream processes.

There are many non-edible plant oils used for biodiesel synthesis through the transesterification of lipids. Stable catalysts in terms of catalytic life, recyclability, and reduced cost are essential since they directly influence the total cost of the process. The studies on heterogeneous catalysts primarily focused on evaluating the appropriate oil supply, methanol to oil molar proportion, and measuring the accessibility of catalysts owing to their less expensive and more environmentally beneficial properties since they may be recovered and reused. Solid acid catalysts may convert high free fatty acid (FFA) oils into biodiesel in one step despite their lower reaction rate and side reactions. Nano-heterogeneous catalysts have a large active surface area and excellent selectivity, which increase the reaction rate 
and efficiency of nano-catalyzed transesterification. Given the benefits of homogeneous catalysts (high contact surface) and heterogeneous catalysts (easy selectivity), and if the preparation time is short and the cost is low, nano-catalysts may be the best option in synthesizing biodiesel through transesterification.

Author Contributions: Conceptualization, M.S. and S.M.A.R.; methodology, M.S. and I.M.R.F.; formal analysis, M.S.; investigation, M.S. and I.M.R.F.; writing-original draft preparation, M.S. and S.M.A.R.; writing-review and editing, M.S., M.E.M.S. and I.M.R.F.; supervision, A.A.M. and M.K.A.; project administration, M.S. All authors have read and agreed to the published version of the manuscript.

Funding: This work was supported by the strategic research fund of "School of Information, Systems, and Modelling, Faculty of Engineering and Information Technology, University of Technology Sydney, Ultimo 2007, NSW Australia".

Data Availability Statement: No new data were created or analyzed in this study. Data sharing does not apply to this article.

Conflicts of Interest: The authors declare no conflict of interest.

\begin{tabular}{|c|c|}
\hline $\mathrm{KOCH}_{3}$ & Potassium methanolate \\
\hline $\mathrm{OCH}_{3}$ & Methoxide \\
\hline $\mathrm{KOH}$ & Potassium hydroxide \\
\hline FFA & Free Fatty Acid \\
\hline $\mathrm{H}_{2} \mathrm{SO}_{4}$ & Sulphuric Acid \\
\hline $\mathrm{BMIm}-\mathrm{CH}_{3} \mathrm{SO}_{3}$ & 1-butyl-3 methyl imidazolium- tosylate \\
\hline TDSP & Transesterification Double Step Process \\
\hline NMR & Nuclear Magnetic Resonance \\
\hline $\mathrm{MCM}$ & Mobil Composition of Matter \\
\hline SBA & Santa Barbara Amorphous \\
\hline FAME & Fatty Acid Methyl Ester \\
\hline RFA & Rapeseed oil fatty acids \\
\hline $\mathrm{RO}$ & Rapeseed oil \\
\hline $\mathrm{ACPhSO}_{3} \mathrm{H}$ & 4-sulfophenyl activated carbon-based solid acid catalyst \\
\hline RME & Rapeseed methyl ester \\
\hline GO & Graphene Oxide \\
\hline $\mathrm{SO}_{3}$ & Sulfur trioxide \\
\hline THF & tetrahydrofuran \\
\hline DMSO & dimethylsulfoxide \\
\hline DEE & Diethyl ether \\
\hline KF & Potassium Fluoride \\
\hline XRD & X-ray diffractometer \\
\hline $\mathrm{CH}_{3} \mathrm{OH}$ & Methanol \\
\hline $\mathrm{O}_{2}$ & Oxygen \\
\hline YSA & Yeast residue-based solid acid \\
\hline TGA & Thermogravimetric analysis \\
\hline $\mathrm{CPO}$ & Crude palm oil \\
\hline BSP & Biomass Support Particles \\
\hline FAEE & Fatty Acid Ethyl Ester \\
\hline
\end{tabular}

\section{References}

1. Hussain, F.; Soudagar, M.E.M.; Afzal, A.; Mujtaba, M.; Fattah, I.M.R.; Naik, B.; Mulla, M.H.; Badruddin, I.A.; Khan, T.M.Y.; Raju, V.D.; et al. Enhancement in Combustion, Performance, and Emission Characteristics of a Diesel Engine Fueled with Ce-ZnO Nanoparticle Additive Added to Soybean Biodiesel Blends. Energies 2020, 13, 4578. [CrossRef]

2. Gavhane, R.S.; Kate, A.M.; Soudagar, M.E.M.; Wakchaure, V.D.; Balgude, S.; Fattah, I.M.R.; Nik-Ghazali, N.-N.; Fayaz, H.; Khan, T.M.Y.; Mujtaba, M.A.; et al. Influence of Silica Nano-Additives on Performance and Emission Characteristics of Soybean Biodiesel Fuelled Diesel Engine. Energies 2021, 14, 1489. [CrossRef] 
3. Razzaq, L.; Mujtaba, M.A.; Soudagar, M.E.M.; Ahmed, W.; Fayaz, H.; Bashir, S.; Fattah, I.M.R.; Ong, H.C.; Shahapurkar, K.; Afzal, A.; et al. Engine performance and emission characteristics of palm biodiesel blends with graphene oxide nanoplatelets and dimethyl carbonate additives. J. Environ. Manag. 2021, 282, 111917. [CrossRef] [PubMed]

4. Karmakar, B.; Halder, G. Progress and future of biodiesel synthesis: Advancements in oil extraction and conversion technologies. Energy Convers. Manag. 2019, 182, 307-339. [CrossRef]

5. Fattah, I.M.R.; Masjuki, H.H.; Liaquat, A.M.; Ramli, R.; Kalam, M.A.; Riazuddin, V.N. Impact of various biodiesel fuels obtained from edible and non-edible oils on engine exhaust gas and noise emissions. Renew. Sustain. Energy Rev. 2013, 18, 552-567. [CrossRef]

6. Palash, S.M.; Kalam, M.A.; Masjuki, H.H.; Masum, B.M.; Rizwanul Fattah, I.M.; Mofijur, M. Impacts of biodiesel combustion on NOx emissions and their reduction approaches. Renew. Sustain. Energy Rev. 2013, 23, 473-490. [CrossRef]

7. Imtenan, S.; Varman, M.; Masjuki, H.H.; Kalam, M.A.; Sajjad, H.; Arbab, M.I.; Rizwanul Fattah, I.M. Impact of low temperature combustion attaining strategies on diesel engine emissions for diesel and biodiesels: A review. Energy Convers. Manag. 2014, 80, 329-356. [CrossRef]

8. Fattah, I.M.R.; Masjuki, H.H.; Kalam, M.A.; Hazrat, M.A.; Masum, B.M.; Imtenan, S.; Ashraful, A.M. Effect of antioxidants on oxidation stability of biodiesel derived from vegetable and animal based feedstocks. Renew. Sustain. Energy Rev. 2014, 30, 356-370. [CrossRef]

9. Rahman, S.M.A.; Fattah, I.M.R.; Ong, H.C.; Ashik, F.R.; Hassan, M.M.; Murshed, M.T.; Imran, M.A.; Rahman, M.H.; Rahman, M.A.; Hasan, M.A.M.; et al. State-of-the-Art of Establishing Test Procedures for Real Driving Gaseous Emissions from Light- and Heavy-Duty Vehicles. Energies 2021, 14, 4195. [CrossRef]

10. Rahman, S.M.A.; Rizwanul Fattah, I.M.; Ong, H.C.; Zamri, M.F.M.A. State-of-the-Art of Strategies to Reduce Exhaust Emissions from Diesel Engine Vehicles. Energies 2021, 14, 1766. [CrossRef]

11. Liaquat, A.M.; Masjuki, H.H.; Kalam, M.A.; Rizwanul Fattah, I.M. Impact of biodiesel blend on injector deposit formation. Energy 2014, 72, 813-823. [CrossRef]

12. Gulzar, M.; Masjuki, H.H.; Kalam, M.A.; Varman, M.; Rizwanul Fattah, I.M. Oil filter modification for biodiesel-fueled engine: A pathway to lubricant sustainability and exhaust emissions reduction. Energy Convers. Manag. 2015, 91, 168-175. [CrossRef]

13. Severo, I.A.; Siqueira, S.F.; Deprá, M.C.; Maroneze, M.M.; Zepka, L.Q.; Jacob-Lopes, E.J.R.; Reviews, S.E. Biodiesel facilities: What can we address to make biorefineries commercially competitive? Renew. Sustain. Energy Rev. 2019, 112, 686-705. [CrossRef]

14. Imtenan, S.; Masjuki, H.H.; Varman, M.; Rizwanul Fattah, I.M.; Sajjad, H.; Arbab, M.I. Effect of n-butanol and diethyl ether as oxygenated additives on combustion-emission-performance characteristics of a multiple cylinder diesel engine fuelled with diesel-jatropha biodiesel blend. Energy Convers. Manag. 2015, 94, 84-94. [CrossRef]

15. Imtenan, S.; Masjuki, H.H.; Varman, M.; Rizwanul Fattah, I.M. Evaluation of n-butanol as an oxygenated additive to improve combustion-emission-performance characteristics of a diesel engine fuelled with a diesel-calophyllum inophyllum biodiesel blend. RSC Adv. 2015, 5, 17160-17170. [CrossRef]

16. Demirbas, A.; Bafail, A.; Ahmad, W.; Sheikh, M. Biodiesel production from non-edible plant oils. Energy Explor. Exploit. 2016, 34, 290-318. [CrossRef]

17. Rahman, S.M.A.; Fattah, I.M.R.; Maitra, S.; Mahlia, T.M.I. A ranking scheme for biodiesel underpinned by critical physicochemical properties. Energy Convers. Manag. 2021, 229, 113742. [CrossRef]

18. Abedin, M.J.; Masjuki, H.H.; Kalam, M.A.; Varman, M.; Arbab, M.I.; Rizwanul Fattah, I.M.; Masum, B.M. Experimental Investigation of a Multicylinder Unmodified Diesel Engine Performance, Emission, and Heat Loss Characteristics Using Different Biodiesel Blends: Rollout of B10 in Malaysia. Sci. World J. 2014, 2014, 349858. [CrossRef] [PubMed]

19. Arbab, M.I.; Varman, M.; Masjuki, H.H.; Kalam, M.A.; Imtenan, S.; Sajjad, H.; Rizwanul Fattah, I.M. Evaluation of combustion, performance, and emissions of optimum palm-coconut blend in turbocharged and non-turbocharged conditions of a diesel engine. Energy Convers. Manag. 2015, 90, 111-120. [CrossRef]

20. Arumugam, A.; Ponnusami, V.J.R.E. Biodiesel production from Calophyllum inophyllum oil a potential non-edible feedstock: An overview. Renew. Energy 2019, 131, 459-471. [CrossRef]

21. Mujtaba, M.A.; Masjuki, H.H.; Kalam, M.A.; Noor, F.; Farooq, M.; Ong, H.C.; Gul, M.; Soudagar, M.E.M.; Bashir, S.; Fattah, I.M.R.; et al. Effect of Additivized Biodiesel Blends on Diesel Engine Performance, Emission, Tribological Characteristics, and Lubricant Tribology. Energies 2020, 13, 3375. [CrossRef]

22. Su, G.; Ong, H.C.; Ibrahim, S.; Fattah, I.M.R.; Mofijur, M.; Chong, C.T. Valorisation of medical waste through pyrolysis for a cleaner environment: Progress and challenges. Environ. Pollut. 2021, 279, 116934. [CrossRef]

23. Hoang, A.T.; Ong, H.C.; Fattah, I.M.R.; Chong, C.T.; Cheng, C.K.; Sakthivel, R.; Ok, Y.S. Progress on the lignocellulosic biomass pyrolysis for biofuel production toward environmental sustainability. Fuel Process. Technol. 2021, 223, 106997. [CrossRef]

24. Jogarao, B.; Kumari, A.S. Biodiesel Production Using Second-Generation Feedstocks: A Review. In Recent Advances in Material Sciences; Springer: Berlin/Heidelberg, Germany, 2019; pp. 693-709.

25. Habibullah, M.; Rizwanul Fattah, I.M.; Masjuki, H.H.; Kalam, M.A. Effects of Palm-Coconut Biodiesel Blends on the Performance and Emission of a Single-Cylinder Diesel Engine. Energy Fuels 2015, 29, 734-743. [CrossRef]

26. Demirbaş, A. Biodiesel from vegetable oils via transesterification in supercritical methanol. Energy Convers. Manag. 2002, 43, 2349-2356. [CrossRef] 
27. Dewangan, A.; Yadav, A.K.; Mallick, A.; Pal, A.; Singh, S. Comparative study of Manilkara zapota and Karanja based biodiesel properties and its effect on diesel engine characteristics. In Energy Sources, Part A: Recovery, Utilization, and Environmental Effects; Informa UK Limited: London, UK, 2019; pp. 1-11.

28. Hidayat, A.; Chafidz, A.; Sutrisno, B. Utilization of Modified Coal Fly Ash (CFA) as a Catalyst for Production of Biodiesel from Coconut Oil: Part 1-Characteristics of the Catalyst. Mater. Sci. Forum 2020, 981, 190-195. [CrossRef]

29. Habibullah, M.; Masjuki, H.H.; Kalam, M.A.; Rizwanul Fattah, I.M.; Ashraful, A.M.; Mobarak, H.M. Biodiesel production and performance evaluation of coconut, palm and their combined blend with diesel in a single-cylinder diesel engine. Energy Convers. Manag. 2014, 87, 250-257. [CrossRef]

30. Fattah, I.M.R.; Masjuki, H.H.; Kalam, M.A.; Wakil, M.A.; Ashraful, A.M.; Shahir, S.A. Experimental investigation of performance and regulated emissions of a diesel engine with Calophyllum inophyllum biodiesel blends accompanied by oxidation inhibitors. Energy Convers. Manag. 2014, 83, 232-240. [CrossRef]

31. Marín-Suárez, M.; Méndez-Mateos, D.; Guadix, A.; Guadix, E.M.J.R.E. Reuse of immobilized lipases in the transesterification of waste fish oil for the production of biodiesel. Renew. Energy 2019, 140, 1-8. [CrossRef]

32. Rezania, S.; Oryani, B.; Park, J.; Hashemi, B.; Yadav, K.K.; Kwon, E.E.; Hur, J.; Cho, J. Review on transesterification of non-edible sources for biodiesel production with a focus on economic aspects, fuel properties and by-product applications. Energy Convers. Manag. 2019, 201, 112155. [CrossRef]

33. Singh, S.P.; Singh, D. Biodiesel production through the use of different sources and characterization of oils and their esters as the substitute of diesel: A review. Renew. Sustain. Energy Rev. 2010, 14, 200-216. [CrossRef]

34. Okwundu, O.S.; El-Shazly, A.H.; Elkady, M. Comparative effect of reaction time on biodiesel production from low free fatty acid beef tallow: A definition of product yield. SN Appl. Sci. 2019, 1, 140. [CrossRef]

35. Wang, Y.-T.; Yang, C.-H.; Huang, T.-Y.; Tai, M.-H.; Sie, R.-H.; Shaw, J.-F. Cytotoxic Effects of Chlorophyllides in Ethanol Crude Extracts from Plant Leaves. Evid.-Based Complement. Altern. Med. 2019, 2019, 9494328. [CrossRef] [PubMed]

36. Makareviciene, V.; Janulis, P. Environmental effect of rapeseed oil ethyl ester. Renew. Energy 2003, 28, 2395-2403. [CrossRef]

37. da Silva, M.A.V.; Ferreira, B.L.G.; da Costa Marques, L.G.; Murta, A.L.S.; de Freitas, M.A.V. Comparative study of NOx emissions of biodiesel-diesel blends from soybean, palm and waste frying oils using methyl and ethyl transesterification routes. Fuel 2017, 194, 144-156. [CrossRef]

38. Mendow, G.; Veizaga, N.S.; Sánchez, B.S.; Querini, C.A. Biodiesel production by two-stage transesterification with ethanol. Bioresour. Technol. 2011, 102, 10407-10413. [CrossRef]

39. Atabani, A.E.; Silitonga, A.S.; Badruddin, I.A.; Mahlia, T.M.I.; Masjuki, H.H.; Mekhilef, S. A comprehensive review on biodiesel as an alternative energy resource and its characteristics. Renew. Sustain. Energy Rev. 2012, 16, 2070-2093. [CrossRef]

40. Liu, H.; Wei, L.; Liu, F.; Pei, Z.; Shi, J.; Wang, Z.-J.; He, D.; Chen, Y. Homogeneous, heterogeneous, and biological catalysts for electrochemical N2 reduction toward $\mathrm{NH}_{3}$ under ambient conditions. ACS Catal. 2019, 9, 5245-5267. [CrossRef]

41. Furuta, S.; Matsuhashi, H.; Arata, K. Biodiesel fuel production with solid superacid catalysis in fixed bed reactor under atmospheric pressure. Catal. Commun. 2004, 5, 721-723. [CrossRef]

42. Canakci, M.; Van Gerpen, J. A Pilot Plant to Produce Biodiesel from High Free Fatty Acid Feedstocks. In 2001 ASAE Annual Meeting; American Society of Agricultural and Biological Engineers: St. Joseph, MI, USA, 1998.

43. Demirbaş, A. Biodiesel fuels from vegetable oils via catalytic and non-catalytic supercritical alcohol transesterifications and other methods: A survey. Energy Convers. Manag. 2003, 44, 2093-2109. [CrossRef]

44. Fukuda, H.; Kondo, A.; Noda, H. Biodiesel fuel production by transesterification of oils. J. Biosci. Bioeng. 2001, 92, 405-416. [CrossRef]

45. Ma, F.; Hanna, M.A. Biodiesel production: A review. Bioresour. Technol. 1999, 70, 1-15. [CrossRef]

46. Fattah, I.M.R.; Masjuki, H.H.; Kalam, M.A.; Mofijur, M.; Abedin, M.J. Effect of antioxidant on the performance and emission characteristics of a diesel engine fueled with palm biodiesel blends. Energy Convers. Manag. 2014, 79, 265-272. [CrossRef]

47. Chumuang, N.; Punsuvon, V. Application of calcium methoxide as solid base catalyst for biodiesel production from waste cooking oil. In Key Engineering Materials; Trans Tech Publications Ltd.: Zurich, Switzerland, 2017; pp. 594-598.

48. Asl, M.A.; Tahvildari, K.; Bigdeli, T.J.F. Eco-friendly synthesis of biodiesel from WCO by using electrolysis technique with graphite electrodes. Fuel 2020, 270, 117582.

49. Vicente, G.; Martínez, M.; Aracil, J. Integrated biodiesel production: A comparison of different homogeneous catalysts systems. Bioresour. Technol. 2004, 92, 297-305. [CrossRef]

50. Singh, A.; He, B.; Thompson, J.; Gerpen, J.V. Process optimization of biodiesel production using alkaline catalysts. Appl. Eng. Agric. 2006, 22, 597-600. [CrossRef]

51. Schuchardt, U.; Sercheli, R.; Vargas, R.M. Transesterification of vegetable oils: A review. J. Braz. Chem. Soc. 1998, 9, 199-210. [CrossRef]

52. Fattah, I.M.R.; Ong, H.C.; Mahlia, T.M.I.; Mofijur, M.; Silitonga, A.S.; Rahman, S.M.A.; Ahmad, A. State of the Art of Catalysts for Biodiesel Production. Front. Energy Res. 2020, 8, 101. [CrossRef]

53. Lotero, E.; Liu, Y.; Lopez, D.E.; Suwannakarn, K.; Bruce, D.A.; Goodwin, J.G. Synthesis of Biodiesel via Acid Catalysis. Ind. Eng. Chem. Res. 2005, 44, 5353-5363. [CrossRef]

54. Kouzu, M.; Kasuno, T.; Tajika, M.; Sugimoto, Y.; Yamanaka, S.; Hidaka, J. Calcium oxide as a solid base catalyst for transesterification of soybean oil and its application to biodiesel production. Fuel 2008, 87, 2798-2806. [CrossRef] 
55. Shahir, S.A.; Masjuki, H.H.; Kalam, M.A.; Imran, A.; Rizwanul Fattah, I.M.; Sanjid, A. Feasibility of diesel-biodieselethanol/bioethanol blend as existing CI engine fuel: An assessment of properties, material compatibility, safety and combustion. Renew. Sustain. Energy Rev. 2014, 32, 379-395. [CrossRef]

56. Marchetti, J.M.; Miguel, V.U.; Errazu, A.F. Possible methods for biodiesel production. Renew. Sustain. Energy Rev. 2007, 11, 1300-1311. [CrossRef]

57. Fattah, I.M.R.; Masjuki, H.H.; Kalam, M.A.; Wakil, M.A.; Rashedul, H.K.; Abedin, M.J. Performance and emission characteristics of a CI engine fueled with Cocos nucifera and Jatropha curcas B20 blends accompanying antioxidants. Ind. Crops Prod. 2014, 57, 132-140. [CrossRef]

58. Fattah, I.M.R.; Kalam, M.A.; Masjuki, H.H.; Wakil, M.A. Biodiesel production, characterization, engine performance, and emission characteristics of Malaysian Alexandrian laurel oil. RSC Adv. 2014, 4, 17787-17796. [CrossRef]

59. Demirbas, A. Comparison of transesterification methods for production of biodiesel from vegetable oils and fats. Energy Convers. Manag. 2008, 49, 125-130. [CrossRef]

60. Soriano, N.U.; Venditti, R.; Argyropoulos, D.S. Biodiesel synthesis via homogeneous Lewis acid-catalyzed transesterification. Fuel 2009, 88, 560-565. [CrossRef]

61. Zheng, S.; Kates, M.; Dubé, M.A.; McLean, D.D. Acid-catalyzed production of biodiesel from waste frying oil. Biomass Bioenergy 2006, 30, 267-272. [CrossRef]

62. Freedman, B.; Pryde, E.H.; Mounts, T.L. Variables affecting the yields of fatty esters from transesterified vegetable oils. J. Am. Oil Chem. Soc. 1984, 61, 1638-1643. [CrossRef]

63. Crabbe, E.; Nolasco-Hipolito, C.; Kobayashi, G.; Sonomoto, K.; Ishizaki, A. Biodiesel production from crude palm oil and evaluation of butanol extraction and fuel properties. Process Biochem. 2001, 37, 65-71. [CrossRef]

64. Zhang, Y.; Dubé, M.A.; McLean, D.D.; Kates, M. Biodiesel production from waste cooking oil: 1. Process design and technological assessment. Bioresour. Technol. 2003, 89, 1-16. [CrossRef]

65. Zhang, Y.; Dubé, M.A.; McLean, D.D.; Kates, M. Biodiesel production from waste cooking oil: 2. Economic assessment and sensitivity analysis. Bioresour. Technol. 2003, 90, 229-240. [CrossRef]

66. Juan, J.C.; Kartika, D.A.; Wu, T.Y.; Hin, T.-Y.Y. Biodiesel production from jatropha oil by catalytic and non-catalytic approaches: An overview. Bioresour. Technol. 2011, 102, 452-460. [CrossRef]

67. Ashraful, A.M.; Masjuki, H.H.; Kalam, M.A.; Rizwanul Fattah, I.M.; Imtenan, S.; Shahir, S.A.; Mobarak, H.M. Production and comparison of fuel properties, engine performance, and emission characteristics of biodiesel from various non-edible vegetable oils: A review. Energy Convers. Manag. 2014, 80, 202-228. [CrossRef]

68. Mofijur, M.; Masjuki, H.H.; Kalam, M.A.; Atabani, A.E.; Rizwanul Fattah, I.M.; Mobarak, H.M. Comparative evaluation of performance and emission characteristics of Moringa oleifera and Palm oil based biodiesel in a diesel engine. Ind. Crops Prod. 2014, 53, 78-84. [CrossRef]

69. Wakil, M.A.; Kalam, M.A.; Masjuki, H.H.; Rizwanul Fattah, I.M.; Masum, B.M. Evaluation of rice bran, sesame and moringa oils as feasible sources of biodiesel and the effect of blending on their physicochemical properties. RSC Adv. 2014, 4, 56984-56991. [CrossRef]

70. Charoenchaitrakool, M.; Thienmethangkoon, J. Statistical optimization for biodiesel production from waste frying oil through two-step catalyzed process. Fuel Process. Technol. 2011, 92, 112-118. [CrossRef]

71. Ghadge, S.V.; Raheman, H. Biodiesel production from mahua (Madhuca indica) oil having high free fatty acids. Biomass Bioenergy 2005, 28, 601-605. [CrossRef]

72. Ong, H.C.; Tiong, Y.W.; Goh, B.H.H.; Gan, Y.Y.; Mofijur, M.; Fattah, I.M.R.; Chong, C.T.; Alam, M.A.; Lee, H.V.; Silitonga, A.S.; et al. Recent advances in biodiesel production from agricultural products and microalgae using ionic liquids: Opportunities and challenges. Energy Convers. Manag. 2021, 228, 113647. [CrossRef]

73. Ullah, Z.; Khan, A.S.; Muhammad, N.; Ullah, R.; Alqahtani, A.S.; Shah, S.N.; Ghanem, O.B.; Bustam, M.A.; Man, Z. A review on ionic liquids as perspective catalysts in transesterification of different feedstock oil into biodiesel. J. Mol. Liq. 2018, 266, 673-686. [CrossRef]

74. Guo, F.; Fang, Z.; Tian, X.-F.; Long, Y.-D.; Jiang, L.-Q. One-step production of biodiesel from Jatropha oil with high-acid value in ionic liquids. Bioresour. Technol. 2011, 102, 6469-6472. [CrossRef]

75. Phromphithak, S.; Meepowpan, P.; Shimpalee, S.; Tippayawong, N. Transesterification of palm oil into biodiesel using ChOH ionic liquid in a microwave heated continuous flow reactor. Renew. Energy 2020, 154, 925-936. [CrossRef]

76. D’Oca, M.G.M.; Haertel, P.L.; de Moraes, D.C.; Callegaro, F.J.P.; Kurz, M.H.S.; Primel, E.G.; Clementin, R.M.; Morón-Villarreyes, J.A. Base/acid-catalyzed FAEE production from hydroxylated vegetable oils. Fuel 2011, 90, 912-916. [CrossRef]

77. Samios, D.; Pedrotti, F.; Nicolau, A.; Reiznautt, Q.B.; Martini, D.D.; Dalcin, F.M. A Transesterification Double Step Process-TDSP for biodiesel preparation from fatty acids triglycerides. Fuel Process. Technol. 2009, 90, 599-605. [CrossRef]

78. Guzatto, R.; de Martini, T.L.; Samios, D. The use of a modified TDSP for biodiesel production from soybean, linseed and waste cooking oil. Fuel Process. Technol. 2011, 92, 2083-2088. [CrossRef]

79. Sani, Y.M.; Daud, W.M.A.W.; Abdul Aziz, A.R. Activity of solid acid catalysts for biodiesel production: A critical review. Appl. Catal. A Gen. 2014, 470, 140-161. [CrossRef]

80. Kafuku, G.; Lam, M.K.; Kansedo, J.; Lee, K.T.; Mbarawa, M. Heterogeneous catalyzed biodiesel production from Moringa oleifera oil. Fuel Process. Technol. 2010, 91, 1525-1529. [CrossRef] 
81. Endalew, A.K.; Kiros, Y.; Zanzi, R. Heterogeneous catalysis for biodiesel production from Jatropha curcas oil (JCO). Energy 2011, 36, 2693-2700. [CrossRef]

82. Lee, J.-S.; Saka, S. Biodiesel production by heterogeneous catalysts and supercritical technologies. Bioresour. Technol. 2010, 101, 7191-7200. [CrossRef] [PubMed]

83. Samart, C.; Chaiya, C.; Reubroycharoen, P. Biodiesel production by methanolysis of soybean oil using calcium supported on mesoporous silica catalyst. Energy Convers. Manag. 2010, 51, 1428-1431. [CrossRef]

84. Liang, C.; Wei, M.-C.; Tseng, H.-H.; Shu, E.-C. Synthesis and characterization of the acidic properties and pore texture of Al-SBA-15 supports for the canola oil transesterification. Chem. Eng. J. 2013, 223, 785-794. [CrossRef]

85. Chen, W.-K.; Tseng, H.-H.; Wei, M.-C.; Su, E.-C.; Chiu, I.C. Transesterification of canola oil as biodiesel over Na/Zr-SBA-15 catalysts: Effect of zirconium content. Int. J. Hydrog. Energy 2014, 39, 19555-19562. [CrossRef]

86. Sandesh, S.; Kristachar, P.K.R.; Manjunathan, P.; Halgeri, A.B.; Shanbhag, G.V. Synthesis of biodiesel and acetins by transesterification reactions using novel $\mathrm{CaSn}(\mathrm{OH}) 6$ heterogeneous base catalyst. Appl. Catal. A Gen. 2016, 523, 1-11. [CrossRef]

87. Yadav, M.; Sharma, Y.C. Transesterification of used vegetable oil using $\mathrm{BaAl}_{2} \mathrm{O}_{4}$ spinel as heterogeneous base catalyst. Energy Convers. Manag. 2019, 198, 111795. [CrossRef]

88. Lee, J.H.; Jeon, H.; Park, J.T.; Kim, J.H. Synthesis of hierarchical flower-shaped hollow MgO microspheres via ethylene-glycolmediated process as a base heterogeneous catalyst for transesterification for biodiesel production. Biomass Bioenergy 2020, 142, 105788. [CrossRef]

89. Melero, J.A.; Bautista, L.F.; Morales, G.; Iglesias, J.; Briones, D. Biodiesel Production with Heterogeneous Sulfonic AcidFunctionalized Mesostructured Catalysts. Energy Fuels 2009, 23, 539-547. [CrossRef]

90. Malins, K.; Kampars, V.; Brinks, J.; Neibolte, I.; Murnieks, R. Synthesis of activated carbon based heterogenous acid catalyst for biodiesel preparation. Appl. Catal. B Environ. 2015, 176-177, 553-558. [CrossRef]

91. Bhatia, S.K.; Gurav, R.; Choi, T.-R.; Kim, H.J.; Yang, S.-Y.; Song, H.-S.; Park, J.Y.; Park, Y.-L.; Han, Y.-H.; Choi, Y.-K.; et al. Conversion of waste cooking oil into biodiesel using heterogenous catalyst derived from cork biochar. Bioresour. Technol. 2020, 302, 122872. [CrossRef] [PubMed]

92. Veljković, V.B.; Lakićević, S.H.; Stamenković, O.S.; Todorović, Z.B.; Lazić, M.L. Biodiesel production from tobacco (Nicotiana tabacum L.) seed oil with a high content of free fatty acids. Fuel 2006, 85, 2671-2675. [CrossRef]

93. Wang, Y.; Ou, S.; Liu, P.; Xue, F.; Tang, S. Comparison of two different processes to synthesize biodiesel by waste cooking oil. J. Mol. Catal. A Chem. 2006, 252, 107-112. [CrossRef]

94. Zhang, J.; Chen, S.; Yang, R.; Yan, Y. Biodiesel production from vegetable oil using heterogenous acid and alkali catalyst. Fuel 2010, 89, 2939-2944. [CrossRef]

95. Faruque, M.O.; Razzak, S.A.; Hossain, M.M. Application of Heterogeneous Catalysts for Biodiesel Production from Microalgal Oil-A Review. Catalysts 2020, 10, 1025. [CrossRef]

96. Wang, A.; Li, H.; Zhang, H.; Pan, H.; Yang, S. Efficient Catalytic Production of Biodiesel with Acid-Base Bifunctional Rod-Like Ca-B Oxides by the Sol-Gel Approach. Materials 2019, 12, 83. [CrossRef] [PubMed]

97. Lee, H.V.; Juan, J.C.; Taufiq-Yap, Y.H. Preparation and application of binary acid-base $\mathrm{CaO}-\mathrm{La}_{2} \mathrm{O}_{3}$ catalyst for biodiesel production Renew. Energy 2015, 74, 124-132. [CrossRef]

98. AbdelDayem, H.M.; Salib, B.G.; El-Hosiny, F.I. Facile synthesis of hydrothermal stable hierarchically macro-mesoporous hollow microspheres $\gamma-\mathrm{Al}_{2} \mathrm{O}_{3}$-graphene oxide composite: As a new efficient acid-base catalyst for transesterification reaction for biodiesel production. Fuel 2020, 277, 118106. [CrossRef]

99. Muñoz, R.; González, A.; Valdebenito, F.; Ciudad, G.; Navia, R.; Pecchi, G.; Azócar, L. Fly ash as a new versatile acid-base catalyst for biodiesel production. Renew. Energy 2020, 162, 1931-1939. [CrossRef]

100. Ruhul, A.M.; Kalam, M.A.; Masjuki, H.H.; Fattah, I.M.R.; Reham, S.S.; Rashed, M.M. State of the art of biodiesel production processes: A review of the heterogeneous catalyst. RSC Adv. 2015, 5, 101023-101044. [CrossRef]

101. Leung, D.Y.C.; Wu, X.; Leung, M.K.H. A review on biodiesel production using catalyzed transesterification. Appl. Energy 2010, 87, 1083-1095. [CrossRef]

102. Zabeti, M.; Wan Daud, W.M.A.; Aroua, M.K. Activity of solid catalysts for biodiesel production: A review. Fuel Process. Technol. 2009, 90, 770-777. [CrossRef]

103. Kim, H.-J.; Kang, B.-S.; Kim, M.-J.; Park, Y.M.; Kim, D.-K.; Lee, J.-S.; Lee, K.-Y. Transesterification of vegetable oil to biodiesel using heterogeneous base catalyst. Catal. Today 2004, 93-95, 315-320. [CrossRef]

104. Lam, M.K.; Lee, K.T. Accelerating transesterification reaction with biodiesel as co-solvent: A case study for solid acid sulfated tin oxide catalyst. Fuel 2010, 89, 3866-3870. [CrossRef]

105. Hashemzadeh Gargari, M.; Sadrameli, S.M. Investigating continuous biodiesel production from linseed oil in the presence of a Co-solvent and a heterogeneous based catalyst in a packed bed reactor. Energy 2018, 148, 888-895. [CrossRef]

106. Hájek, M.; Vávra, A.; Mück, J. Butanol as a co-solvent for transesterification of rapeseed oil by methanol under homogeneous and heterogeneous catalyst. Fuel 2020, 277, 118239. [CrossRef]

107. White, R.J.; Luque, R.; Budarin, V.L.; Clark, J.H.; Macquarrie, D.J. Supported metal nanoparticles on porous materials. Methods and applications. Chem. Soc. Rev. 2009, 38, 481-494. [CrossRef] 
108. Mofijur, M.; Siddiki, S.Y.A.; Shuvho, M.B.A.; Djavanroodi, F.; Fattah, I.M.R.; Ong, H.C.; Chowdhury, M.A.; Mahlia, T.M.I. Effect of nanocatalysts on the transesterification reaction of first, second and third generation biodiesel sources-A mini-review. Chemosphere 2021, 270, 128642. [CrossRef] [PubMed]

109. Changmai, B.; Vanlalveni, C.; Ingle, A.P.; Bhagat, R.; Rokhum, S.L. Widely used catalysts in biodiesel production: A review. RSC Adv. 2020, 10, 41625-41679. [CrossRef]

110. Wen, L.; Wang, Y.; Lu, D.; Hu, S.; Han, H. Preparation of KF/CaO nanocatalyst and its application in biodiesel production from Chinese tallow seed oil. Fuel 2010, 89, 2267-2271. [CrossRef]

111. Degirmenbasi, N.; Coskun, S.; Boz, N.; Kalyon, D.M. Biodiesel synthesis from canola oil via heterogeneous catalysis using functionalized CaO nanoparticles. Fuel 2015, 153, 620-627. [CrossRef]

112. Nayebzadeh, H.; Saghatoleslami, N.; Tabasizadeh, M. Optimization of the activity of KOH/calcium aluminate nanocatalyst for biodiesel production using response surface methodology. J. Taiwan Inst. Chem. Eng. 2016, 68, 379-386. [CrossRef]

113. Shi, M.; Zhang, P.; Fan, M.; Jiang, P.; Dong, Y. Influence of crystal of $\mathrm{Fe}_{2} \mathrm{O}_{3}$ in magnetism and activity of nanoparticle CaO@Fe $\mathrm{O}_{3}$ for biodiesel production. Fuel 2017, 197, 343-347. [CrossRef]

114. Hu, S.; Guan, Y.; Wang, Y.; Han, H. Nano-magnetic catalyst $\mathrm{KF} / \mathrm{CaO}-\mathrm{Fe}_{3} \mathrm{O}_{4}$ for biodiesel production. Appl. Energy 2011, 88, 2685-2690. [CrossRef]

115. Changmai, B.; Wheatley, A.E.H.; Rano, R.; Halder, G.; Selvaraj, M.; Rashid, U.; Rokhum, S.L. A magnetically separable acidfunctionalized nanocatalyst for biodiesel production. Fuel 2021, 305, 121576. [CrossRef]

116. Wu, Z.; Li, Z.; Wu, G.; Wang, L.; Lu, S.; Wang, L.; Wan, H.; Guan, G. Brønsted Acidic Ionic Liquid Modified Magnetic Nanoparticle: An Efficient and Green Catalyst for Biodiesel Production. Ind. Eng. Chem. Res. 2014, 53, 3040-3046. [CrossRef]

117. Xie, W.; Wang, H. Grafting copolymerization of dual acidic ionic liquid on core-shell structured magnetic silica: A magnetically recyclable Brönsted acid catalyst for biodiesel production by one-pot transformation of low-quality oils. Fuel 2021, 283, 118893. [CrossRef]

118. Qiu, F.; Li, Y.; Yang, D.; Li, X.; Sun, P. Heterogeneous solid base nanocatalyst: Preparation, characterization and application in biodiesel production. Bioresour. Technol. 2011, 102, 4150-4156. [CrossRef]

119. Ruhul, A.M.; Kalam, M.A.; Masjuki, H.H.; Alabdulkarem, A.; Atabani, A.E.; Fattah, I.M.R.; Abedin, M.J. Production, characterization, engine performance and emission characteristics of Croton megalocarpus and Ceiba pentandra complementary blends in a single-cylinder diesel engine. RSC Adv. 2016, 6, 24584-24595. [CrossRef]

120. Viriya-empikul, N.; Krasae, P.; Nualpaeng, W.; Yoosuk, B.; Faungnawakij, K. Biodiesel production over Ca-based solid catalysts derived from industrial wastes. Fuel 2012, 92, 239-244. [CrossRef]

121. Yang, L.; Zhang, A.; Zheng, X. Shrimp Shell Catalyst for Biodiesel Production. Energy Fuels 2009, 23, 3859-3865. [CrossRef]

122. Chakraborty, R.; Bepari, S.; Banerjee, A. Transesterification of soybean oil catalyzed by fly ash and egg shell derived solid catalysts. Chem. Eng. J. 2010, 165, 798-805. [CrossRef]

123. Lou, W.-Y.; Zong, M.-H.; Duan, Z.-Q. Efficient production of biodiesel from high free fatty acid-containing waste oils using various carbohydrate-derived solid acid catalysts. Bioresour. Technol. 2008, 99, 8752-8758. [CrossRef] [PubMed]

124. Shu, Q.; Zhang, Q.; Xu, G.; Nawaz, Z.; Wang, D.; Wang, J. Synthesis of biodiesel from cottonseed oil and methanol using a carbon-based solid acid catalyst. Fuel Process. Technol. 2009, 90, 1002-1008. [CrossRef]

125. Shu, Q.; Gao, J.; Nawaz, Z.; Liao, Y.; Wang, D.; Wang, J. Synthesis of biodiesel from waste vegetable oil with large amounts of free fatty acids using a carbon-based solid acid catalyst. Appl. Energy 2010, 87, 2589-2596. [CrossRef]

126. Pua, F.-1.; Fang, Z.; Zakaria, S.; Guo, F.; Chia, C.-h. Direct production of biodiesel from high-acid value Jatrophaoil with solid acid catalyst derived from lignin. Biotechnol. Biofuels 2011, 4, 56. [CrossRef] [PubMed]

127. Lou, W.-Y.; Guo, Q.; Chen, W.-J.; Zong, M.-H.; Wu, H.; Smith, T.J. A Highly Active Bagasse-Derived Solid Acid Catalyst with Properties Suitable for Production of Biodiesel. ChemSusChem 2012, 5, 1533-1541. [CrossRef]

128. Suryaputra, W.; Winata, I.; Indraswati, N.; Ismadji, S. Waste capiz (Amusium cristatum) shell as a new heterogeneous catalyst for biodiesel production. Renew. Energy 2013, 50, 795-799. [CrossRef]

129. Zhang, P.; Han, Q.; Fan, M.; Jiang, P. A novel waste water scale-derived solid base catalyst for biodiesel production. Fuel 2014, 124, 66-72. [CrossRef]

130. Gupta, A.R.; Rathod, V.K. Waste cooking oil and waste chicken eggshells derived solid base catalyst for the biodiesel production: Optimization and kinetics. Waste Manag. 2018, 79, 169-178. [CrossRef]

131. SIB Bioinformatics Resource Portal. ENZYME Class: 3.1.1. Available online: https://enzyme.expasy.org/EC/3.1.1.- (accessed on 14 September 2021).

132. Basumatary, B.; Basumatary, S.; Das, B.; Nath, B.; Kalita, P. Waste Musa paradisiaca plant: An efficient heterogeneous base catalyst for fast production of biodiesel. J. Clean. Prod. 2021, 305, 127089. [CrossRef]

133. Yuliana, M.; Santoso, S.P.; Soetaredjo, F.E.; Ismadji, S.; Ayucitra, A.; Gunarto, C.; Angkawijaya, A.E.; Ju, Y.-H.; Truong, C.-T. Efficient conversion of leather tanning waste to biodiesel using crab shell-based catalyst: WASTE-TO-ENERGY approach. Biomass Bioenergy 2021, 151, 106155. [CrossRef]

134. Deeba, F.; Kumar, B.; Arora, N.; Singh, S.; Kumar, A.; Han, S.S.; Negi, Y.S. Novel bio-based solid acid catalyst derived from waste yeast residue for biodiesel production. Renew. Energy 2020, 159, 127-139. [CrossRef]

135. Song, X.-L.; Fu, X.-B.; Zhang, C.-W.; Huang, W.-Y.; Zhu, Y.; Yang, J.; Zhang, Y.-M. Preparation of a Novel Carbon Based Solid Acid Catalyst for Biodiesel Production via a Sustainable Route. Catal. Lett. 2012, 142, 869-874. [CrossRef] 
136. Farabi, M.S.A.; Ibrahim, M.L.; Rashid, U.; Taufiq-Yap, Y.H. Esterification of palm fatty acid distillate using sulfonated carbon-based catalyst derived from palm kernel shell and bamboo. Energy Convers. Manag. 2019, 181, 562-570. [CrossRef]

137. Quah, R.V.; Tan, Y.H.; Mubarak, N.M.; Kansedo, J.; Khalid, M.; Abdullah, E.C.; Abdullah, M.O. Magnetic biochar derived from waste palm kernel shell for biodiesel production via sulfonation. Waste Manag. 2020, 118, 626-636. [CrossRef]

138. Gog, A.; Roman, M.; Toşa, M.; Paizs, C.; Irimie, F.D. Biodiesel production using enzymatic transesterification-Current state and perspectives. Renew. Energy 2012, 39, 10-16. [CrossRef]

139. Fattah, I.M.R.; Noraini, M.; Mofijur, M.; Silitonga, A.S.; Badruddin, I.A.; Khan, T.M.Y.; Ong, H.C.; Mahlia, T.M.I. Lipid Extraction Maximization and Enzymatic Synthesis of Biodiesel from Microalgae. Appl. Sci. 2020, 10, 6103. [CrossRef]

140. Moazeni, F.; Chen, Y.-C.; Zhang, G. Enzymatic transesterification for biodiesel production from used cooking oil, a review. J. Clean. Prod. 2019, 216, 117-128. [CrossRef]

141. Tang, W.; Wang, X.; Huang, J.; Jin, Q.; Wang, X. A novel method for the synthesis of symmetrical triacylglycerols by enzymatic transesterification. Bioresour. Technol. 2015, 196, 559-565. [CrossRef]

142. Costa, E.; Almeida, M.F.; Alvim-Ferraz, C.; Dias, J.M. Otimization of Crambe abyssinica enzymatic transesterification using response surface methodology. Renew. Energy 2021, 174, 444-452. [CrossRef]

143. Kumar, R.; Pal, P. Lipase immobilized graphene oxide biocatalyst assisted enzymatic transesterification of Pongamia pinnata (Karanja) oil and downstream enrichment of biodiesel by solar-driven direct contact membrane distillation followed by ultrafiltration. Fuel Process. Technol. 2021, 211, 106577. [CrossRef]

144. Makareviciene, V.; Gumbyte, M.; Sendzikiene, E. Simultaneous extraction of microalgae Ankistrodesmus sp. oil and enzymatic transesterification with ethanol in the mineral diesel medium. Food Bioprod. Process. 2019, 116, 89-97. [CrossRef]

145. Aarthy, M.; Saravanan, P.; Gowthaman, M.K.; Rose, C.; Kamini, N.R. Enzymatic transesterification for production of biodiesel using yeast lipases: An overview. Chem. Eng. Res. 2014, 92, 1591-1601. [CrossRef]

146. Lopresto, C.G.; Naccarato, S.; Albo, L.; De Paola, M.G.; Chakraborty, S.; Curcio, S.; Calabrò, V. Enzymatic transesterification of waste vegetable oil to produce biodiesel. Ecotoxicol. Environ. Saf. 2015, 121, 229-235. [CrossRef] [PubMed]

147. Goujard, L.; Ferre, E.; Gil, G.; Ruaudel, F.; Farnet, A.M. A method to quantify transesterification activities of lipases in litters. J. Microbiol. Methods 2009, 78, 127-130. [CrossRef] [PubMed]

148. Diego, T.D.; Manjón, A.; Lozano, P.; Iborra, J.L. A recyclable enzymatic biodiesel production process in ionic liquids. Bioresour. Technol. 2011, 102, 6336-6339. [CrossRef] [PubMed]

149. Fjerbaek, L.; Christensen, K.V.; Norddahl, B. A review of the current state of biodiesel production using enzymatic transesterification. Biotechnol. Bioeng. 2009, 102, 1298-1315. [CrossRef]

150. Hama, S.; Kondo, A. Enzymatic biodiesel production: An overview of potential feedstocks and process development. Bioresour. Technol. 2013, 135, 386-395. [CrossRef]

151. Ranganathan, S.V.; Narasimhan, S.L.; Muthukumar, K. An overview of enzymatic production of biodiesel. Bioresour. Technol. 2008, 99, 3975-3981. [CrossRef] [PubMed]

152. dos Reis-Costa, L.; Andreimar, M.S.; Suzelei, C.F.; Henrique, C.T.; Timothy John, C.R. Immobilization of Lipases And Assay in Continuous Fixed Bed Reactor. Protein Pept. Lett. 2003, 10, 619-628. [CrossRef]

153. Yadav, G.D.; Devi, K.M. Immobilized lipase-catalysed esterification and transesterification reactions in non-aqueous media for the synthesis of tetrahydrofurfuryl butyrate: Comparison and kinetic modeling. Chem. Eng. Sci. 2004, 59, 373-383. [CrossRef]

154. Akoh, C.C.; Chang, S.-W.; Lee, G.-C.; Shaw, J.-F. Enzymatic Approach to Biodiesel Production. J. Agric. Food Chem. 2007, 55, 8995-9005. [CrossRef]

155. Zeng, H.-Y.; Liao, K.-B.; Deng, X.; Jiang, H.; Zhang, F. Characterization of the lipase immobilized on Mg-Al hydrotalcite for biodiesel. Process Biochem. 2009, 44, 791-798. [CrossRef]

156. Li, A.; Ngo, T.P.N.; Yan, J.; Tian, K.; Li, Z. Whole-cell based solvent-free system for one-pot production of biodiesel from waste grease. Bioresour. Technol. 2012, 114, 725-729. [CrossRef]

157. Zhang, K.-P.; Lai, J.-Q.; Huang, Z.-L.; Yang, Z. Penicillium expansum lipase-catalyzed production of biodiesel in ionic liquids. Bioresour. Technol. 2011, 102, 2767-2772. [CrossRef]

158. Atadashi, I.M.; Aroua, M.K.; Abdul Aziz, A.R.; Sulaiman, N.M.N. The effects of water on biodiesel production and refining technologies: A review. Renew. Sustain. Energy Rev. 2012, 16, 3456-3470. [CrossRef]

159. Véras, I.C.; Silva, F.A.L.; Ferrão-Gonzales, A.D.; Moreau, V.H. One-step enzymatic production of fatty acid ethyl ester from high-acidity waste feedstocks in solvent-free media. Bioresour. Technol. 2011, 102, 9653-9658. [CrossRef] [PubMed]

160. Shah, S.; Gupta, M.N. Lipase catalyzed preparation of biodiesel from Jatropha oil in a solvent free system. Process Biochem. 2007, 42, 409-414. [CrossRef]

161. Wang, L.; Du, W.; Liu, D.; Li, L.; Dai, N. Lipase-catalyzed biodiesel production from soybean oil deodorizer distillate with absorbent present in tert-butanol system. J. Mol. Catal. B Enzym. 2006, 43, 29-32. [CrossRef]

162. Lai, C.-C.; Zullaikah, S.; Vali, S.R.; Ju, Y.-H. Lipase-catalyzed production of biodiesel from rice bran oil. J. Chem. Technol. Biotechnol. 2005, 80, 331-337. [CrossRef]

163. Soumanou, M.M.; Bornscheuer, U.T. Improvement in lipase-catalyzed synthesis of fatty acid methyl esters from sunflower oil. Enzym. Microb. Technol. 2003, 33, 97-103. [CrossRef]

164. Shimada, Y.; Watanabe, Y.; Samukawa, T.; Sugihara, A.; Noda, H.; Fukuda, H.; Tominaga, Y. Conversion of vegetable oil to biodiesel using immobilized Candida antarctica lipase. J. Am. Oil Chem. Soc. 1999, 76, 789-793. [CrossRef] 
165. Chen, J.-W.; Wu, W.-T. Regeneration of immobilized Candida antarctica lipase for transesterification. J. Biosci. Bioeng. 2003, 95, 466-469. [CrossRef]

166. Lu, J.; Deng, L.; Zhao, R.; Zhang, R.; Wang, F.; Tan, T. Pretreatment of immobilized Candida sp. 99-125 lipase to improve its methanol tolerance for biodiesel production. J. Mol. Catal. B Enzym. 2010, 62, 15-18. [CrossRef]

167. Rodrigues, R.C.; Volpato, G.; Wada, K.; Ayub, M.A.Z. Enzymatic Synthesis of Biodiesel from Transesterification Reactions of Vegetable Oils and Short Chain Alcohols. J. Am. Oil Chem. Soc. 2008, 85, 925-930. [CrossRef]

168. Hama, S.; Tamalampudi, S.; Yoshida, A.; Tamadani, N.; Kuratani, N.; Noda, H.; Fukuda, H.; Kondo, A. Enzymatic packed-bed reactor integrated with glycerol-separating system for solvent-free production of biodiesel fuel. Biochem. Eng. J. 2011, 55, 66-71. [CrossRef]

169. Hama, S.; Tamalampudi, S.; Yoshida, A.; Tamadani, N.; Kuratani, N.; Noda, H.; Fukuda, H.; Kondo, A. Process engineering and optimization of glycerol separation in a packed-bed reactor for enzymatic biodiesel production. Bioresour. Technol. 2011, 102, 10419-10424. [CrossRef] [PubMed]

170. Xu, Y.; Nordblad, M.; Nielsen, P.M.; Brask, J.; Woodley, J.M. In situ visualization and effect of glycerol in lipase-catalyzed ethanolysis of rapeseed oil. J. Mol. Catal. B Enzym. 2011, 72, 213-219. [CrossRef]

171. Stevenson, D.E.; Stanley, R.A.; Furneaux, R.H. Near-quantitative production of fatty acid alkyl esters by lipase-catalyzed alcoholysis of fats and oils with adsorption of glycerol by silica gel. Enzym. Microb. Technol. 1994, 16, 478-484. [CrossRef]

172. Halim, S.F.A.; Harun Kamaruddin, A. Catalytic studies of lipase on FAME production from waste cooking palm oil in a tert-butanol system. Process Biochem. 2008, 43, 1436-1439. [CrossRef]

173. Royon, D.; Daz, M.; Ellenrieder, G.; Locatelli, S. Enzymatic production of biodiesel from cotton seed oil using t-butanol as a solvent. Bioresour. Technol. 2007, 98, 648-653. [CrossRef] [PubMed]

174. Li, L.; Du, W.; Liu, D.; Wang, L.; Li, Z. Lipase-catalyzed transesterification of rapeseed oils for biodiesel production with a novel organic solvent as the reaction medium. J. Mol. Catal. B Enzym. 2006, 43, 58-62. [CrossRef]

175. Tang, S.; Jones, C.L.; Zhao, H. Glymes as new solvents for lipase activation and biodiesel preparation. Bioresour. Technol. 2013, 129, 667-671. [CrossRef]

176. Kim, K.-W.; Song, B.; Choi, M.-Y.; Kim, M.-J. Biocatalysis in Ionic Liquids: Markedly Enhanced Enantioselectivity of Lipase. Org. Lett. 2001, 3, 1507-1509. [CrossRef]

177. Park, S.; Kazlauskas, R.J. Biocatalysis in ionic liquids-advantages beyond green technology. Curr. Opin. Biotechnol. 2003, 14, 432-437. [CrossRef]

178. Arai, S.; Nakashima, K.; Tanino, T.; Ogino, C.; Kondo, A.; Fukuda, H. Production of biodiesel fuel from soybean oil catalyzed by fungus whole-cell biocatalysts in ionic liquids. Enzym. Microb. Technol. 2010, 46, 51-55. [CrossRef]

179. Sunitha, S.; Kanjilal, S.; Reddy, P.S.; Prasad, R.B. Ionic liquids as a reaction medium for lipase-catalyzed methanolysis of sunflower oil. Biotechnol. Lett. 2007, 29, 1881-1885. [CrossRef]

180. Lai, J.-Q.; Hu, Z.-L.; Wang, P.-W.; Yang, Z. Enzymatic production of microalgal biodiesel in ionic liquid [BMIm][PF6]. Fuel 2012, 95, 329-333. [CrossRef]

181. Fan, Y.; Qian, J. Lipase catalysis in ionic liquids/supercritical carbon dioxide and its applications. J. Mol. Catal. B Enzym. 2010, 66, 1-7. [CrossRef]

182. Lozano, P.; De Diego, T.; Vaultier, M.; Iborra, J.L. Enzyme Catalysis in Ionic Liquids and Supercritical Carbon Dioxide. In Ionic Liquid Applications: Pharmaceuticals, Therapeutics, and Biotechnology; American Chemical Society: Washington, DC, USA, 2010; Volume 1038, pp. 181-196.

183. Durand, E.; Lecomte, J.; Baréa, B.; Piombo, G.; Dubreucq, E.; Villeneuve, P. Evaluation of deep eutectic solvents as new media for Candida antarctica B lipase catalyzed reactions. Process Biochem. 2012, 47, 2081-2089. [CrossRef]

184. Zhao, H.; Baker, G.A.; Holmes, S. New eutectic ionic liquids for lipase activation and enzymatic preparation of biodiesel. Org. Biomol. Chem. 2011, 9, 1908-1916. [CrossRef]

185. Du, W.; Xu, Y.; Liu, D.; Zeng, J. Comparative study on lipase-catalyzed transformation of soybean oil for biodiesel production with different acyl acceptors. J. Mol. Catal. B Enzym. 2004, 30, 125-129. [CrossRef]

186. Ognjanovic, N.; Bezbradica, D.; Knezevic-Jugovic, Z. Enzymatic conversion of sunflower oil to biodiesel in a solvent-free system: Process optimization and the immobilized system stability. Bioresour. Technol. 2009, 100, 5146-5154. [CrossRef] [PubMed]

187. Talukder, M.M.R.; Wu, J.C.; Fen, N.M.; Melissa, Y.L.S. Two-step lipase catalysis for production of biodiesel. Biochem. Eng. J. 2010, 49, 207-212. [CrossRef]

188. Meng, Y.; Wang, G.; Yang, N.; Zhou, Z.; Li, Y.; Liang, X.; Chen, J.; Li, Y.; Li, J. Two-step synthesis of fatty acid ethyl ester from soybean oil catalyzed by Yarrowia lipolytica lipase. Biotechnol. Biofuels 2011, 4, 6. [CrossRef]

189. Gao, S.; Wang, Y.; Wang, T.; Luo, G.; Dai, Y. Immobilization of lipase on methyl-modified silica aerogels by physical adsorption. Bioresour. Technol. 2009, 100, 996-999. [CrossRef]

190. Abdul Rahman, M.B.; Tajudin, S.M.; Hussein, M.Z.; Abdul Rahman, R.N.Z.R.; Salleh, A.B.; Basri, M. Application of natural kaolin as support for the immobilization of lipase from Candida rugosa as biocatalsyt for effective esterification. Appl. Clay Sci. 2005, 29, 111-116. [CrossRef]

191. Gao, Y.; Tan, T.-W.; Nie, K.-L.; Wang, F. Immobilization of Lipase on Macroporous Resin and Its Application in Synthesis of Biodiesel in Low Aqueous Media. Chin. J. Biotechnol. 2006, 22, 114-118. [CrossRef] 
192. Sakai, S.; Liu, Y.; Yamaguchi, T.; Watanabe, R.; Kawabe, M.; Kawakami, K. Production of butyl-biodiesel using lipase physicallyadsorbed onto electrospun polyacrylonitrile fibers. Bioresour. Technol. 2010, 101, 7344-7349. [CrossRef] [PubMed]

193. Dizge, N.; Keskinler, B.; Tanriseven, A. Covalent attachment of microbial lipase onto microporous styrene-divinylbenzene copolymer by means of polyglutaraldehyde. Colloids Surf. B Biointerfaces 2008, 66, 34-38. [CrossRef] [PubMed]

194. Knezevic, Z.; Milosavic, N.; Bezbradica, D.; Jakovljevic, Z.; Prodanovic, R. Immobilization of lipase from Candida rugosa on Eupergit ${ }^{\circledR} C$ supports by covalent attachment. Biochem. Eng. J. 2006, 30, 269-278. [CrossRef]

195. Silva, G.A.M.; Da Rós, P.C.M.; Souza, L.T.A.; Costa, A.P.O.; de Castro, H.F. Physico-chemical, spectroscopical and thermal characterization of biodiesel obtained by enzymatic route as a tool to select the most efficient immobilized lipase. Braz. J. Chem. Eng. 2012, 29, 39-47. [CrossRef]

196. Bhushan, I.; Parshad, R.; Qazi, G.N.; Gupta, V.K. Immobilization of Lipase by Entrapment in Ca-alginate Beads. J. Bioact. Compat. Polym. 2008, 23, 552-562. [CrossRef]

197. Hsu, A.-F.; Jones, K.C.; Foglia, T.A.; Marmer, W.N. Transesterification activity of lipases immobilized in a phyllosilicate sol-gel matrix. Biotechnol. Lett. 2004, 26, 917-921. [CrossRef] [PubMed]

198. Noureddini, H.; Gao, X.; Philkana, R.S. Immobilized Pseudomonas cepacia lipase for biodiesel fuel production from soybean oil. Bioresour. Technol. 2005, 96, 769-777. [CrossRef]

199. Sawangpanya, N.; Muangchim, C.; Phisalaphong, M. Immobilization of lipase on $\mathrm{CaCO}_{3}$ and entrapment in calcium alginate bead for biodiesel production. Sci. J. Ubon Ratchathani Univ. 2010, 1, 46-51.

200. Jegannathan, K.R.; Jun-Yee, L.; Chan, E.-S.; Ravindra, P. Production of biodiesel from palm oil using liquid core lipase encapsulated in K-carrageenan. Fuel 2010, 89, 2272-2277. [CrossRef]

201. Macario, A.; Moliner, M.; Corma, A.; Giordano, G. Increasing stability and productivity of lipase enzyme by encapsulation in a porous organic-inorganic system. Microporous Mesoporous Mater. 2009, 118, 334-340. [CrossRef]

202. Dizge, N.; Keskinler, B. Enzymatic production of biodiesel from canola oil using immobilized lipase. Biomass Bioenergy 2008, 32, 1274-1278. [CrossRef]

203. Lai, J.-Q.; Hu, Z.-L.; Sheldon, R.A.; Yang, Z. Catalytic performance of cross-linked enzyme aggregates of Penicillium expansum lipase and their use as catalyst for biodiesel production. Process Biochem. 2012, 47, 2058-2063. [CrossRef]

204. Yan, J.; Yan, Y.; Liu, S.; Hu, J.; Wang, G. Preparation of cross-linked lipase-coated micro-crystals for biodiesel production from waste cooking oil. Bioresour. Technol. 2011, 102, 4755-4758. [CrossRef]

205. Shu, C.; Cai, J.; Huang, L.; Zhu, X.; Xu, Z. Biocatalytic production of ethyl butyrate from butyric acid with immobilized Candida rugosa lipase on cotton cloth. J. Mol. Catal. B Enzym. 2011, 72, 139-144. [CrossRef]

206. Yücel, Y. Biodiesel production from pomace oil by using lipase immobilized onto olive pomace. Bioresour. Technol. 2011, 102, 3977-3980. [CrossRef] [PubMed]

207. Charuchinda, S.; Suthianthong, P.; Chulalaksananukul, W. Immobilization of lipase onto Cyperus Papyrus L. for biodiesel production by transesterification and hydrolysis-esterification. J. Metals Mater. Miner. 2011, 21, 127-133.

208. Oda, M.; Kaieda, M.; Hama, S.; Yamaji, H.; Kondo, A.; Izumoto, E.; Fukuda, H. Facilitatory effect of immobilized lipase-producing Rhizopus oryzae cells on acyl migration in biodiesel-fuel production. Biochem. Eng. J. 2005, 23, 45-51. [CrossRef]

209. Tamalampudi, S.; Talukder, M.R.; Hama, S.; Numata, T.; Kondo, A.; Fukuda, H. Enzymatic production of biodiesel from Jatropha oil: A comparative study of immobilized-whole cell and commercial lipases as a biocatalyst. Biochem. Eng. J. 2008, 39, 185-189. [CrossRef]

210. Tan, S.X.; Lim, S.; Ong, H.C.; Pang, Y.L. State of the art review on development of ultrasound-assisted catalytic transesterification process for biodiesel production. Fuel 2019, 235, 886-907. [CrossRef]

211. Chengareddy, P.; Arumugam, S.; Reddy, P.P.K.; Reddy, P.M.M. A Review on Ultrasonicated Transesterification Process. In Advances in Materials and Manufacturing Engineering; Springer Nature Singapore Pte. Ltd.: Singapore, 2021; pp. 579-585.

212. Gusniah, A.; Veny, H.; Hamzah, F. Ultrasonic Assisted Enzymatic Transesterification for Biodiesel Production. Ind. Eng. Chem. Res. 2019, 58, 581-589. [CrossRef]

213. Ramachandran, K.; Suganya, T.; Nagendra Gandhi, N.; Renganathan, S. Recent developments for biodiesel production by ultrasonic assist transesterification using different heterogeneous catalyst: A review. Renew. Sustain. Energy Rev. 2013, 22, 410-418. [CrossRef]

214. Teixeira, L.S.G.; Assis, J.C.R.; Mendonça, D.R.; Santos, I.T.V.; Guimarães, P.R.B.; Pontes, L.A.M.; Teixeira, J.S.R. Comparison between conventional and ultrasonic preparation of beef tallow biodiesel. Fuel Process. Technol. 2009, 90, 1164-1166. [CrossRef]

215. Kumar, D.; Kumar, G.; Singh, C.P. Fast, easy ethanolysis of coconut oil for biodiesel production assisted by ultrasonication. Ultrason. Sonochem. 2010, 17, 555-559. [CrossRef]

216. Hingu, S.M.; Gogate, P.R.; Rathod, V.K. Synthesis of biodiesel from waste cooking oil using sonochemical reactors. Ultrason. Sonochem. 2010, 17, 827-832. [CrossRef]

217. Deng, X.; Fang, Z.; Liu, Y.-H. Ultrasonic transesterification of Jatropha curcas L. oil to biodiesel by a two-step process. Energy Convers. Manag. 2010, 51, 2802-2807. [CrossRef]

218. Batistella, L.; Lerin, L.A.; Brugnerotto, P.; Danielli, A.J.; Trentin, C.M.; Popiolski, A.; Treichel, H.; Oliveira, J.V.; de Oliveira, D. Ultrasound-assisted lipase-catalyzed transesterification of soybean oil in organic solvent system. Ultrason. Sonochem. 2012, 19, 452-458. [CrossRef] [PubMed] 
219. Nayak, S.N.; Bhasin, C.P.; Nayak, M.G. A review on microwave-assisted transesterification processes using various catalytic and non-catalytic systems. Renew. Energy 2019, 143, 1366-1387. [CrossRef]

220. Fazril, I.; Shamsuddin, A.H.; Nomanbhay, S.; Kusomo, F.; Hanif, M.; Ahmad Zamri, M.F.M.; Akhiar, A.; Ismail, M.F. Microwaveassisted in situ transesterification of wet microalgae for the production of biodiesel: Progress review. IOP Conf. Ser. Earth Environ. Sci. 2020, 476, 012078. [CrossRef]

221. Mohamad Aziz, N.A.; Yunus, R.; Kania, D.; Abd Hamid, H. Prospects and Challenges of Microwave-Combined Technology for Biodiesel and Biolubricant Production through a Transesterification: A Review. Molecules 2021, 26, 788. [CrossRef]

222. Azcan, N.; Danisman, A. Alkali catalyzed transesterification of cottonseed oil by microwave irradiation. Fuel 2007, 86, 2639-2644. [CrossRef]

223. Perin, G.; Álvaro, G.; Westphal, E.; Viana, L.H.; Jacob, R.G.; Lenardão, E.J.; D'Oca, M.G.M. Transesterification of castor oil assisted by microwave irradiation. Fuel 2008, 87, 2838-2841. [CrossRef]

224. Hsiao, M.-C.; Lin, C.-C.; Chang, Y.-H.; Chen, L.-C. Ultrasonic mixing and closed microwave irradiation-assisted transesterification of soybean oil. Fuel 2010, 89, 3618-3622. [CrossRef]

225. Gole, V.L.; Gogate, P.R. Intensification of synthesis of biodiesel from non-edible oil using sequential combination of microwave and ultrasound. Fuel Process. Technol. 2013, 106, 62-69. [CrossRef]

226. Singh, C.S.; Kumar, N.; Gautam, R. Supercritical transesterification route for biodiesel production: Effect of parameters on yield and future perspectives. Environ. Progress Sustain. Energy 2021, e13685. [CrossRef]

227. Qadeer, M.U.; Ayoub, M.; Komiyama, M.; Khan Daulatzai, M.U.; Mukhtar, A.; Saqib, S.; Ullah, S.; Qyyum, M.A.; Asif, S.; Bokhari, A. Review of biodiesel synthesis technologies, current trends, yield influencing factors and economical analysis of supercritical process. J. Clean. Prod. 2021, 309, 127388. [CrossRef]

228. Karki, S.; Sanjel, N.; Poudel, J.; Choi, J.H.; Oh, S.C. Supercritical Transesterification of Waste Vegetable Oil: Characteristic Comparison of Ethanol and Methanol as Solvents. Appl. Sci. 2017, 7, 632. [CrossRef]

229. Saka, S.; Kusdiana, D.; Minami, E. Non-catalytic biodiesel production with supercritical methanol technologies. J. Sci. Ind. Res. 2006, 65, 420-425.

230. Tan, K.T.; Lee, K.T. A review on supercritical fluids (SCF) technology in sustainable biodiesel production: Potential and challenges. Renew. Sustain. Energy Rev. 2011, 15, 2452-2456. [CrossRef]

231. Ahmad, N.; Abnisa, F.; Daud, W.M.A.W. Synthesis of valuable intermediate products from natural rubber under supercritical alcohol conditions. Appl. Pyrolysis 2019, 139, 196-204. [CrossRef]

232. Tang, Z.; Wang, Y.; Chen, M.; Zhang, J.; Wang, C.; Yang, Z.; Zhang, H.; Wang, J. Study of Mo-based sepiolite catalyst on depolymerization of lignin under supercritical ethanol. Energy Res. 2020, 44, 257-268. [CrossRef]

233. Wen, D.; Jiang, H.; Zhang, K. Supercritical fluids technology for clean biofuel production. Progress Natl. Sci. 2009, 19, $273-284$. [CrossRef]

234. Yujaroen, D.; Goto, M.; Sasaki, M.; Shotipruk, A. Esterification of palm fatty acid distillate (PFAD) in supercritical methanol: Effect of hydrolysis on reaction reactivity. Fuel 2009, 88, 2011-2016. [CrossRef]

235. Patil, P.D.; Gude, V.G.; Mannarswamy, A.; Deng, S.; Cooke, P.; Munson-McGee, S.; Rhodes, I.; Lammers, P.; Nirmalakhandan, N. Optimization of direct conversion of wet algae to biodiesel under supercritical methanol conditions. Bioresour. Technol. 2011, 102, 118-122. [CrossRef] [PubMed]

236. Saka, S.; Isayama, Y.; Ilham, Z.; Jiayu, X. New process for catalyst-free biodiesel production using subcritical acetic acid and supercritical methanol. Fuel 2010, 89, 1442-1446. [CrossRef]

237. Saka, S.; Kusdiana, D. Biodiesel fuel from rapeseed oil as prepared in supercritical methanol. Fuel 2001, 80, 225-231. [CrossRef]

238. Kusdiana, D.; Saka, S. Kinetics of transesterification in rapeseed oil to biodiesel fuel as treated in supercritical methanol. Fuel 2001, 80, 693-698. [CrossRef]

239. Warabi, Y.; Kusdiana, D.; Saka, S. Reactivity of triglycerides and fatty acids of rapeseed oil in supercritical alcohols. Bioresour. Technol. 2004, 91, 283-287. [CrossRef]

240. Madras, G.; Kolluru, C.; Kumar, R. Synthesis of biodiesel in supercritical fluids. Fuel 2004, 83, 2029-2033. [CrossRef]

241. He, H.; Wang, T.; Zhu, S. Continuous production of biodiesel fuel from vegetable oil using supercritical methanol process. Fuel 2007, 86, 442-447. [CrossRef]

242. Hawash, S.; Kamal, N.; Zaher, F.; Kenawi, O.; Diwani, G.E. Biodiesel fuel from Jatropha oil via non-catalytic supercritical methanol transesterification. Fuel 2009, 88, 579-582. [CrossRef]

243. Demirbas, A. Biodiesel from waste cooking oil via base-catalytic and supercritical methanol transesterification. Energy Convers. Manag. 2009, 50, 923-927. [CrossRef]

244. Santana, A.; Maçaira, J.; Larrayoz, M.A. Continuous production of biodiesel from vegetable oil using supercritical ethanol/carbon dioxide mixtures. Fuel Process. Technol. 2012, 96, 214-219. [CrossRef]

245. Micic, R.D.; Tomić, M.D.; Kiss, F.E.; Nikolić-Djorić, E.B.; Simikić, M.Đ. Influence of reaction conditions and type of alcohol on biodiesel yields and process economics of supercritical transesterification. Energy Convers. Manag. 2014, 86, 717-726. [CrossRef]

246. Kusdiana, D.; Saka, S. Effects of water on biodiesel fuel production by supercritical methanol treatment. Bioresour. Technol. 2004, 91, 289-295. [CrossRef]

247. Hegel, P.E.; Martín, L.A.; Popovich, C.A.; Damiani, C.; Leonardi, P.I. Biodiesel production from Halamphora coffeaeformis microalga oil by supercritical ethanol transesterification. Chem. Eng. Process.-Process Intensif. 2019, 145, 107670. [CrossRef] 
248. Saka, S.; Isayama, Y. A new process for catalyst-free production of biodiesel using supercritical methyl acetate. Fuel 2009, 88 , 1307-1313. [CrossRef]

249. Patil, P.D.; Reddy, H.; Muppaneni, T.; Deng, S. Biodiesel fuel production from algal lipids using supercritical methyl acetate (glycerin-free) technology. Fuel 2017, 195, 201-207. [CrossRef]

250. Tan, K.T.; Lee, K.T.; Mohamed, A.R. Prospects of non-catalytic supercritical methyl acetate process in biodiesel production. Fuel Process. Technol. 2011, 92, 1905-1909. [CrossRef]

251. Ilham, Z.; Saka, S. Dimethyl carbonate as potential reactant in non-catalytic biodiesel production by supercritical method. Bioresour. Technol. 2009, 100, 1793-1796. [CrossRef] [PubMed]

252. Li, D.; Wang, W.; Durrani, R.; Li, X.; Yang, B.; Wang, Y. Simplified Enzymatic Upgrading of High-Acid Rice Bran Oil Using Ethanol as a Novel Acyl Acceptor. J. Agric. Food Chem. 2016, 64, 6730-6737. [CrossRef]

253. Li, D.; Liu, P.; Wang, W.; Wang, X.; Yang, B.; Wang, Y. An Innovative Deacidification Approach for Producing Partial GlyceridesFree Rice Bran Oil. Food Bioprocess Technol. 2017, 10, 1154-1161. [CrossRef]

254. Sun, S.; Guo, J.; Duan, X. Biodiesel preparation from Phoenix tree seed oil using ethanol as acyl acceptor. Ind. Crops Prod. 2019, 137, 270-275. [CrossRef]

255. Li, D.; Faiza, M.; Ali, S.; Wang, W.; Tan, C.P.; Yang, B.; Wang, Y. Highly Efficient Deacidification of High-Acid Rice Bran Oil Using Methanol as a Novel Acyl Acceptor. Appl. Biochem. Biotechnol. 2018, 184, 1061-1072. [CrossRef] [PubMed]

256. Imahara, H.; Minami, E.; Hari, S.; Saka, S. Thermal stability of biodiesel in supercritical methanol. Fuel 2008, 87, 1-6. [CrossRef]

257. Yin, J.-Z.; Ma, Z.; Shang, Z.-Y.; Hu, D.-P.; Xiu, Z.-L. Biodiesel production from soybean oil transesterification in subcritical methanol with K3PO4 as a catalyst. Fuel 2012, 93, 284-287. [CrossRef]

258. Demirbas, A. Biodiesel from sunflower oil in supercritical methanol with calcium oxide. Energy Convers. Manag. 2007, 48, 937-941. [CrossRef]

259. Yin, J.-Z.; Xiao, M.; Wang, A.-Q.; Xiu, Z.-L. Synthesis of biodiesel from soybean oil by coupling catalysis with subcritical methanol. Energy Convers. Manag. 2008, 49, 3512-3516. [CrossRef]

260. Kusdiana, D.; Saka, S. Two-step preparation for catalyst-free biodiesel fuel production. Appl. Biochem. Biotechnol. 2004, 115, 781-791. [CrossRef]

261. Minami, E.; Saka, S. Kinetics of hydrolysis and methyl esterification for biodiesel production in two-step supercritical methanol process. Fuel 2006, 85, 2479-2483. [CrossRef]

262. Ilham, Z.; Saka, S. Two-step supercritical dimethyl carbonate method for biodiesel production from Jatropha curcas oil. Bioresour. Technol. 2010, 101, 2735-2740. [CrossRef] [PubMed]

263. Kim, B.; Heo, H.Y.; Son, J.; Yang, J.; Chang, Y.-K.; Lee, J.H.; Lee, J.W. Simplifying biodiesel production from microalgae via wet in situ transesterification: A review in current research and future prospects. Algal Res. 2019, 41, 101557. [CrossRef]

264. Makareviciene, V.; Sendzikiene, E.; Gumbyte, M. Application of Simultaneous Oil Extraction and Transesterification in Biodiesel Fuel Synthesis: A Review. Energies 2020, 13, 2204. [CrossRef]

265. Sendzikiene, E.; Santaraite, M.; Makareviciene, V. Lipase-Catalysed In Situ Transesterification of Waste Rapeseed Oil to Produce Diesel-Biodiesel Blends. Processes 2020, 8, 1118. [CrossRef]

266. Haas, M.J.; Scott, K.M.; Marmer, W.N.; Foglia, T.A. In situ alkaline transesterification: An effective method for the production of fatty acid esters from vegetable oils. J. Am. Oil Chem. Soc. 2004, 81, 83-89. [CrossRef]

267. Qian, J.; Wang, F.; Liu, S.; Yun, Z. In situ alkaline transesterification of cottonseed oil for production of biodiesel and nontoxic cottonseed meal. Bioresour. Technol. 2008, 99, 9009-9012. [CrossRef]

268. Shuit, S.H.; Lee, K.T.; Kamaruddin, A.H.; Yusup, S. Reactive extraction and in situ esterification of Jatropha curcas L. seeds for the production of biodiesel. Fuel 2010, 89, 527-530. [CrossRef]

269. Ehimen, E.A.; Sun, Z.F.; Carrington, C.G. Variables affecting the in situ transesterification of microalgae lipids. Fuel 2010, 89, 677-684. [CrossRef]

270. Su, E.-Z.; Xu, W.-Q.; Gao, K.-L.; Zheng, Y.; Wei, D.-Z. Lipase-catalyzed in situ reactive extraction of oilseeds with short-chained alkyl acetates for fatty acid esters production. J. Mol. Catal. B Enzym. 2007, 48, 28-32. [CrossRef]

271. Su, E.; You, P.; Wei, D. In situ lipase-catalyzed reactive extraction of oilseeds with short-chained dialkyl carbonates for biodiesel production. Bioresour. Technol. 2009, 100, 5813-5817. [CrossRef] [PubMed]

272. Lim, S.; Hoong, S.S.; Teong, L.K.; Bhatia, S. Supercritical fluid reactive extraction of Jatropha curcas L. seeds with methanol: A novel biodiesel production method. Bioresour. Technol. 2010, 101, 7169-7172. [CrossRef] [PubMed] 